Article

\title{
Review of the Hygrophilous Weevils in Israel (Coleoptera: Curculionoidea)
}

\author{
Ariel-Leib-Leonid Friedman
}

The Steinhardt Museum of Natural History and Israel National Center for Biodiversity Studies, School of Zoology, Tel Aviv University, Tel Aviv 69978, Israel; laibale@post.tau.ac.il; Tel.: +972-54-235-8022

Received: 20 June 2018; Accepted: 26 July 2018; Published: 31 July 2018

\begin{abstract}
Forty-one species in 20 genera of hygrophilous weevils belonging to Brentidae and Curculionidae, associated with inland aquatic habitats, have been recorded recently from Israel, eight of them for the first time. Thirty-four species are extant, while five species have probably become extinct recently, and two are fossil species, known from Late Cretaceous deposits. Sixteen species are either aquatic or semi-aquatic, while the rest occur only or predominantly on riparian vegetation. Distributional and biological data for most of the species are provided. A key to all hygrophilous weevil taxa and illustrations for most of the species are provided.
\end{abstract}

Keywords: Curculionoidea; weevil; hygrophilous; aquatic; semi-aquatic; riparian; key; Israel

\section{Introduction}

Weevils are the largest monophyletic group of beetles, comprising more than 62,000 described species [1]. Only a minority of these are aquatic or semi-aquatic, and completely aquatic species comprise less than $1 \%$ of the weevil world fauna [2]. Most of the aquatic weevils inhabit inland freshwater habitats, although there are some weevil taxa (mainly Cossoninae) that inhabit the supratidal zone (splash zone) and develop on marine algae driven ashore [3] or on timber floating in seawater [4-6]. Many weevil species, albeit not directly associated with water, occur mainly or predominantly in wetlands, near or above the water, primarily because their host plants are hygrophilous. This is especially noticeable in semi-arid countries with a dry climate, like Israel. Completely aquatic and semi-aquatic weevils are confined to standing water or to water with a very slow current, and are therefore mostly found in lakes, swamps, ponds, floodplains, or eddies of slow-moving rivers or in artificial or temporary ponds [7]. Those hygrophilous weevils that are not aquatic are less limited in their distribution and can be found adjacent to any water body of considerable size, with either standing or flowing water, if their host plants are available.

One of the earliest geographical descriptions of the Land of Israel, in the Book of Deuteronomy (8:7), refers to it as "a land with brooks, streams, and deep springs gushing out in the valleys and mountains." The current State of Israel [8] (matching partly the historical Land of Israel) is a country encompassing a Mediterranean-type, as well as semi-arid and arid climatic zones (Figure 17). A rapid rainfall gradient spreads along less than $450 \mathrm{~km}$, from almost $1000 \mathrm{~mm}$ in the north to barely $20 \mathrm{~mm}$ in the south [9]. The northern part of the country (Galilee, Golan Heights, Upper Jordan Valley, Yizre'el (=Jezreel) Valley, Carmel Ridge), and the coastal plain and western slopes of the Samarian and Judean Hills possess typical Mediterranean vegetation (phrygana and batha), while the southern part (Negev Desert), eastern slopes of the Samarian and Judean Hills (Samarian and Judean Deserts) and the southern part of the Jordan Valley, Dead Sea Area and Arava Valley are semi-deserts or deserts with either steppe type (at higher altitudes) or eremic type vegetation. The coastal plain is fringed by a strip of sand dunes, wider in the southern part and tapering northwards, which in the past played an important role in the formation of the coastal swamps. 
In spite of the arid nature of its climate, Israel possesses numerous and varied aquatic biotopes. Its inland water system is affected by the complex geological history of the area. Most of the country lies on the western slope of the northernmost tip of the Rift Valley. The water systems are therefore divided longitudinally by the Galilee mountains and Samarian and Judean Hills into the coastal system in the west, including approximately 15 streams flowing into the Mediterranean Sea, and the Rift Valley itself in the east, subdivided into the Jordan Valley (Jordan River, its tributaries, the Hula Lake, and Lake Kinneret) and the Dead Sea with its tributaries. The coastal and the Jordan Valley systems were partially connected until the second half of the 20th century by the low Yizre'el Valley (swampy in the past) [10,11]. In the Mediterranean zone the banks are covered by thickets of Rubus edged by Arundo, Phragmites, Lythrum, Melilotus (Figures 1c and 2c), and Mentha (Figure 2a) along the water edge and Persicaria inside the water (Figure 3e). The northern Hula Valley and the Upper Galilee also feature relicts of the historical riparian forests, comprising Salix, Tamarix, Platanus, Fraxinus, and Populus. Toward the south the vegetation becomes more hallophylic, mainly comprising thickets of Tamarix, Pluchea, Arundo, Phragmites, Atriplex, and Juncus, characteristic also for the shores of the Dead Sea (Figure 1a,b). The aquatic flora of Israel is rich and variable, although many water plants have a very restricted distribution [12-14].

The inland water bodies in Israel can be classified as following: rivers, streams, lakes, springs, swamps, and vernal pools.

The largest river in Israel is the River Jordan (=Nehar haYarden), flowing from Mount Hermon through the bottom of the Rift Valley into the Dead Sea (Figure 1f). There are other smaller rivers, streams or brooks ("Nahal" in Hebrew), which flow either into the Mediterranean Sea or the Jordan Valley, most of them seasonal, containing water between once every few years to 1-2 months in winter, while the rest contain water throughout the year or at least for most of the year. Numerous springs occur throughout Israel, some of them used for agriculture or as tourist sites (Figure 3f). These natural springs are surrounded by thick vegetation.

A chain of three lakes formed at the bottom of a tectonic depression stretches along the Jordan Valley: the freshwater Hula Lake, the Sea of Galilee (=Yam Kinneret), and the extremely saline Dead Sea (=Yam haMelah). The shallow Hula Lake $\left(14 \mathrm{~km}^{2}\right)$ surrounded by the Hula swamp $\left(30-60 \mathrm{~km}^{2}\right.$, depending on the precipitation in any particular year) was once exceptionally rich in flora and fauna, until it was drained in the 1950s in order to eradicate malaria and to release land for agriculture. The drainage dessicated the lake and its surroundings, resulting in the loss of most of its biota, with some of the animal and plant species completely disappearing and populations of the remaining species strongly reduced [10,15-17]. Currently, $3.2 \mathrm{~km}^{2}$ comprise the Hula Nature Reserve (Figure 3a-d) with its remnants of the natural vegetation, while $8-10 \mathrm{~km}^{2}$ belong to the artificially flooded Agmon haHula, where attempts are being made to reintroduce the natural biota [18-20]. The Sea of Galilee $\left(170 \mathrm{~km}^{2}\right)$ is the largest freshwater body in Israel. Its shores suffer strongly from human activities (urbanization, agriculture, tourism) and from a lowering of the water level as a result of dessication. The natural vegetation has remained relatively untouched in only a few preserved areas along its east-northern edge. Most of its coast is now either cultivated or features monocultural stands of Arundo, Phragmites, or Tamarix. The Dead Sea $\left(605 \mathrm{~km}^{2}\right)$ features extremely halobiontic conditions. The salinity of its water reaches $35 \%$, and no multicellular organisms can survive in it, although soldier fly larvae (Diptera: Stratiomyidae) have been reported, probably having drifted in with the freshwater flow [21]. Its shores too are strongly saline. In recent years the water level in the Dead Sea has been receeding, and the shores are drying out and crumbling, which strongly affects the coastal flora and fauna. 

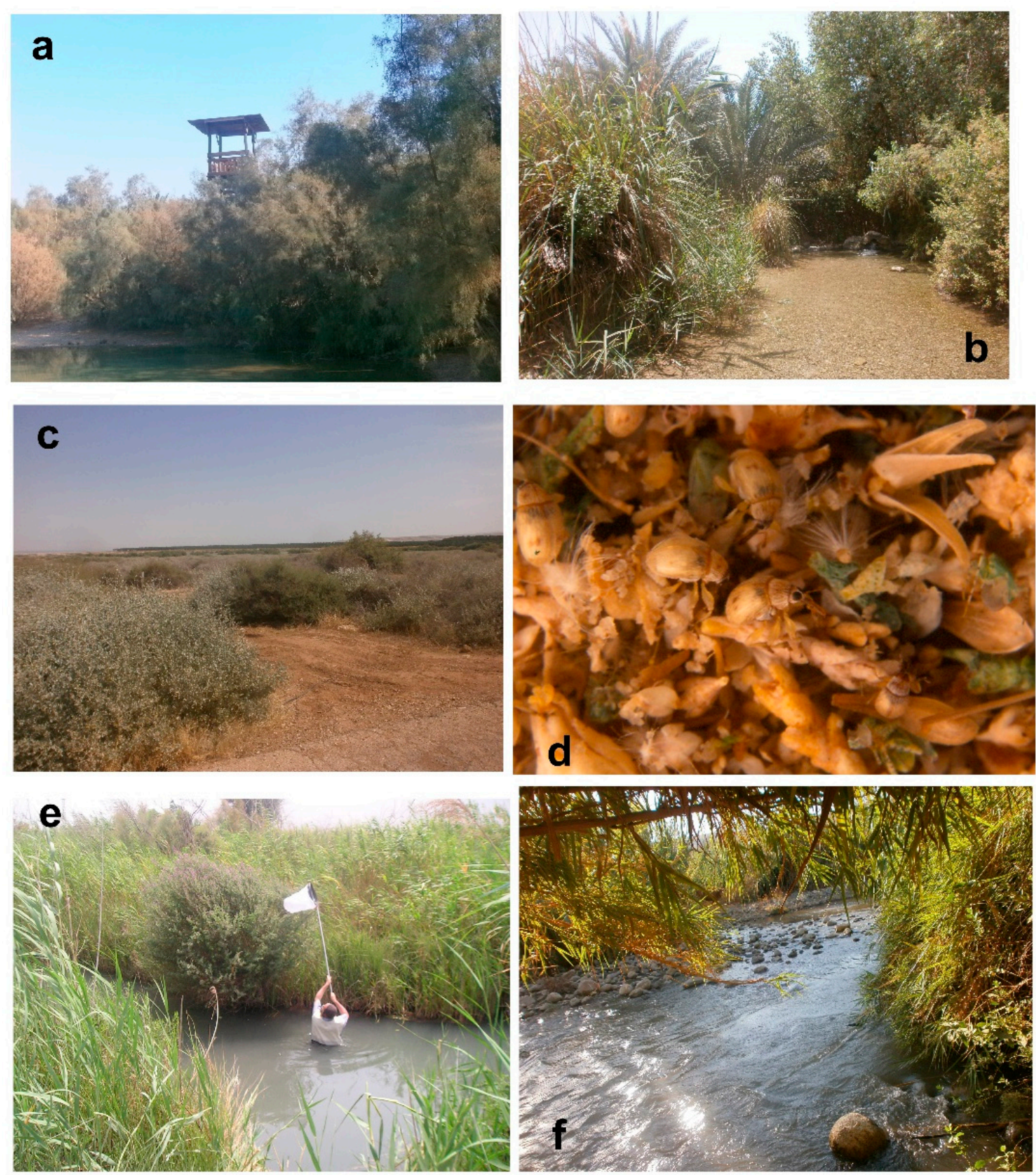

Figure 1. (a) Enot Zuqim Nature Reserve, oasis on the NW coast of the Dead Sea, thicket of Tamarix spp.; (b) same place, Arundo donax, Juncus sp., Phoenix dactylifera, Pluchea dioscoridis, Populus euphratica, Tamarix spp.; (c) Wadi Malha Wetland Nature Reserve, saltmarsh, Jordan Valley, in the foreground Atriplex halimus and Suaeda aegyptiaca, on the background Tamarix sp.; (d) Corimaliini in Tamarix litter (courtesy Amikam Shoob); (e) Nahal Qibbuzim, Bet She'an Valley, the author is sweeping Nanophyini from Lythrum salicaria (photograph taken by one of the author's children); (f) Park haYarden, bank of the Jordan River. 

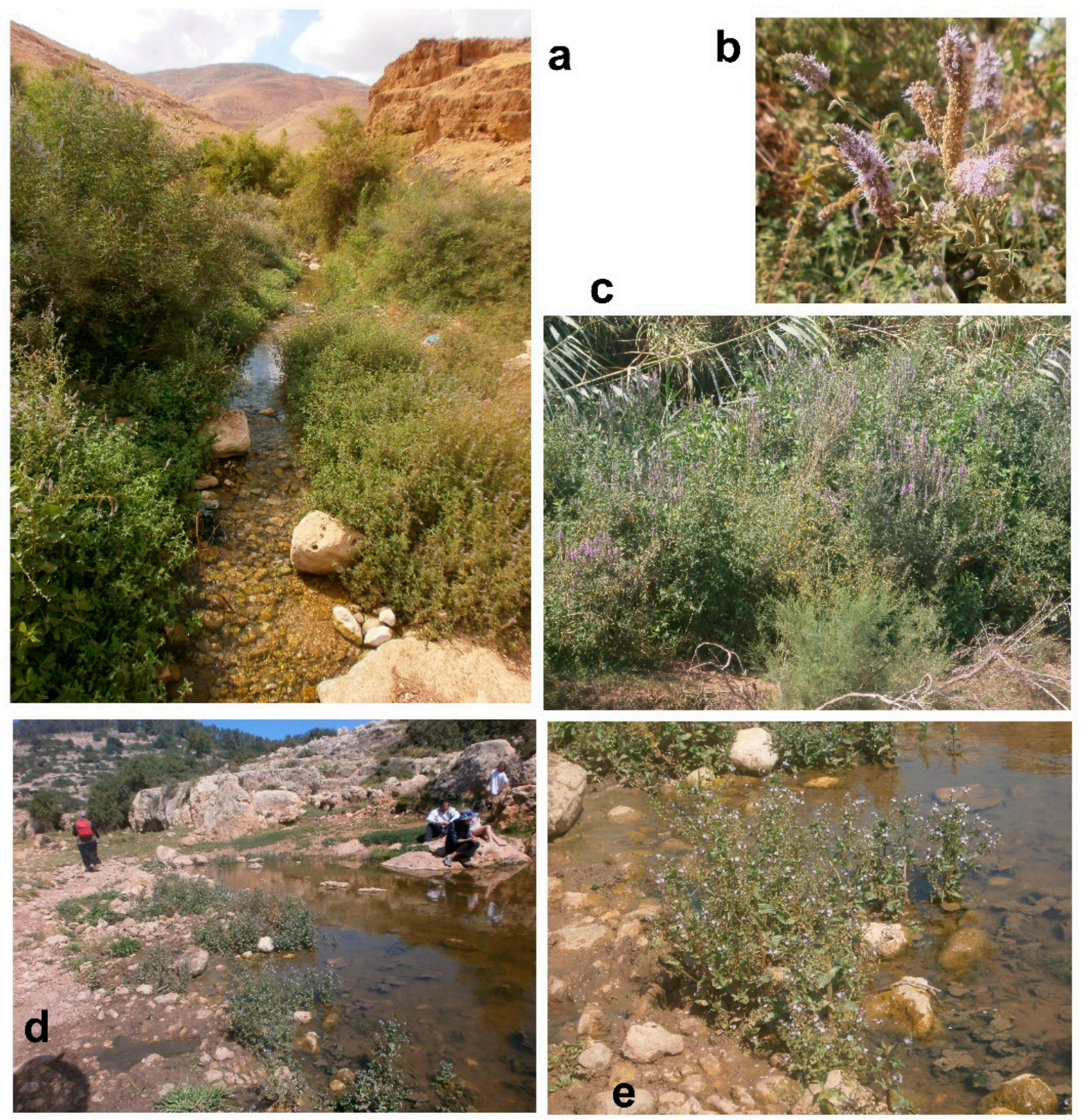

Figure 2. (a) 'En Peza'el, Nahal Peza'el, Jordan Valley, Mentha longifolia, Vitex agnus-castus, Ziziphus spina-christi; (b) same place, blooming Mentha longifolia; (c) Arik Bridge, bank of the Jordan River, Lythrum salicaria, Melilotus albus, Phragmites australis and Tamarix sp.; (d) Nahal Qana, Turtles Pond, Samarian Hills, Veronica anagallis-aquatica growing along the water; (e) same place, Veronica anagallis-aquatica.

Swamps once constituted the most common biotope in the lower areas of Israel, like the coastal plain, Yizre'el Valley and Hula Valley, at least since the Holocene. A nearly continuous chain of swamps once stretched along the Mediterranean coast, dammed in the west by the strip of dunes. These swamps were drained at the end of the 19th and beginning of the 20th century in order to release land for human use and eradicate malaria. Most of them have disappeared completely, while some have become vernal ponds (e.g., 'En Gonen, Ahu Binyamina, Dora, Netanya Pool, Ga'ash Pool (Figure 4f,g)), Basa of Herzliyya, Levinski Pool, Robert's Pool (4h) or were strongly reduced (e.g., Berekhat Ya'ar (Figure 4a), 'En Nimfit (Figure 4c), 'En Afeq, Hula (Figure 3a-d)) and remained only as nature reserves (the latter two are also under the protection of the RAMSAR convention [22]. 

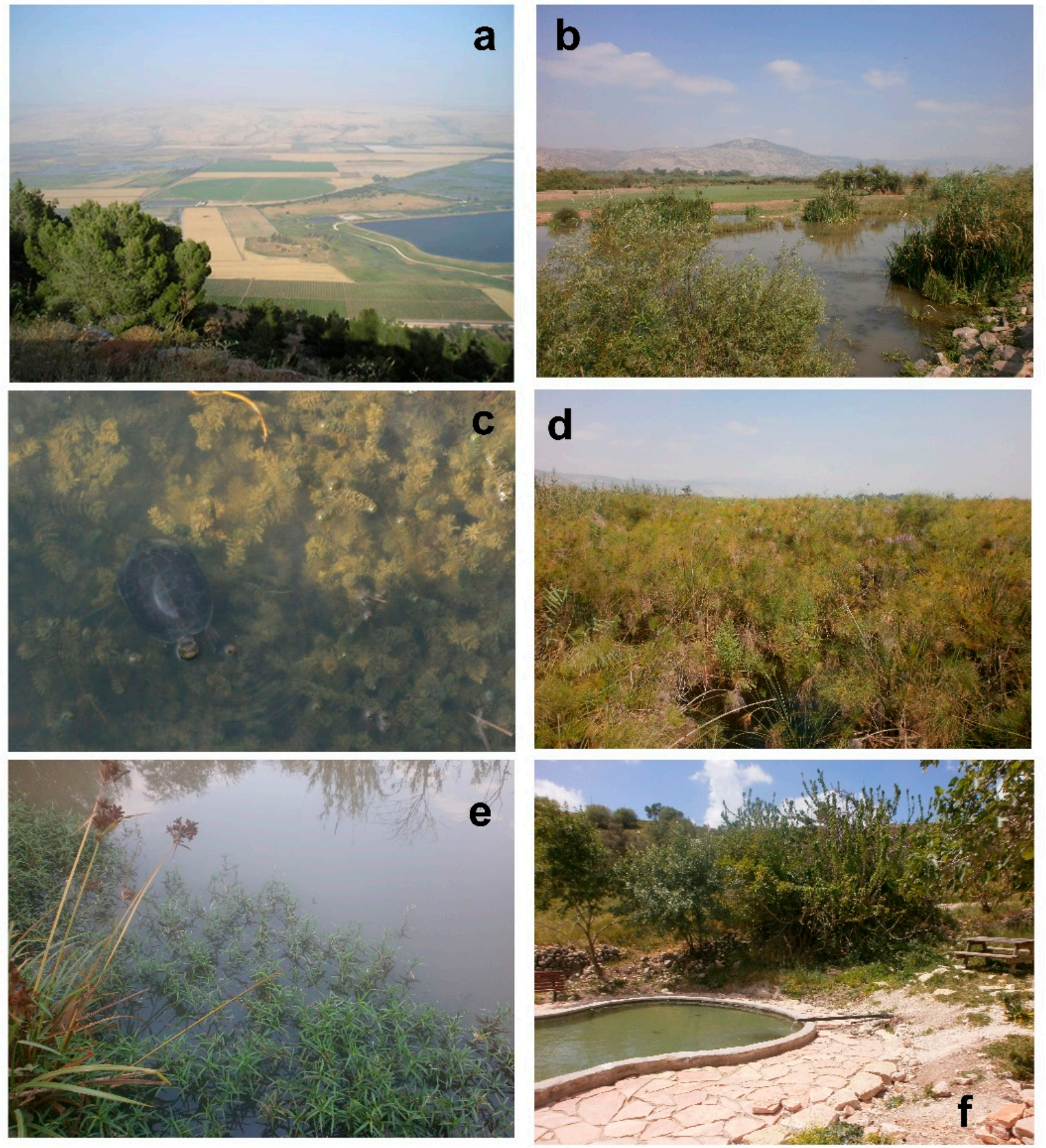

Figure 3. (a) Hula Valley, cultivated part, seen from Naftali Hills, E Upper Galilee; (b) Hula Nature Reserve; (c) Hula NR, Ceratophyllum demersum; (d) Hula NR, Cyperus papyrus, Lythrum salicaria; (e) Park haYarden, bank of the Jordan River, Persicaria decipiens, Cyperus sp.; (f) 'En 'Amassa spring at the foot of Mt. Gerizim, Samarian Hills, cultivated. 

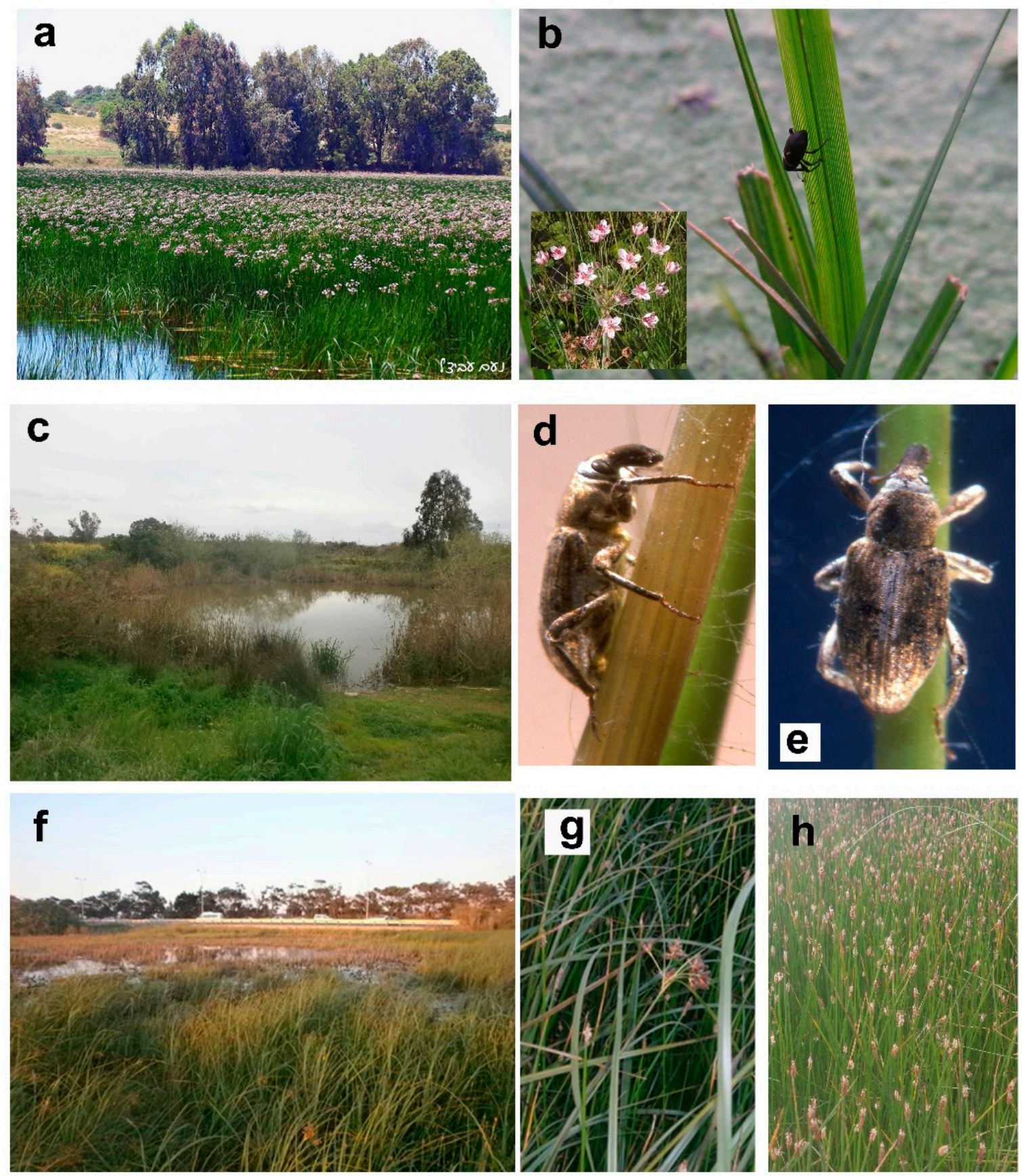

Figure 4. (a) Berekhat Ya'ar, Central Coastal Plain, Butomus umbellatus blooming (courtesy Noam Avitzel); (b) same place, Bagous validus feeding on Butomus umbellatus (courtesy David Furth), on smaller photograph flowers of B. umbellatus; (c) 'En Nimfit Nature Reserve, Migdalit haNehalim Pond, vernal pond; (d) Picia syriaca, lateral view, photographs taken in lab, Tel Aviv University (courtesy Amikam Shoob); (e) same, dorsal view (courtesy Amikam Shoob); (f) Ga'ash Winter Pool Nature Reserve, vernal pool, Eleocharis palustris and Scirpus maritimus; (g) same place, Scirpus maritimus; (h) Nizzanim Dunes Nature Reserve Roberts' Pool, vernal pool, Eleocharis palustris.

Vernal (seasonal, ephemeral) pools, featuring water only during the winter and early spring, occur in Israel along the coastal plain, on the western slopes of the Samarian and Judean Hills, in the uplands of the Upper and Lower Galilee, and on the Golan Heights. In the coastal area they have mainly replaced the historical swamps. Some of the vernal pools may contain water throughout the 
winter, while others are full for only 1-3 months a year or can remain dry for several years. The unique ecosystem of vernal pools enables specialized plants to thrive, some of which can survive or produce dormant life-stages during the dry season.

All wetland habitats in Israel are particularly vulnerable and are under constant threat of physical disappearance, destruction or pollution, particularly because of their fragility and small size. Even innocent and natural human activities such as tourism or cattle grazing can cause serious damage to the riparian and aquatic vegetation, leading to the disappearance of the invertebrate fauna. During the 20th century wetlands in Israel were both exploited actively and destroyed accidently, which led to the loss of up to $80 \%$ of these habitats [23-25]. The insect aquatic fauna too was naturally denser and more variable 100 years ago (e.g., $[16,17,19,26])$. Today, we can only study it in its decline.

In Israel, the taxonomic knowledge on aquatic insects as a whole is limited. However, some groups, such as Ephemeroptera, Odonata, Trichoptera, Diptera (e.g., [16,27-31]), and some of the aquatic beetles [26,32-35] have been studied and published. The aquatic weevil fauna in Israel nonetheless has remained completely unknown. The first records of water weevils in Israel were descriptions of Picia syriaca (Reitter) and Echinocnemus sahlbergi Shilsky. Since then an unidentified species of Bagous was recorded from the Hula Valley [18]. Caldara and O'Brien [36] recorded five species of Bagous in their revision of the Palaearctic Bagous, based on the material deposited in European and American museums. Alonso-Zarazaga and Lyal [37] recorded Aorus anthracinus Branczik; and Friedman [4] recorded Arthrostenus fullo Boheman and Icaris sparganii (Gyllenhal). Comprehensive data on the distribution and biology (where available) of the hygrophilic species of Israel are presented here for the first time.

\section{Materials and Methods}

The majority of the studied material is deposited in the National Collection of Insects, the Steinhardt Museum of Natural History, National Research Center, Tel Aviv University, Israel (SMNHTAU); therefore, this abbreviation is omitted from the Material Examined section. For the specimens from the other museums the following abbreviations are used:

BMNH—Natural History Museum, London, UK (M. Barclay).

HNHM-Hungarian Natural History Museum, Budapest, Hungary.

USNM-National Museum of Natural History, Smithsonian Institution, Washington, DC, USA (L. Chamorro).

ZSMU—Zoologische Staatssamlung München, Munich, Germany (M. Balke).

Drawings and measurements were made using a drawing tube and a stereomicroscope Leica M125, Leica Microsystems GmbH, Wetzlar, Germany. Drawings were scanned and processed using Adobe Illustrator 9.0, Adobe Systems Incorporated, San Jose, CA, USA. Total body length in dorsal view was measured along a straight line from the base of the rostrum to the tip of the elytra. Images of the weevil habitus were captured with a Leica DfC295 digital camera, Leica Microsystems GmbH, Wetzlar, Germany, mounted on a Leica M205c microscope, Leica Microsystems GmbH, Wetzlar, Germany, stacking images with Leica Application Suite 4.2.0, Leica Microsystems GmbH, Wetzlar, Germany, and Helicon Focus 5.3, Helicon Soft Ltd., Kharkiv, Ukraine, and editing the final images when necessary with Adobe Photoshop CS4 Extended, Adobe Systems Incorporated, San Jose, CA, USA. Genitalia were extracted by soaking dry specimens in hot water, removing the posterior abdominal sternites, and boiling them in a 10\% water solution of potassium hydroxide. Extracted genitalia were preserved in glycerin in polyethylene stoppered vials, pinned next to the specimens. Photographs were made by the author, apart from Figures 1d,e and 4a,b,d,e.

Transliterated names of localities in Israel follow the Israel Touring Map and List of Settlements published by the Survey of Israel [8]. Where names of localities have changed, the most recent transliterated Hebrew names are given followed by the old names in brackets: for example-Yeriho [Jericho]. Erroneous spellings are also included in brackets following the correct spelling. Plant 
names and distribution follow Danin and Fragman-Sapir [38]. Regional subdivision of Israel follows Theodor [39], with changes made by Ionescu and Eyer [40].

The hygrophilous weevil species in Israel can be divided into three eco-groups, not always distinct: aquatic, semi-aquatic, and riparian. Aquatic species are considered here to be only those that live on water-growing plants and possess clear adaptations for aquatic life (streamlined body form, rostrum short or bent under the body, body covered by flat attached scales, abdominal segments covered by short dense pubescence, tibia long and slender, with longitudinal row of denticles or/and setae, etc.), and their swimming abilities have been proven either by my own observations or from records in the literature. Aquatic weevils mainly swim in the water rather than on its surface. Semi-aquatic weevils are those that live on the water plants or on the riparian vegetation and seldom enter the water, possessing weak or unclear adaptations to their aquatic surroundings. If they are able to swim, they swim either in the water or on its surface [41]. Riparian species are those that live on the riparian plants, having no adaptations to aquatic life and entering the water only accidentally.

\section{Taxonomy}

\subsection{List of the Hygrophilous Weevils of Israel}

\section{BRENTIDAE}

Apioninae

Kalcapiina

Squamapion delagrangei (Desbrochers des Loges, 1895)

Nanophyinae

Corimaliini

Allomalia quadrivirgata (Costa, 1863)

Allomalia setulosa (Tournier, 1868)

Corimalia schatzmayri Giordani-Soika, 1937

Corimalia torretrassoi Giordani-Soika, 1937

Corimalia latifrons (Pic, 1897)

Hypophyes sp.

Nanophyini Gistel, 1848

Dieckmanniellus cheorieri (Boheman, 1845)

Dieckmanniellus nitidulus (Gyllenhal, 1838)

Nanomimus sp.

Nanophyes sp. 1

Nanophyes sp. 2

Nanophyes sp. 3

\section{CURCULIONIDAE}

Bagoinae

Bagous (Bagous) bagdatensis Pic, 1904

*Bagous (Macropelmus) argillaceus Gyllenhal, 1836

*Bagous (Macropelmus) biimpressus Fåhraeus, 1845

Bagous (Macropelmus) lyali Caldara \& O'Brien, 1998

Bagous (Macropelmus) mingrelicus Tournier, 1874

Bagous (Macropelmus) septemcostatus Chevrolat, 1860

Bagous (Macropelmus) subruber Reitter, 1890

*Bagous (Macropelmus) tempestivus (Herbst, 1795)

*Bagous (Macropelmus) validus Rosenhauer, 1897

*Bagous (Parabagous) libanicus Schilsky, 1911

Brachycerinae 
Erirhinini

${ }^{*}$ Echinocnemus reitteri Schilsky, 1907

Echinocnemus sahlbergi Schilsky, 1911

Echinocnemus gerofiticus Grachev, 2008

Echinocnemus qetura Grachev, 2008

Icaris sparganii (Gyllenhal, 1835)

Picia syriaca (Reitter, 1889)

Tanysphyrini

Arthrostenus fullo Boheman, 1836

Stenopelmus rufinasus Gyllenhal, 1835

Curculioninae

Mecinini

Gymnetron niloticum Kirsch, 1881

Gymnetron tibiellum Desbrochers des Loges, 1900

Tychiini

Tychius bicolor C. N. F. Brisout de Barneville, 1863

Tychius meliloti Stephens, 1831

Conoderinae

Ceutorhynchitae

Phytobiini

*Rhinoncus pericarpius (Linnaeus, 1758)

*Rhinoncus perpendicularis (Reich, 1797)

Entiminae

Sitonini

Sitona lividipes Fåhraeus, 1840

Tanymecini

Tanymecus (Geomecus) musculus Fåhraeus, 1840

Lixinae

${ }^{*}$ Lixus (Eulixus) iridis Olivier, 1807

Molytinae:

Aorus anthracinus Brancsik, 1898

* indicates a new record for the Israeli fauna.

\subsection{Identification Keys to the Hygrophilous Weevils in Israel}

Key to of the weevil taxa in Israel found on, in, or close to water (species of Bagous are keyed separately)

1. Trochanter oblong, at least twice as long as wide, base of femur not touching coxa Brentidae 2

- Trochanter short, at most as long as wide, base of femur touching

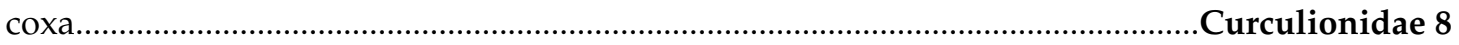

2. Antenna straight, scapus much shorter than funicle, funicle 7-segmented; body oblong, dark; bases of pronotum and elytra not crenulate; pronotum at base usually narrower than elytra (Figures $5 \mathrm{a}$ and $6 \mathrm{a}, \mathrm{b})$; on Mentha longifolia (Figure 2b) Apioninae: Squamapion delagrangei

- Antenna geniculate, scapus longer than or as long as funicle, funicle 4- or 5-segmented; body globular, yellow to light brown; bases of pronotum and elytra crenulate; pronotum at base as wide as elytra (5b-h, 6c-i); on Lythrum salicaria or Tamarix. 
3. Antennal club compact, comprised of fused segments with sutures distinctly visible, obsolete or invisible $(5 \mathrm{~b}-\mathrm{f}, \mathrm{6c}-\mathrm{g})$; male tibia not mucronate; claws free; on Tamarix (Figure 1a-d).

..Corimaliini 4

- Antennal club loose, comprised of distinctly separated segments; male tibia mucronate; claws fused at least at base; on Lythrum (Figures 1e, 2c and 3d). Nanophyini 6

4. Antennal funicle 5-segmented, antennal club with distinct sutures. Corimalia

- Antennal funicle 4-segmented, antennal club with distinct or indistinct sutures. . .5

5. Antennal club with distinct sutures; elytra distinctly crenulate at base; femora with two denticles; if with one denticle only, then denticle distinctly longer than wide; body length 1.5-2.0 $\mathrm{mm}$.

Allomalia

- Antennal club without distinct sutures; elytra not crenulate at base; femora with one denticle or without denticles; body length $0.8-1.5 \mathrm{~mm}$.

Hypophyes

6. 8th elytral interstria completely not crenulate; male pygidium apically with round fovea; femora without denticles or (rarely) with minute denticle.

Nanophyes

- 8th elytral interstria crenulate at least close to base; male pygidium without fovea; femora dentate...

7. 8th elytral interstria crenulate at basal quarter; femora strongly incrassate, with large proximal and small distal denticles.

Dieckmanniellus 8th elytral interstria crenulate between base and humeral callus; femora slightly incrassate, with one minute denticle or (rare) without denticle .Nanomimus

8. Claws dentate; mesothoracic epimeron visible in dorsal view; rostrum as long as pronotum, thick, hidden in rostral channel; body stout, 1.5-4.0 mm (Figure 12a-d)

Rhinoncus 9

- Claws not dentate; mesothoracic epimeron not visible in dorsal view; rostrum and body of various shapes and size, rostral channel present or absent.

9. Claw denticle short, $0.3 \mathrm{X}$ as long as claw, straight, not contiguous to opposite claw denticle at apex; body laterally rounded, black, with slight bluish tinge, body length 2.5-4.0 mm (Figure 12a,c)

Rhinoncus pericarpius

- Claw denticle long, $0.5 \mathrm{X}$ as long as claw, curved, nearly contigous to oposit claw denticle at apex; body laterally subparallel, testaceous to dark brown, body length $1.5-2.0 \mathrm{~mm}$ (Figure 12b,d)...

Rhinoncus perpendicularis

10. Antennal funicle 5-segmented; on Veronica anagallis-aquatica (Figure 2d,e) Gymnetron 11

Antennal funicle 7-segmented . .12

11. Scales on elytral interstriae denser, arranged in three irregular rows (Figure 14e); male rostrum strongly tapering at apex, slightly turned up at apex in lateral view (Figure 14a), female rostrum slightly evenly curved (Figure 14b); body length 1.7-2.0 mm Gymnetron niloticum Scales on elytral interstriae sparser, arranged in one regular row (Figure 14f); male rostrum slightly tapering at apex, slightly evenly bent, not turned up at apex in lateral view (Figure 14c), female rostrum nearly straight (Figure 14d); body length 1.5-1.8 mm

..Gymnetron tibiellum

12. Rostrum as long as wide or shorter, shorter than pronotum. .13

- Rostrum at least $1.5 \mathrm{X}$ as long as wide, as long as or longer than pronotum

13. Rostrum as long as wide; 3rd tarsomere narrow, as wide as 2nd, with lobes separated in distal half only; abdomen segments covered with round scales; body stout, 1.6-2.0 mm long (Figure 10d,e). 
- $\quad$ Rostrum shorter than wide; 3rd tarsomere distinctly wider than 2nd, entirely divided into two rounded lobes; abdomen covered with either piliform scales or combination of round and piliform scales; body oblong, 3.0-7.0 mm long

14. Fore margin of pronotum laterally without postocular tuft of setae; mandibles without mandibular cusp or round scar; body covered by appressed scales only, laterally with wide, pale lateral stripe of white scales (Figure 12g,i).

Sitona lividipes

- Fore margin of pronotum laterally with postocular tuft of setae; mandibles without mandibular cusp or round scar; body covered by appressed, erect and semi-erect scales, unicolorous, laterally without pale lateral stripe of scales (Figure 12h,j)

..Tanymecus musculus

15. Rostrum anteriorly tapering at least from antennal insertion, apically pointed; on Melilotus albus Tychius 16

Rostrum cylindrical, at most slightly widened apically.

.17

16. Metafemur with anteromedian denticle, male protibia without denticle medially; rostrum in lateral view less curved at base and gradually tapering towards apex; upper part of body covered with yellowish scales, scales truncated apically (Figure 14g,i-k)

...Tychius bicolor

- All femora without denticles, male protibia with strong denticle medially; rostrum in lateral view strongly curved at base and strongly tapering from antennal insertion place toward apex; upper part covered with whitish scales, scales pointed apically (Figure 14h,l-n)

Tychius meliloti

17. Elytra apically produced into divergent pointed processes; body oblong, laterally subparallel, $3.8-4.0 \mathrm{X}$ as long as wide (Figure 12f,k)

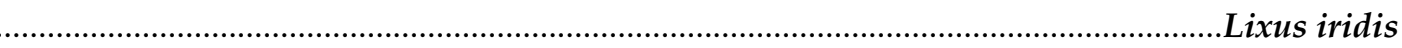

- Elytra apically not produced; body of various shapes, at most 3.3X as long as wide

18. Rostral channel absent; postocular lobes of pronotum absent, at most fore margin of pronotum laterally slightly rounded; antennal sulci covered by scales or bare .

- Rostral channel present; postocular lobes distinct; antennal sulci bare

19. Body black, slender, oblong, smooth and shiny, completely bare (Figure 10g and Figure 11h,i) ........ Aorus anthracinus

- Body of various color, shape and texture, covered densely by scales

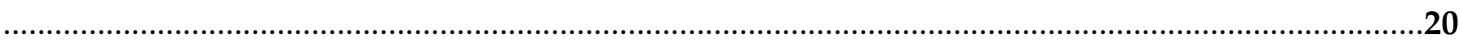

20. 3rd tarsomere cordate; rostrum slender, $4 \mathrm{X}$ as long as wide (Figures $10 \mathrm{~b}$ and 11a) ..Icaris sparagnii

- $\quad 3 r d$ tarsomere narrow, sub-cylindrical, as wide as 2nd at apex; rostrum stout, $2 \mathrm{X}$ as long as wide

21. Tarsomeres 1st-3rd slender, oblong, above $2 \mathrm{X}$ as long as wide, 3rd not bilobed distally; elytra laterally parallel at basal two thirds, strongly acuminate in apical third (Figures 10c and 11b)

Picia syriaca

- $\quad$ Tarsomeres 1st-3rd robust, short, at most $1.3 \mathrm{X}$ as long as wide, 3rd scarcely to distinctly bilobed distally; elytra parallel at basal $4 / 5$, at apical $1 / 5$ weakly acuminate (Figures 10a and 11c)

..Echinocnemus

22. Extant

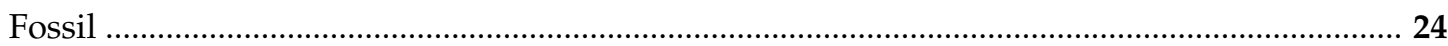


23. Rostrum moderately and evenly curved; tarsi short, 1st tarsomere as long as wide, 2nd-3rd tarsomeres wider than long, 3rd tarsomere distinctly wider than 2nd, bilobed at apex; body length $3.2 \mathrm{~mm}$ (Figures 10a and 11c). Echinocnemus reitteri

- Rostrum straight; tarsi oblong, 1st-3rd tarsomeres longer than wide, equal in length and width; body length $4.5-6.5 \mathrm{~mm}$. ..Echinocnemus sahlbergi

24. Elytron narrower, $5.1 \mathrm{~mm}$ long, uniformly colored. ..Echinocnemus qetura

- $\quad$ Elytron wider, $4.5 \mathrm{~mm}$ long, with wide transverse bands Echinocnemus gerofiticus

25. Head constricted posterior to eyes, eyes prominent, antennal sulci ventral; body covered by oblong apically truncated attached scales (Figures $10 \mathrm{f}$ and 11d-g) Arthrostenus fullo

- Head not constricted posterior to eyes, eyes flat or slightly prominent, antennal sulci lateral; body covered solidly by round scales, usually producing mosaic pattern and sole semierect scales (Figure 7a-Figure 8k).

Bagous

\section{Key to species of Bagous in Israel}

1. Tarsal segments 1-3 transverse or at most as long as wide; 7th segment of flagellum as as wide as 6th, or slightly wider, pubescent in same extent; geophile (collected by sifting or in pitfalls) (Figures $7 \mathrm{k}-\mathrm{m}$ and $8 \mathrm{j}, \mathrm{k}$ ) libanicus

- Tarsal segments 1-3 longer than wide; 7th segment of flagellum distinctly wider than 6th, more densely pubescent; either aquatic or geophiles

2. 1st segment of antennal club bare, smooth, shiny (Figure 8c) biimpressus

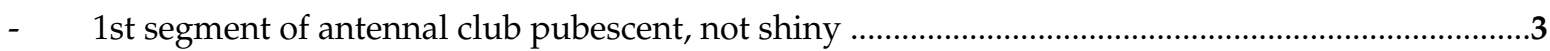

3. Tarsal segments cylindrical or nearly so, as long as wide or slightly longer; 3 rd tarsal segment not or slightly wider than 2nd tarsal segment at apex .

- $\quad$ Tarsal segments trapezoidal, distinctly longer than wide; 3rd tarsal segment cordate or at least distinctly wider than 2nd tarsal segment at apex.

4. Tarsal segments narrowly trapezoidal; body covered with round smooth shiny scales (Figures $7 \mathrm{~b}$ and $8 \mathrm{~b}$ ) argillaceus

- Tarsal segments cylindrical; scales not smooth and shiny.

5. Pronotum granulate; elytral disc flat, no elytral intervals convex; body elongate, slender, legs long, slender (Figures $7 \mathrm{i}$ and $8 \mathrm{~h}$ ); aquatic.

- Pronotum punctate; elytral disc moderately convex, odd-numbered elytral intervals convex; body rounded, stout, legs short, stout; geophilous.

6. Pronotum with small punctures, intervals between punctures distinctly convex, granulose, larger than punctures; elytra subquadrate, $1.30 \mathrm{X}$ as long as wide; tarsomere 2 and 3 subglobose, nearly as wide as long; antennae dark brown (Figures $7 \mathrm{~g}$ and $8 \mathrm{f}$ ). subruber

- Pronotum with large punctures, intervals between punctures more or less convex, narrower than punctures: elytra more rectangular, 1.40-1.55X as long as wide; tarsomere 2 and 3 slightly but distinctly longer than wide; antennae dark reddish (Figures $7 \mathrm{~h}$ and $8 \mathrm{~g}$ ) septemcostatus

7. Pronotum rounded laterally, nearly as wide as elytra; body narrow, $3 \mathrm{X}$ as long as wide; body length $3 \mathrm{~mm}$ (Figures $7 \mathrm{~d}$ and $8 \mathrm{~d}$ ) mingrelicus

- $\quad$ Pronotum subparallel laterally, distinctly narrower than elytra; body oblong, 2.25-2.50X as long as wide

8. 3rd tarsomere narrow, as long and as wide as 1st and 2nd, or only slightly larger, more or less cordate; body length $2.2-4.5 \mathrm{~mm}$ 
9. 3rd tarsomere cordate, lobes separated at least at one third of its length, tarsomeres bare or covered at ventral part by short scales; body length $2.2-2.7 \mathrm{~mm}$ (Figures $7 \mathrm{a}$ and $8 \mathrm{a}$ )

bagdatensis

- 3rd tarsomere subcordate, lobes separated at most at one fifth of its length, tarsomeres covered densely by long thin erect scales, partly piliform and partly wider; body length $3.7-4.5 \mathrm{~mm}$ (Figures 7e,f and 8e) lyali

\subsection{Treatment of Genera and Species}

BRENTIDAE Billberg, 1820 [42]

Apioninae Schoenherr, 1823 [43]

Apioninae are distributed worldwide [44], comprising approximately 700 species in the Palaearctic region [45]. None of the Palaearctic species are known to be aquatic, but some are associated with aquatic or semi-aquatic hostplants and therefore consistently found near the water. Seventy-five species of Apionidae have been recorded so far from Israel, developing on annuals and perennials and inhabiting a wide variety of biotopes, mainly completely terrestrial, all fully-winged and able to fly [46]. Some of them can be found occasionally to frequently in wet habitats, resting on the trees above the water or developing in the annuals along the bank (e.g., Protapion spp., Onychapion poupillieri (Wencker, 1864) [47]), but Squamapion delagrangei is the only species exclusively riparian.

Kalcapiina Alonso-Zarazaga, 1990

Squamapion delagrangei (Desbrochers des Loges, 1895) [48]

(Figure 5a, Figure 6a,b and Figure 13a)

Material examined: 58 exx.

ISRAEL: Har Hermon: Nahal Nimrod, 1082 m, 33ำ $15^{\prime}$ N 35 $45^{\prime}$ E, 18.x.2009, L. Friedman (2 males); Golan Heights: Yehudiyya Forest Nature Reserve [Golan, Qusbiye], 4.v.1979, D. Furth (1 male);

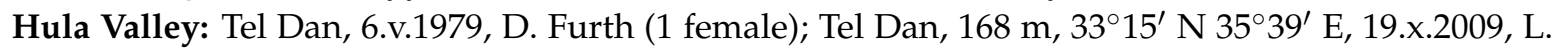
Friedman (2 females) ; Tel Hay, 2 km N, 24.viii.1972, D. Furth (2 males); 'En Gonen Nature Reserve, channel, 19:30-21:00, 18.viii.2014, L. Friedman, on Mentha longifolia (3 males); 'Enot Gonen, 19.viii.2014, L. Friedman, on Mentha longifolia (1 male); 'Enot 'Enan, 18.xi.1973, D. Furth (1 male); Hula Nature Reserve, 12.v.2010, L. Friedman, on Mentha longifolia (16 males, 2 females); Park haYarden, $32^{\circ} 55^{\prime} \mathrm{N}$ $35^{\circ} 38^{\prime}$ E, -200 m, 19.vii.2009, L. Friedman (1 male, 1 female), 24.viii.2014, L. Friedman, on Mentha longifolia (4 males, 1 female); Upper Galilee: Sifsufa, 18.xi.1973, D. Furth (1 female); Lower Galilee: HaSolelim, 3.x.2001, L. Friedman, on Mentha longifolia (11 males, 12 females).

Distribution: Greece, Turkey, Israel [45,46]. In Israel, occuring on Golan Heights, in Hula Valley, Upper Galilee, and Lower Galilee, on banks of streams, ponds, and vernal pools, on its host plant, Mentha longifolia. The latter is widely distributed throughout Israel along various water sources, including extremely arid areas (Samarian and Judean Deserts, Arava Valley), but this weevil was not found south of the Lower Galilee.

Biology: Riparian. On Mentha longifolia L. (Lamiaceae) (Figure 2a,b). Adults active in May-November. 

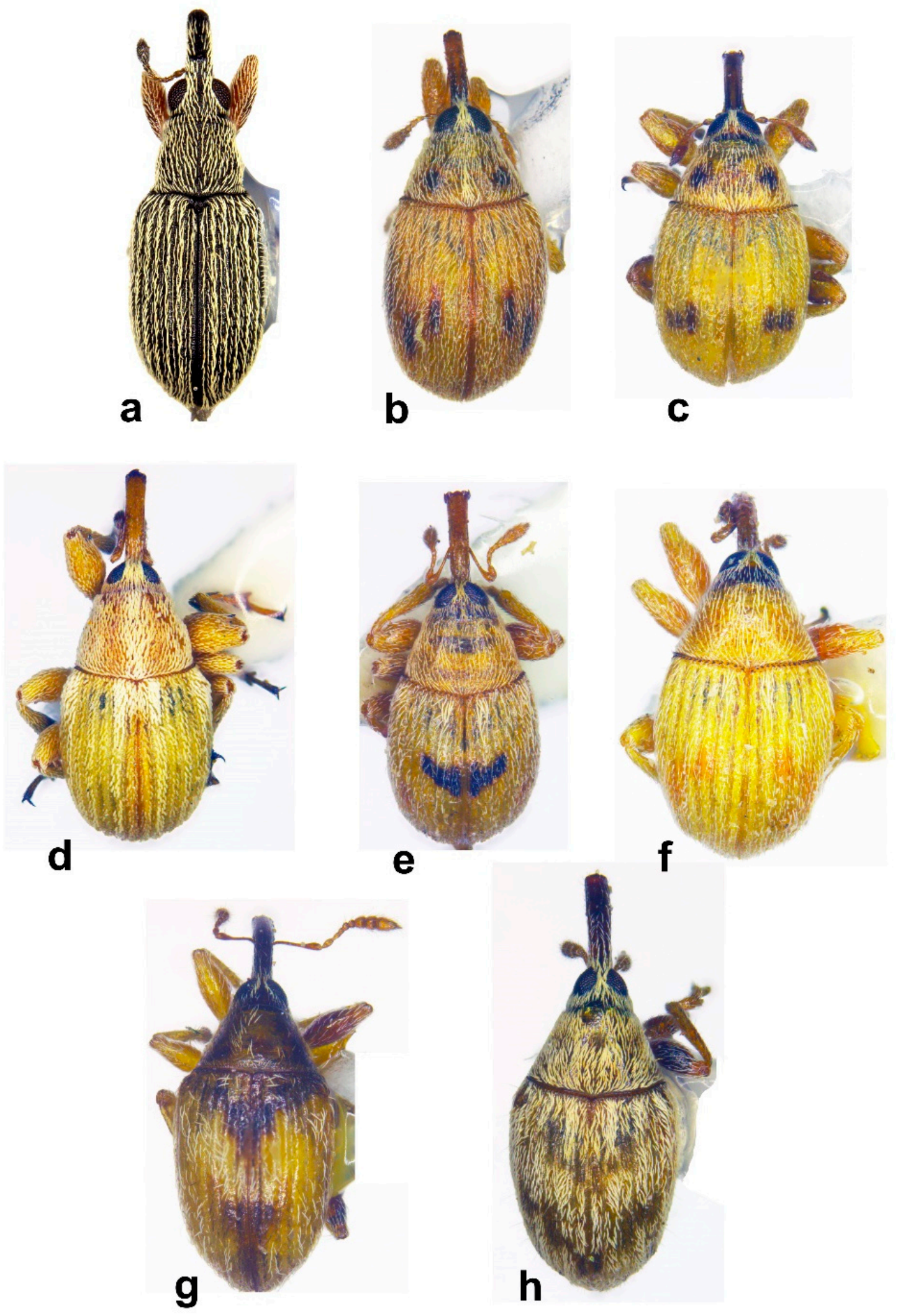

Figure 5. Habitus in dorsal view of (a) Squamapion delagrangei, male; (b) Allomalia quadrivirgata, male; (c) Allomalia setulosa, male; (d) Corimalia latifrons, male; (e) Corimalia schatzmayri, female; (f) Corimalia torretrassoi, male; (g) Nanomimus sp., male; (h) Nanophyes sp. 1, male (not on the same scale). 
Nanophyinae Gistel, 1848 [49]

Nanophyinae are mainly distributed in the Old World Tropics and Eurasia, scarce in the Nearctic region and Australasia, and absent from Central and South America [50,51]. They comprise 107 species in the Palaearctic region [45]. This subfamily has recently been subdivided into two tribes: Corimaliini (47 spp.), associated exclusively with Tamaricaceae (Tamarix, Reamuria) and Nanophyini (60 spp.), associated with various plant families, but mostly with Lythraceae, Ericaceae, Crassulaceae, and Cupressaceae $[50,51]$. There are no aquatic species among Nanophyinae, although there are many riparian ones, living on Tamarix spp. and Lythrum spp. Nanophyinae have well-developed flight wings and fly very well but are unable to swim.

The full data on the Israeli fauna of Nanophyinae await publication because the survey of this group is still incomplete, with some species remaining unidentified and some probably representing undescribed species.

Corimaliini Alonso-Zarazaga, 1989 [50]

(Figures 1a-d, 5b-f and 6c-g)

Corimaliini comprises nine species in three genera in Israel: two species of Allomalia Alonso-Zarazaga, 1989 [50], six species of Corimalia Gozis, 1885 [52], and one species of Hypophyes Reitter, 1916 [53], all associated with Tamarix spp. Six species are riparian. There are approximately 13 species of Tamarix in Israel, some extremely difficult to identify. Some of the Tamarix species prefer saline soil and brackish water and, therefore, grow along the central and lower Jordan River, on the shores of the Sea of Galilee and the Dead Sea and surrounding streams, near springs, streams, and water reservoirs in the Central Negev, and in the swamps and around the natural ponds and artificial fish ponds along the Coastal Plain and the Jordan Valley. Allomalia quadrivirgata (Costa, 1863) [54] (Figures 5b and 6c) and A. setulosa (Tournier, 1868) [55] (Figures 5c and 6d) are the most common Corimaliini species throughout the country, both in the Mediterranean zone and in the desert. They usually occur in large numbers, often with both species occuring together on the same plants. Of six species of Corimalia, C. schatzmayri Giordani-Soika, 1937 [56] (Figures 5e and 6f) and C. torretrassoi Giordani-Soika, 1937 [56] (Figures 5f and 6g) occur along both the northern and central parts of the Mediterranean coast and in the oases along the north-west shore of the Dead Sea (e.g., 'Enot Zuqim Nature Reserve (Figure 1a,b)); C. latifrons (Pic, 1897) [57] (Figures 5d and 6e) occurs in the swamps along the lower Jordan Valley (e.g., Malha Swamp (Figure 1c)) and along the Dead Sea. Hypophyes sp. is rarely found in the Coastal Plain but is common in the Jordan Valley and along the Dead Sea, found frequently both near the water and in completely dry areas.

Biology: Members of Corimaliini in Israel develop in the inflorescence of Tamarix spp. (Tamaricaceae) (Figure 1d). Adults can be found all year round, but are mostly active during the blooming season of Tamarix, when hundreds of specimens, comprising all or some of the aforementioned species, can be observed. Corimaliini are frequently collected in water, but it is clear to me that they have been either swept from the plant or fell down accidently. After falling into the water these small (1-3 mm long) and very light weevils do not sink; they remain above the water and are able to spread their wings and return to the tree. 


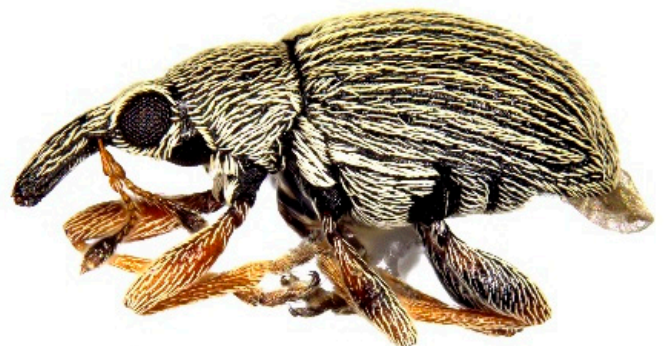

a
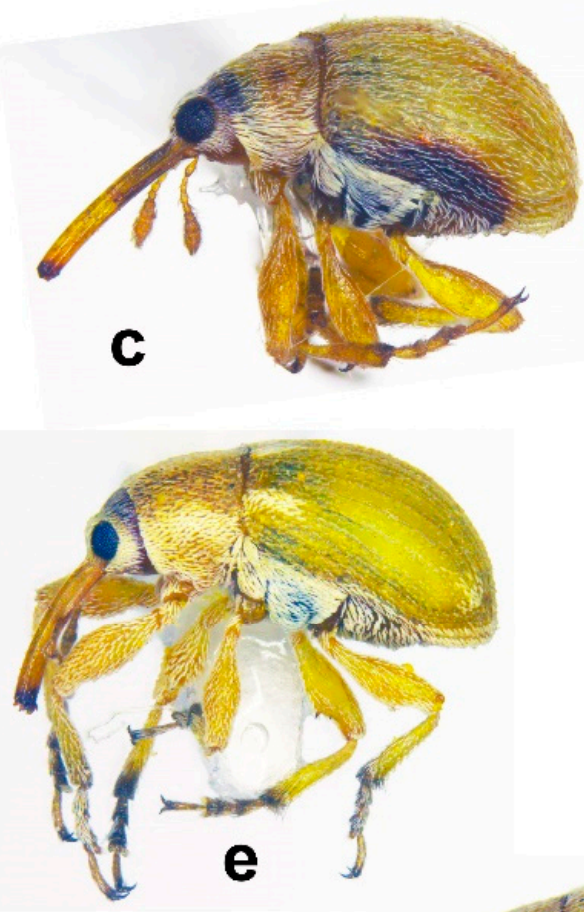
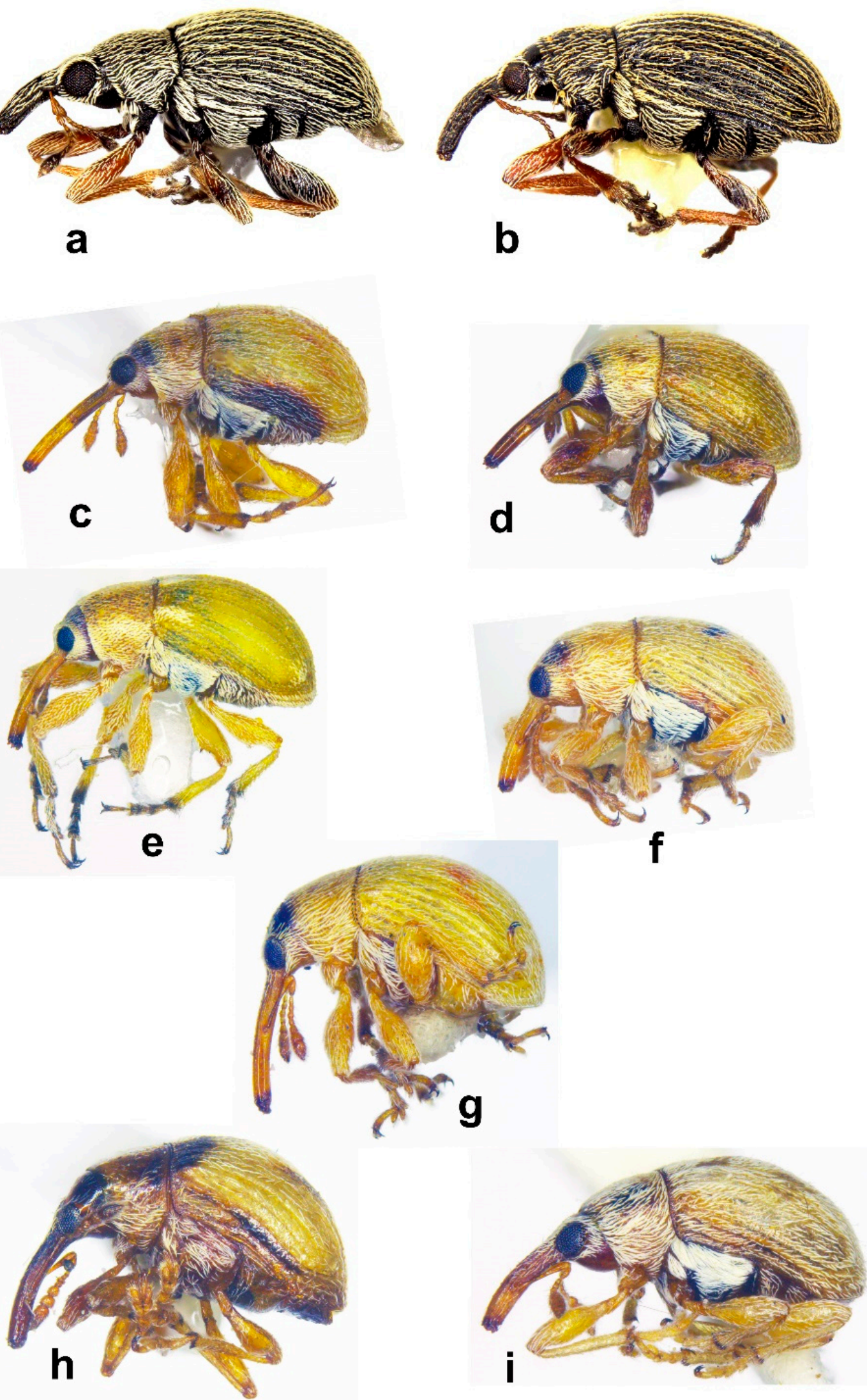

Figure 6. Habitus in lateral view of (a) Squamapion delagrangei, male; (b) Squamapion delagrangei, female; (c) Allomalia quadrivirgata, female; (d) Allomalia setulosa, female; (e) Corimalia latifrons, female; (f) Corimalia schatzmayri, male; (g) Corimalia torretrassoi, female; (h) Nanomimus sp., male; (i) Nanophyes sp. 1, male (not on the same scale). 
Nanophyini Gistel, 1848 [49]

(Figures 1e, 2c, 5g,h and 6h,i)

In Israel, there are seven species in four genera. Six species are riparian: Dieckmanniellus chevrieri (Boheman, 1845) [58], D. nitidulus (Gyllenhal, 1838) [59] (both widely distributed in the Palaearctic region), one species of Nanomimus, and three species of Nanophyes (still not identified). All are associated with Lythrum spp. The distribution of these species corresponds to the distribution of Lythrum, on the banks of streams and ponds and at the edges of swamps, although the majority of species are found in the north of the country. They occur mainly in the Hula Valley, around the Sea of Galilee, on the Golan Heights, in the upper part of the Jordan Valley, and in the Northern Coastal Plain (particularly in the 'Akko Valley), although two species of Nanophyes occur in the northern part of the Central Coastal Plain (Berekhat Ya'ar), and Dieckmanniellus sp. and Nanomimus sp. are found along the Yarqon River and around Tel Aviv. The third species of Nanophyes is known from three specimens collected only on the bank of Nahal haQibbuzim in the Bet She'an Valley (central part of the Jordan Valley) (Figure 1e).

Biology: All the aforementioned species live, feed, and develop on Lythrum (Lythraceae), predominantly Lythrum salicaria L., the most common Lythrum species in Israel (Figures 1e and 2c). Some of the species were collected from several localities in the Hula Valley on Lythrum junceum Banks and Sol. Dieckmanniellus spp. and Nanophyes spp. develop in inflorescences. Nanomimus sp. develops in the stem, but unlike the European species, no stem galls have been found to date. Adults are found in March-September, but mainly in July-August, when the plants are verdant and blooming.

CURCULIONIDAE Latreille, 1802 [60]

The majority of the Recent weevils belong in this cosmopolitan family; which comprises over 51,000 described species [1]. In Israel, it is represented by approximately 800-900 species in 16 subfamilies [4] and unpublished data, 24 of them aquatic, semi-aquatic, or riparian.

Bagoinae C. G. Thomson, 1859 [61]

Bagoini C. G. Thomson, 1859 [61]

A group of unclear status within Curculionidae, but distinct and clearly monophyletic; it comprises about 300 described species (nearly half of them in the Palaearctic region, with no species known from Central or South America) in four closely-related genera [2,62]. The members of Bagoini are predominantly aquatic or nearly aquatic, mainly monophagous (very rarely oligophagous) on aquatic or riparian Angiospermae (Alismatales and Poales), although some are soil-dwellers; some of the species are flightless and some are able to fly; most species are able to swim, possessing morphological adaptations for swimming and breathing in the water [2,36,62,63]. Although Bodenheimer collected a few Bagous specimens, he did not include them in his first list of Israeli weevils [64]; the first time Bagous sp. was mentioned in the literature from Israel was by Dimentman et al. [18]. Five species have been recorded from Israel to date [36,45], and five are recorded here for the first time, all 10 species in the genus Bagous.

Bagous Germar, 1817 [65]

Comprises three subgenera in Israel: Macropelmus Dejean, 1821 [66] with eight species and Bagous (s. str.) and Parabagous Schilsky, 1907 [67] with a single species each [62]. This genus, known to be nearly completely aquatic, is represented in Israel by a composition of five clearly aquatic species, one species (probably extinct) either aquatic or semi-aquatic, three soil-dwellers, and one with unclear habits.

Bagous (Bagous) bagdatensis Pic, 1904 [68]

(Figure 7a, Figure 8a and Figure 9a) 
Material Examined: 6 exx.

ISRAEL: Hula Valley: Hula Nature Reserve, $33^{\circ} 04^{\prime} 11^{\prime \prime} \mathrm{N} 35^{\circ} 36^{\prime} 13^{\prime \prime}$ E, pitfall trap, 8.iv.2010, L. Friedman, C. Drees (2 males, 1 female), 31.vii.2010, L. Friedman, C. Drees (1 female); Hulata, 20.vi.1952, J. Wahrman (1 male); Sea of Galilee Area: Migdal, 27.iii.1932, Y. Palmoni (1 male).

Distribution: South-east Europe (Austria, Hungary, Romania, Italy, Montenegro, Albania, Greece) and south-west Asia (Armenia, Turkey, Israel, Iraq, Iran) [36,45]. In Israel, in the Hula Valley and in the past in the Sea of Galilee Area, in swamps and vernal ponds.

Biology: Probably aquatic. Four specimens from the Hula Nature Reserve in 2010 were collected with pitfall traps placed on the bank of the Hula Lake, which suggests that the weevils spend at least part of their life on the ground. The closely-related European Bagous glabrirostris Herbst, 1795 was recorded from Stratiodes aloides (Hydrocharitaceae) and Ceratophyllum submersum (Ceratophyllaceae). While C. submersum is extremely rare in Israel, its relative Ceratophyllum demersum L. is a common aquatic plant in the Hula Valley (Figure 3c).

Notes: The specimen from Hulata was probably the source of the record in Dimentman et al. [18].

Bagous (Macropelmus) argillaceus Gyllenhal, 1836 [69]

(Figures $7 b, 8 b$ and 9a)

Material Examined: 7 exx.

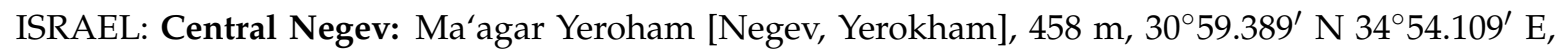
28.ii.2009, Starke (1 male); Ma'agar Yeroham, 24.iv.2014, I. Renan, light trap (4 exx.); Dead Sea Area: 'En Boqeq, 29.vi.2014, I. Renan light trap (2 exx.).

Distribution: West Palaearctic (Europe, Russia, North Africa, Caucasus, Middle and Central Asia) $[36,45]$. First record for Israel. For distribution in Israel see comments below.

Biology: Halobiont [36,70], presumably semi-aquatic. Adults active in February-June. Host plant remains unknown. Dieckmann [70] recorded it on Alisma plantago-aquatica L. (Alismatidae), and Polygonum spp., Rumex spp. (Polygonaceae) in Hungary and Cunev ([71] and pers. comm.) collected a single specimen of Polygonum sp. in Slovakia. The records from Polygonaceae seem occasional. Alisma plantago-aquatica commonly occurs in Israel in the Hula Valley and rarely on the Golan Heights and is completely absent from $B$. argilaceus habitats.

Note: Bagous argillaceus is the only species among the Israeli aquatic weevils that occurs in the desert. This species is distributed widely throughout the Palaearctic region, but is restricted to places with high salinity [26]. In spite of its wide distribution its host plant is unknown. In Israel it was found in two quite different habitats: an artificial freshwater reservoir in the Central Negev (Ma'agar Yeroham = Yeroham Reservoir, at $450 \mathrm{~m}$ a.s.l., with still water; and a spring with brackish water, flowing into the Dead Sea ('En Boqeq), at $-350 \mathrm{~m}$ b.s.l., and resembling it in its high salinity of the banks and aridity of the area. In both places weevils were collected in light traps, in Ma'agar Yeroham one specimen was collected on the vegetation close to the water (Starke, pers. comm.). It can be assumed that B. argillaceus is associated with the same host plant in both localities. The vegetation of 'En Boqeq was thoroughly studied, but no strictly aquatic plants were found. The riparian vegetation comprises Tamarix nilotica (Tamaricaceae), Juncus rigidus (Juncaceae), Arundo donax, Phragmites australis, and Imperata cylindrica (Poaceae), Doellia bovei (Asteraceae) and Adiantum capillus-veneris (Adiantaceae) [72]; the first five also occur in Ma'agar Yeroham. Michael Blecher (pers. com.) suggested that B. argillaceus could have arrived from the nearby Ma'agar Heymar (=Heymar Reservoir, $\sim 5 \mathrm{~km}$ to the south of 'En Boqeq), in which the abiotic factors and aquatic vegetation resemble more those of Ma'agar Yeroham than of 'En Boqeq. 

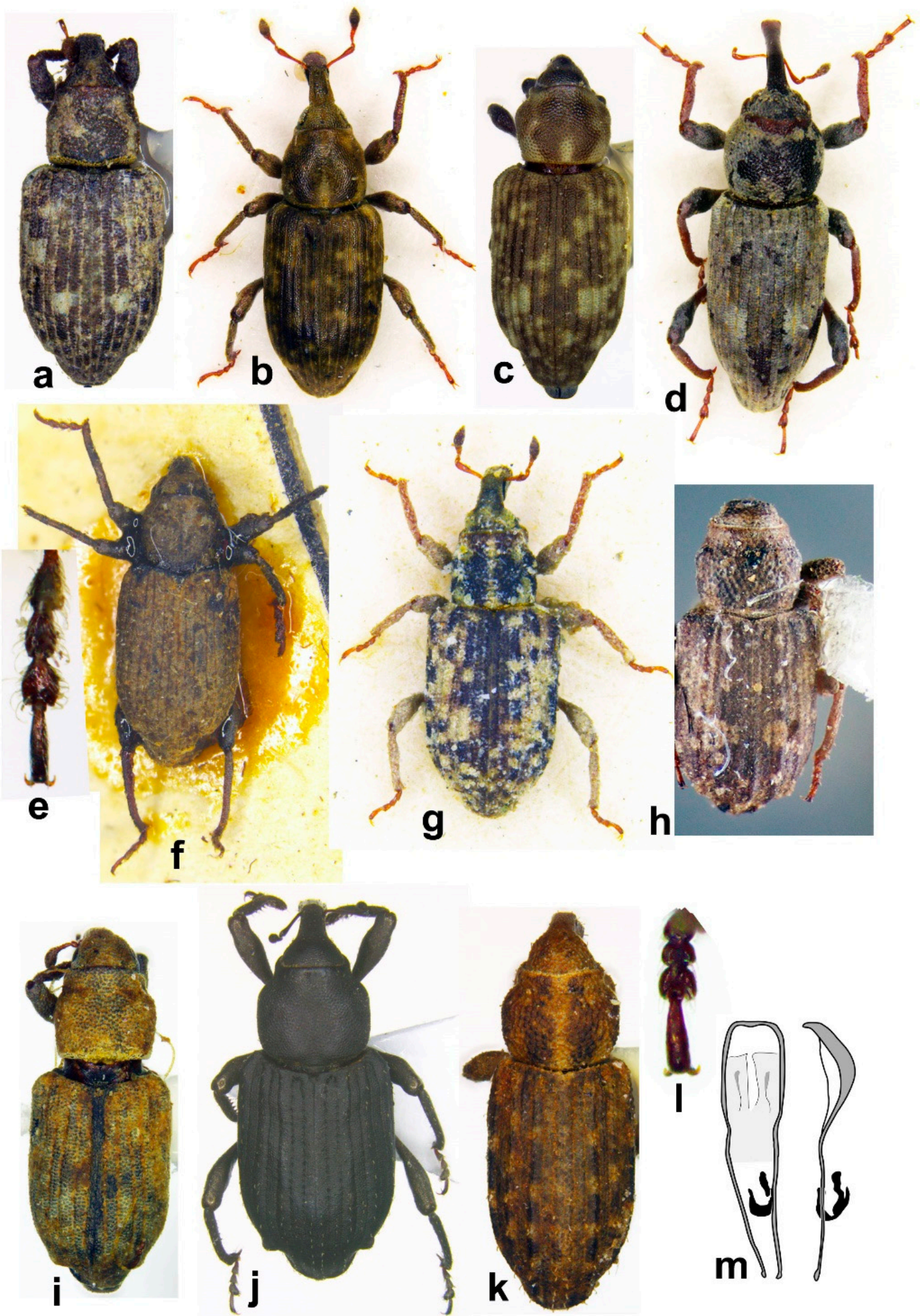

Figure 7. Habitus in dorsal view of (a) Bagous bagdatensis, male; (b) Bagous argillaceus, male; (c) Bagous biimpressus, female; (d) Bagous mingrelicus, female; (e) Bagous lyali, tarsus, male; (f) Bagous lyali, male; (g) Bagous subruber, male (IRAQ: Basra, 1.iv.1936, Frey, ZSMU); (h) Bagous septemcostatus, male; (i) Bagous tempestivus, male; (j) Bagous validus, male; (k) Bagous libanicus, female; (1) B. libanicus, tarsus; (m) B. libanicus, aedeagus (not on the same scale). 

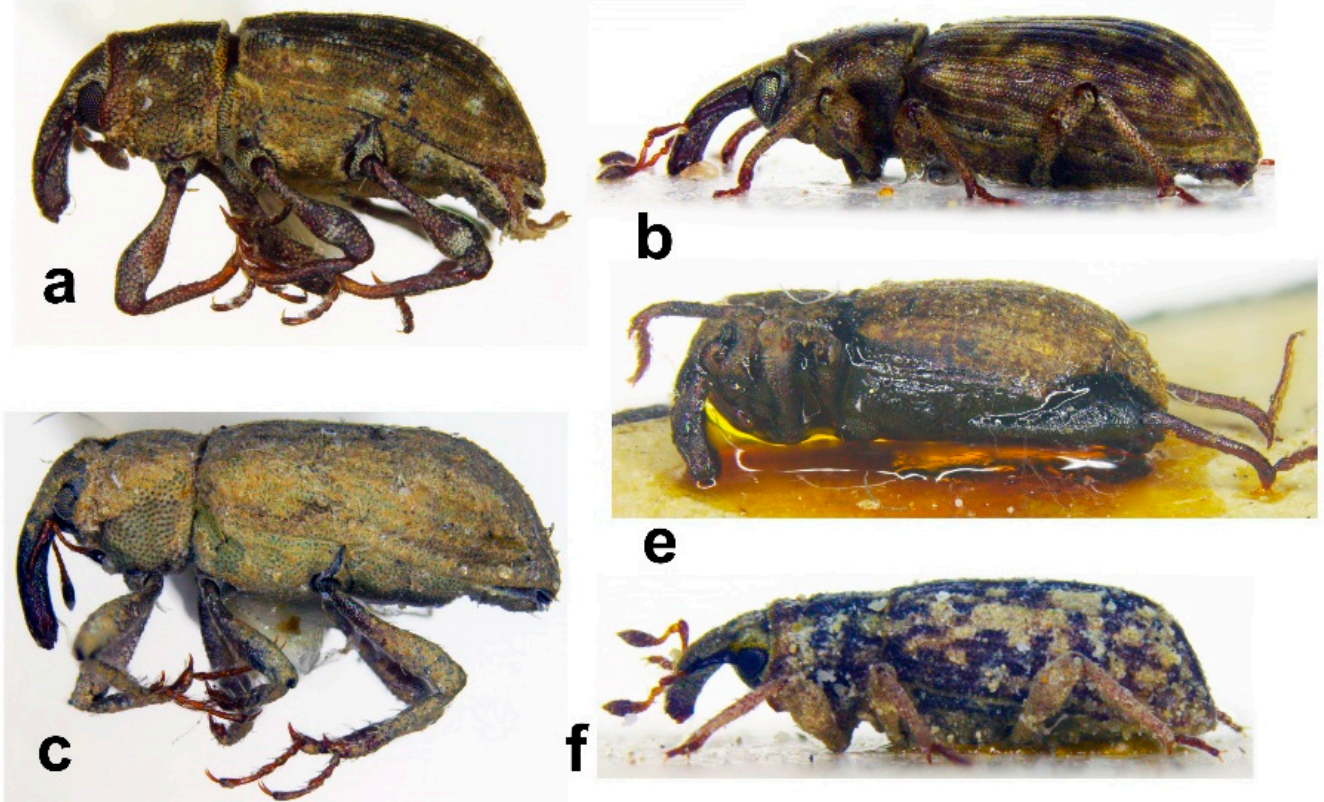

e
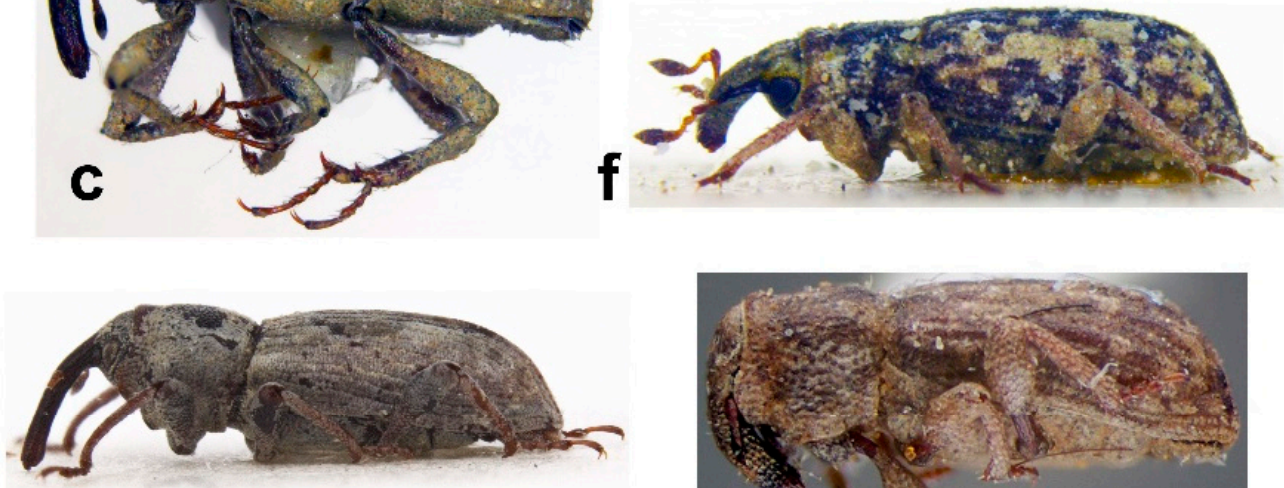

d

g
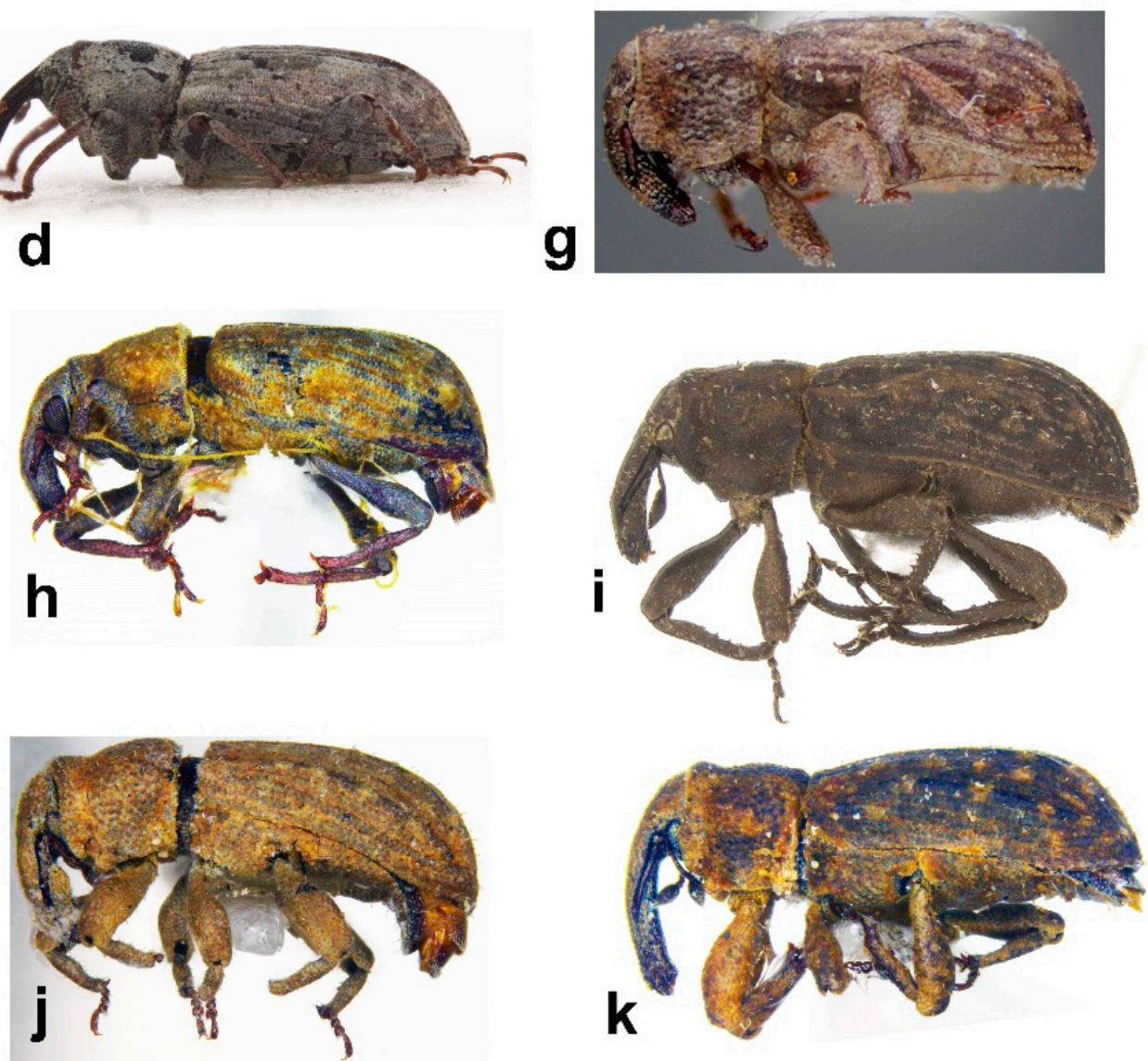

Figure 8. Habitus in lateral view of (a) Bagous bagdatensis, male; (b) Bagous argillaceus, male; (c) Bagous biimpressus, female; (d) Bagous mingrelicus, female; (e) Bagous lyali, male; (f) Bagous subruber, male (IRAQ: Basra, 1.iv.1936, Frey, ZSMU); (g) Bagous septemcostatus, male; (h) Bagous tempestivus, male; (i) Bagous validus, male; (j) Bagous libanicus, male; (k) B. libanicus, female (not on the same scale). 
Bagous (Macropelmus) biimpressus Fåhraeus, 1845 [73]

(Figures 7c, 8c and 9a)

Material Examined: 5 exx.

ISRAEL: Upper Galilee: Dovev Pool, 12.iii.2007, S. Pilosof (1 male); Dovev, 16.iii.2007, S. Pilosof (1 female); Hawwat Matityahu, winter pool [Matytyahu, Hafura], 12.iii.2007, S. Pilosof (1 male); Ramat Dalton, 1.v.2007, S. Pilosof (1 female); Central Coastal Plain: Berekhat Ya'ar, 28.ii.1984, A. Gasith (1 female).

Distribution: Mediterranean region (France, Greece, Italy, Spain, Algeria, Turkey) and Middle Asia (Turkmenistan) [36,45]. First record for Israel. In Israel it is found in winter pools in the Upper Galilee (more recent records) and in the Central Coastal Plain (a single old record).

Biology: Host unknown. Caldara and O'Brien [36] suggested it is halophilic, although in Israel it has been found in non-saline locations. Adults active in February-May. Collected in water-therefore, probably aquatic.

Bagous (Macropelmus) lyali Caldara \& O’Brien, 1998 [36]

(Figures 3d, 7e,f, 8e and 9b)

Material Examined: 10 exx.

ISRAEL: Hula Valley: Hula [Hulah], 5.vii.1934, F. S. Bodenheimer, on papyrus (4 males, 6 females)—topotypes.

Distribution: Described from Israel [36]. Probably an endemic of the Hula Valley.

Biology: Presumably semi-aquatic. It is noted on the labels that the specimens were collected on Cyperus papyrus L. (Cyperaceae) (Figure 3d). It is unclear whether the weevils are associated with this plant, or were just collected in the thicket of papyrus characterizing the Hula swamp. My numerous attempts to re-collect this species on C. papyrus or surrounding vegetation in the Hula failed.

Note: To date the species is known only from the single series, resulting from a single collecting event. Five specimens were sent by F.S. Bodenheimer to the British Museum in London for identification and became types 50 years later, and 10 specimens remained in Bodenheimer's collection, later incorporated in the SMNHTAU collection. B. lyali has not been collected since, despite my numerous recent atttempts. I suspect the species has become extinct after the drainage of the Hula Valley; however, I do not give up hope that it will be rediscovered, as happened with the Hula painted frog Latonia nigriventer [15,74].

Bagous (Macropelmus) mingrelicus Tournier, 1874 [75]

(Figures $7 d, 8 d$ and 9b)

Material Examined: 5 exx.

ISRAEL: Golan Hights: Yehudiyya Forest Nature Reserve [Qusbiye], 28.iv.1974, D. Furth (1 female); Yizre'el Valley: Nahalal, 27.iii.1932, Y. Palmoni (1 female); Central Coastal Plain: Nahal Barqan, 13.iv.1997, R. Hoffman (1 male, 2 females).

Distribution: Greece, south of the European part of Russia, Georgia, Turkey, Israel [36,45]. The collecting records suggest that at least in the past $B$. mingrelicus was widely distributed throughout northern and central Israel, but it has not been collected in the last few decades. Recorded by Caldara and O'Brien [36] from the Southern Coastal Plain (Miqwe Yisrael Agricultural School [Mikve Israel], 1931, F. S. Bodenheimer (2 exx., BMNH)) and Judean Hills (Yerushalayim [Jerusalem], Reitter (1 exx, HNHM)). The record from Yerushalayim by Reitter does not really note the existence of B. mingrelicus in the city (750-800 $\mathrm{m}$ a.s.l., arid surrounding), but probably refers to one of the numerous springs on 
the western slopes of the Judean Hills, most of them recently dry or used for agriculture or cultivated and visited by many tourists, and therefore their flora and fauna strongly degraded.

Biology: Aquatic. No data on host plants are available.

Bagous (Macropelmus) septemcostatus Chevrolat, 1860 [76]

(Figures $7 \mathrm{~h}, 8 \mathrm{~g}$ and $9 \mathrm{c}$ )

Material examined: No material is deposited in SMNHTAU. Caldara and O'Brien [36] recorded it from Israel for one specimen, deposited in USNM, labeled: "Israel, 1-7.iii.1968, S. Bleszynski". I was provided with the photographs of this specimen and its label by Lourdes Chamorro, USNM.

Distribution: Mediterranean (Spain, Morocco, Algeria, Tunisia, Libya, Turkey, Israel) [36,45].

Biology: Geophilic. No data on host plants are available.

Notes: The collecting label of a single specimen of B. septemcostatus lacks the name of the locality, probably because the collector did not have an opportunity to label it himself. The late lepidopterist Stanislaw Bleszynski (1927-1969), a specialist of Crambidae (Lepidoptera), was killed in a road accident in 1969 [77] and Freidberg (pers. comm.). In 1968 he spent nearly an entire year in Israel, studying the Israeli Crambidae fauna, collecting mainly in light traps. Some of the insects that he collected (mainly moths) are deposited in SMNHTAU, most of them have remained unlabeled and kept separately until recently. It was thus clear that at the beginning of March 1968, he was collecting around the southern part of the Sea of Galilee (Kinneret (settlement), 4.iii.1968, Tel Qazir, 5.iii.1968, Teverya, 7.iii.1968). Caldara and O'Brien [36] noted that the mesothoracical wings are fully developed, and the weevil is probably able to fly. Therefore, it is possible that it was collected in a light trap in the southern part of the Sea of Galilee. This is a low (200 m b.s.l.), humid area, which was swampy in the past, and has recently undergone almost complete change due to human activities (roads, agriculture, industry, etc.). The ongoing drying of the Sea of Galilee and lowering of its water level have exterminated most of the natural habitats, particularly in its southern more human-populated part, so that it is unclear whether B. septemcostatus still occurs in this area or where to look for it.

Bagous (Macropelmus) subruber Reitter, 1890 [78]

(Figures $7 \mathrm{~g}, 8 \mathrm{f}$ and $9 \mathrm{c}$ )

Material examined: No material is deposited in SMNHTAU. Caldara and O'Brien [26] recorded it from Israel from 10 specimens from Wadi Ghuzze, collected by N. Scott (the collecting date is not noted) and deposited in BMNH. The photographs show a male specimen from Iraq (IRAQ: Basra, 1.iv.1936, Frey, ZSMU).

Distribution: Mediterranean (Spain, Greece, Algeria, Libya, Tunisia, Egypt, Israel) and south-west Asia (Iraq, Iran, Saudi Arabia) [36,45]. The name Wadi Ghuzze refers to the lower part of Nahal Besor, one of the largest brooks in the southern part of Israel, stretching for approximately $80 \mathrm{~km}$ from the Boqer plateau to the Mediterranean coast. Therefore, the only record from Israel is either from the Southern Coastal Plain or the Northern Negev.

Biology: Geophilic. Collected by sifting in saline soil under Arthrocnemum sp. (Chenopodiaceae) (Meregalli and Borovec, pers. comm.) and under Frankenia pulverulenta L. (Frankeniaceae) (Sprick, pers. comm.) [36]. These plants are absent or vary rare in the lower Nahal Besor (the only collecting locality of B. subruber in Israel), but occur in the swamps and salt marshes around 'Akko in the Northern Coastal Plain.

Bagous (Macropelmus) tempestivus (Herbst 1795) [79]

(Figures 7i, 8h and 9c)

Material examined: 1 ex. 
ISRAEL: Upper Galilee: Ramat Dalton, 21.ii.2007, S. Pilosof (1 male).

Distribution: Europe, Siberia, Russian Far East, Georgia, Turkey [36,45]. In Israel a single specimen was found in a vernal pond. First record from Israel, apparently the southernmost border of its distribution.

Biology: Aquatic. In Europe reared from the stems of Ranunculus repens L. (Ranunculaceae) and collected on Ranunculus spp. and Potamogeton spp. (P. lucens L., P. natans L., P. crispus L.) (Potamogetonaceae) [36]. Twenty-one species of Ranunculus and eight species of Potamogeton occur in Israel; the aquatic Ranunculus constantinopolitanus (DC.) D'Urv., R. peltatus Schrank, R. scandicinus (Boiss.) P.H. Davis, Potamogeton nodosus Poir. and P. pectinatus L. occur in the the Upper Galilee and can be potential hosts.

\section{Bagous (Macropelmus) validus Rosenhauer 1847 [80]}

(Figures 4a,b, 7j, 8i and 9c)

Material Examined: 50 exx.

ISRAEL: Central Coastal Plain: Berekhat Ya'ar, 21.iii.2000, A. Gasith (1 female), 14.v.2003, L. Friedman (5 males, 4 females), 23.v.2003, A. Freidberg ( 8 males, 2 females), L. Friedman (11 males, 6 females), 6.vi.2003, A. Freidberg (1 male), 28.iv.2004, L. Friedman (2 males, 2 females), 23.iii.2009, G. Wizen (1 male, 1 female), $32^{\circ} 24^{\prime} 39^{\prime \prime} \mathrm{N} 34^{\circ} 45^{\prime} 02^{\prime \prime}$ E, pitfall trap, 16.iii.2010, L. Friedman, C. Drees ( 1 female), 17.iii.2010, L. Friedman, C. Drees (1 male, 3 females), 20.vii.2010, L. Friedman, C. Drees (1 female), 15.iii.2018, L. Friedman (1 male, 1 female).

Distribution: Central and Southern Europe, Turkey, Syria [36,45]. First record for Israel. The closest previous record is from central Syria (Homs) [70], more than $300 \mathrm{~km}$ north of the recent locality.

In Israel it is found exclusively in Berekhat Ya'ar (=Forest Pool) (Figure 4a), the seasonal winter pool and swamp south of Hadera, the last remnant of the swamp belt stretching along the coast until the drainage in the 1930s. Most of the specimens were collected by sweeping and beating the water plants, six specimens were collected in pitfall traps placed close to the water, three specimens were observed on 15.iii.2018 in the evening, feeding on leaves of B. umbellatus (Figure 4b).

Biology: Aquatic. Butomus umbellatus L. (Butomaceae) (4a,b); larvae develop in leaves [70]. $B$. umbellatus is a very common water plant in the seasonal and constant water bodies throughout the Central Coastal Plain and in the Golan Heights, but B. validus was found only in Berekhat Ya'ar. Adults active in March-May.

\section{Bagous (Parabagous) libanicus Schilsky, 1911 [81]}

(Figures $7 \mathrm{k}, 1, \mathrm{~m}, 8 \mathrm{j}, \mathrm{k}$ and $9 \mathrm{~b}$ )

Material Examined: 16 exx.

ISRAEL: Upper Galilee: 'En Ya'aqov, 14.i.2007, I. Shtirberg (1 male); Hurfeish, batha, $675 \mathrm{~m}$, $33^{\circ} 01^{\prime} \mathrm{N} 35^{\circ} 21^{\prime}$ E, pitfall, 27.xii.2005, A. Timm, Th. Assmann (1 female), 10.i.2006, A. Timm, Th. Assmann (1 male), 6.ii.2006, A. Timm, Th. Assmann (1 male); Ziv'on, batha, $712 \mathrm{~m}, 33^{\circ} 01^{\prime} \mathrm{N} 35^{\circ} 25^{\prime} \mathrm{E}$, pitfall, 5.iii.2006, A. Timm, Th. Assmann (1 male, 1 female); Har Meron, 5.ii.2007, T. Levanony (1 male); Biriyya, batha, plot 21(1), sifting, 18.iii.2008, T. Levanony (1 female); Lower Galilee: ?Segev, 1985-1986, M. Warburg (1 male); Yizre'el Valle: Merhaviyya, 2.ii.2001, L. Peled (1 female), 9.ii.2004, L. Peled (1 female); Judean Hills: 'Adullam, 3.iv.2003, E. Columbus, T. Levanony (1 female), 15.i.2004, E. Columbus, T. Levanony ( 3 males, 1 female).

Distribution: Described from Lebanon [36]. First record for Israel. In Israel it appears to be widespread throughout the Mediterranean zone from the Lebanese border in the north to at least the south-west slopes of the Judean Hills. 
Biology: Geophilic, lives in soil under leaf litter in the Mediterranean oakwoodland and shrubland (batha). Most of the specimens were collected with pitfall traps or by soil sifting. Hosts unknown. Adults active in January-April.

Notes: This enigmatic species was described from a single female from Lebanon (precise locality unknown), supposedly deposited in the Schilsky Collection in the Museum der Naturkunde für Humboldt Universität zu Berlin, Germany, but was not found there by Caldara and O'Brien [36], who published a translation of its original description from German into English. Its photographs and the schematic drawing of its aedeagus are published here for the first time.
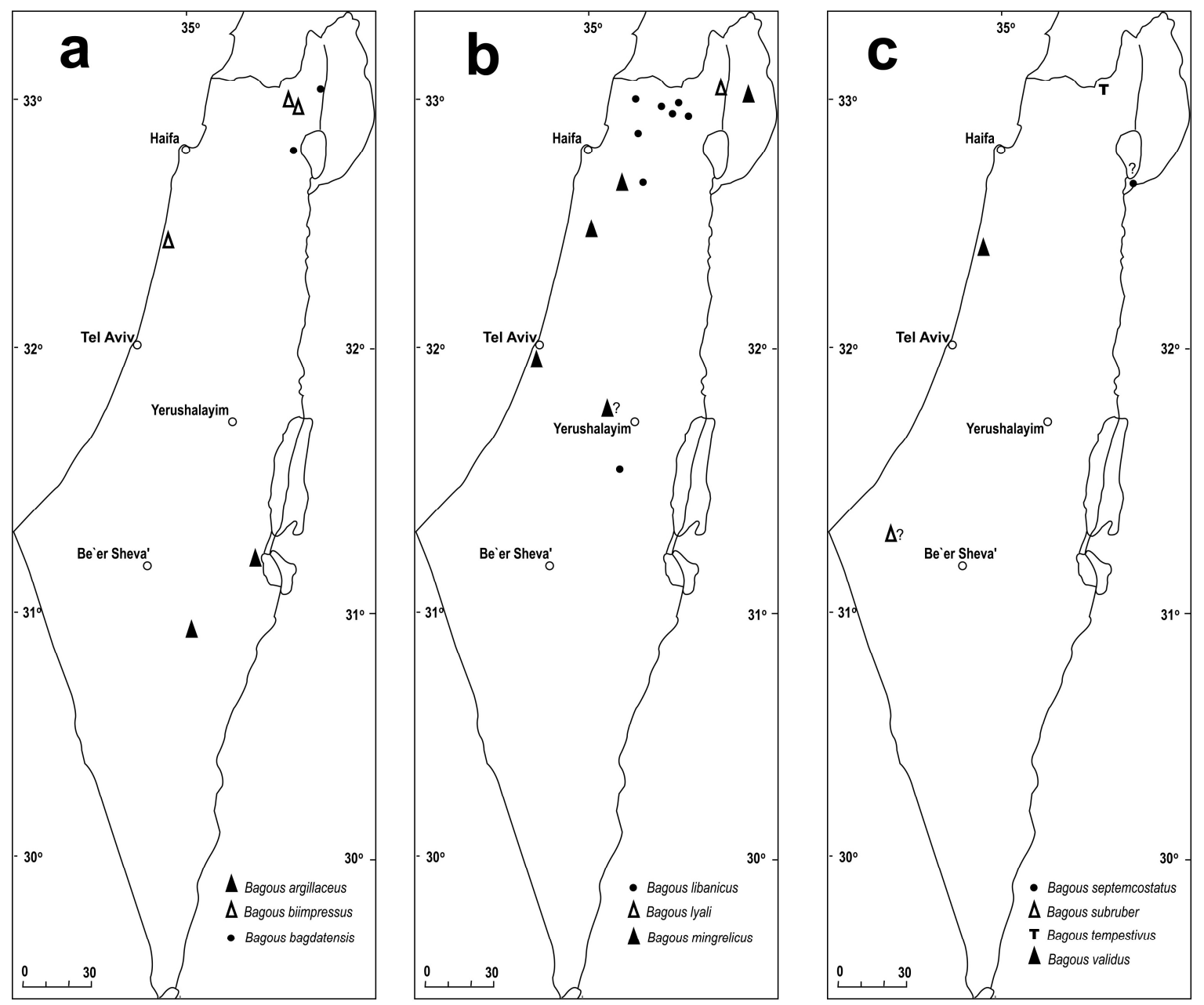

Figure 9. Distributional maps of Bagous (a) B. argillaceus, B. bagdatensis, B. biimpressus; (b) B. libanicus, B. lyali, B. mingrelicus; (c) B. septemcostatus, B. subruber, B. tempestivus, B. validus.

Brachycerinae Billberg, 1820 [42]

Tribe Erirhinini Schoenherr, 1825 [82]

Echinocnemus Schoenherr, 1843 [83]

An aquatic genus with twelve species in the Palaearctic region [45], and above 100 species in Afrotropical, Oriental, and Australasian regions [37,84]. Two extant and two fossil species were recorded from Israel. The fossil species are from the Late Cretaceous (Turonian, 89.8-93.9 Ma) deposits in the southern Arava Valley (in Qetura and Gerofit, respectively): Echinocnemus qetura Grachev, 2008, and E. gerofiticus Grachev, 2008 [85] (Figure 13b), both known only from a single right elytron. In the 
Turonian this area mainly comprised mangroves and coastal marshes on the shore of the ancient Tethys Sea $[86,87]$. The southern part of the Arava Valley is currently an extreme desert with sparce and irregular precipitation and very limited water sources, comprising springs and fast-drying vernal winter pools, making the finding of any aquatic or semi-aquatic species there very unlikely.

The extant species, Echinocnemus reitteri and E. sahlbergi, were only collected in 1904 and have not been collected since. Two additional Echinocnemus species occur in Egypt: E. aegyptiacus Desbrochers des Loges and E. tibialis Tournier [45,88], the latter species recorded from the Mediterranean zone-Kirdasa (near Cairo, lower Nile Valley) [88], an environment quite similar to the Mediterranean coast of Israel, where it coexists together with E. reitteri. I assume that they could occur in Israel, at least in the past.

Based on the data on the recent taxa, one can assume that the biology of the extinct species was quite similar to that of the extant Echinocnemus, feeding and developing on the semi-aquatic Poaceae (e.g., Oryza) in the Palaearctic, Afrotropical, and Oriental regions and on the aquatic fern Marsilea (Marsileaceae) in Australia [7,89-92].

Echinocnemus reitteri Schilsky, 1907 [67]

(Figures 10a, 11c and 13b)

Material examined: 1 ex. No material is deposited in SMNHTAU. ISRAEL: Tel Aviv, Sharona [Sarona], U. Sahlberg (1 female, SZMU, ex collection of K. Daniel).

Distribution: Egypt [45,88]. First record for Israel.

Biology: Aquatic. Host plant unknown. According to Sahlberg [93] was collected at February.

Notes: John Sahlberg and his son Unio collected 19 (!) specimens of what they considered E. sahlbergi on the clay bottom of agricultural water bodies (irrigation canals of rice fields?) close to Wadi el Miserara (=Nahal Ayalon) near Sarona, the German Templer agricultural colony [93]. This area is now in the center of Tel Aviv megapolis, Nahal Ayalon is diverted to a new bottom and enclosed in the artificial channel up to its entrance into the Yarqon River, and its old bottom is occupied by the Ayalon Highway, the major intracity transpostation artery of the Gush Dan (Tel Aviv megapolis), including multi-lane highway and a multi-track railway. The only specimen that I studied clearly belongs to Echinocnemus reitteri according to the original description. I assume that the collected series of Echinocnemus included specimens of two species.

No additional specimens of E. reitteri were collected since. The species is either extinct or extremely rare. Its extinction is clearly as a result of the habitat loss.

Echinocnemus sahlbergi Schilsky, 1911 [81]

(Figure 13b)

Material examined: No material is deposited in SMNHTAU. According to the original description [81], the type series comprised four specimens, two granted to Schilsky by Sahlberg, and two remained with Sahlberg.

Distribution: Described from Israel, probably endemic $[93,94]$. So far known from a single locality, Tel Aviv, Sharona, Nahal Ayalon (see comments to E. reitteri).

Biology: Aquatic. Host plant unknown. According to Sahlberg [93] was collected in February.

Notes: This species was overlooked since its description and was not mentioned in any catalog or publication, apart to Sahlberg [93] for more than 100 years. The validity of this species should be proven either by finding the type specimens or by collecting new material. E. sahlbergi was never re-collected since its description, its habitat (assumabely swamps or vernal ponds in the Central Coastal Plain) is largerly disappeared, therefore I assume that this species is either extinct or extremely rare. 
Icaris Tournier, 1874 [75]

A monospecific genus, that is distributed in the Palaearctic and Afrotropical regions [37,90].

Icaris sparganii (Gyllenhal, 1835) [95]

(Figures 4f,g, 10b, 11a and 13a)

Material Examined: 28 exx.

ISRAEL: Central Coastal Plain: Ga'ash, 24.iv.1974, D. Furth (1 male), 10.iii.1975, A. Freidberg (1 male, 1 female), 9.iii.1978, D. Furth (1 male, 1 female), 3.iv.1978, D. Furth (1 male, 2 females), 21.ii.1980, in water (1 male, 1 female), 11.ii.2001, L. Friedman, on Scirpus maritimus (13 males, 4 females), 7.v.2015, L. Friedman, on Scirpus maritimus (1 male).

Distribution: Icaris sparganii is widely distributed throughout the Palaearctic region, forming three subspecies: I. s. cinereus Miller, 1861 [96] (Turkey, Syria), I. s. pertinax Gyllenhal, 1835 [95] (European Russia, Western Siberia, Middle Asia, NE China) and I. s. sparganii Gyllenhal, 1835 [95] (Central, Southern and East Europe, SE Russia, Ukraine, Iran, Mongolia, Russian Far East, and SW China) $[45,97,98]$. Recorded from Israel by Friedman [4]. According to this distributional map, the Israeli population should belong in I. s. cinereus. The subdivision into subspecies is based on Faust [99], who provides a key to the subspecies (which he considers good species). According to this key the Israeli Icaris falls into the nominative subspecies I. s. sparganii. However, the intraspecific variation, even within the 28 Israeli specimens, and the controversy over the key and the distributional ranges of the subspecies leads me to the conclusion that either the subdivision into subspecies is erroneous or I. sparganii comprise a single widely distributed species with some local variation. Consequently, a revision of the Palaearctic Icaris is urgently needed.

In Israel the distribution of Icaris sparganii is restricted to the Ga'ash winter pool $\left(38.5 \mathrm{~m}^{2}\right)$, a vernal pond north of Tel Aviv, wedged between Kibbutz Ga'ash and the coastal highway (Rt. 2), one of the most overcrowded roads in Israel (Figure 4f). However, the host plant is common along the Northern and Central Coastal Plain, in the Yizre'el and Jordan Valleys and on the Golan Heights.

Biology: Aquatic. In Israel is associated with Scyrpus maritimus L. (Cyperaceae) (Figure 4f,g). Recorded from Europe on Eleocharis spp. (Cyperaceae) [100], Juncus spp. (Juncaceae), Sparganium spp. (Sparganiaceae) [101]. Adults active in February-May.

Picia Tournier, 1895 [102]

A completely aquatic genus. Comprises three species in the Palaearctic region, distributed mainly in its eremic part (East Mediterranean, Middle East, Middle Asia) [45,84]. Picia sinuatocollis Faust feeds and develops on rice Oryza sativa L. (Poaceae), adults feed on the underwater parts of plants and remain for prolonged periods under water, larvae live inside roots and breathe the air from the aeriferous plant structures. After water drainage they feed on the roots externally. Pupation occurs in the soil pupal chamber $[88,89,103]$. P. sinuatocollis causes serious damage to rice and is considered a severe pest of rice in Middle Asia. In Israel, Picia is represented by a single species, originally described from the northern part of Israel. 

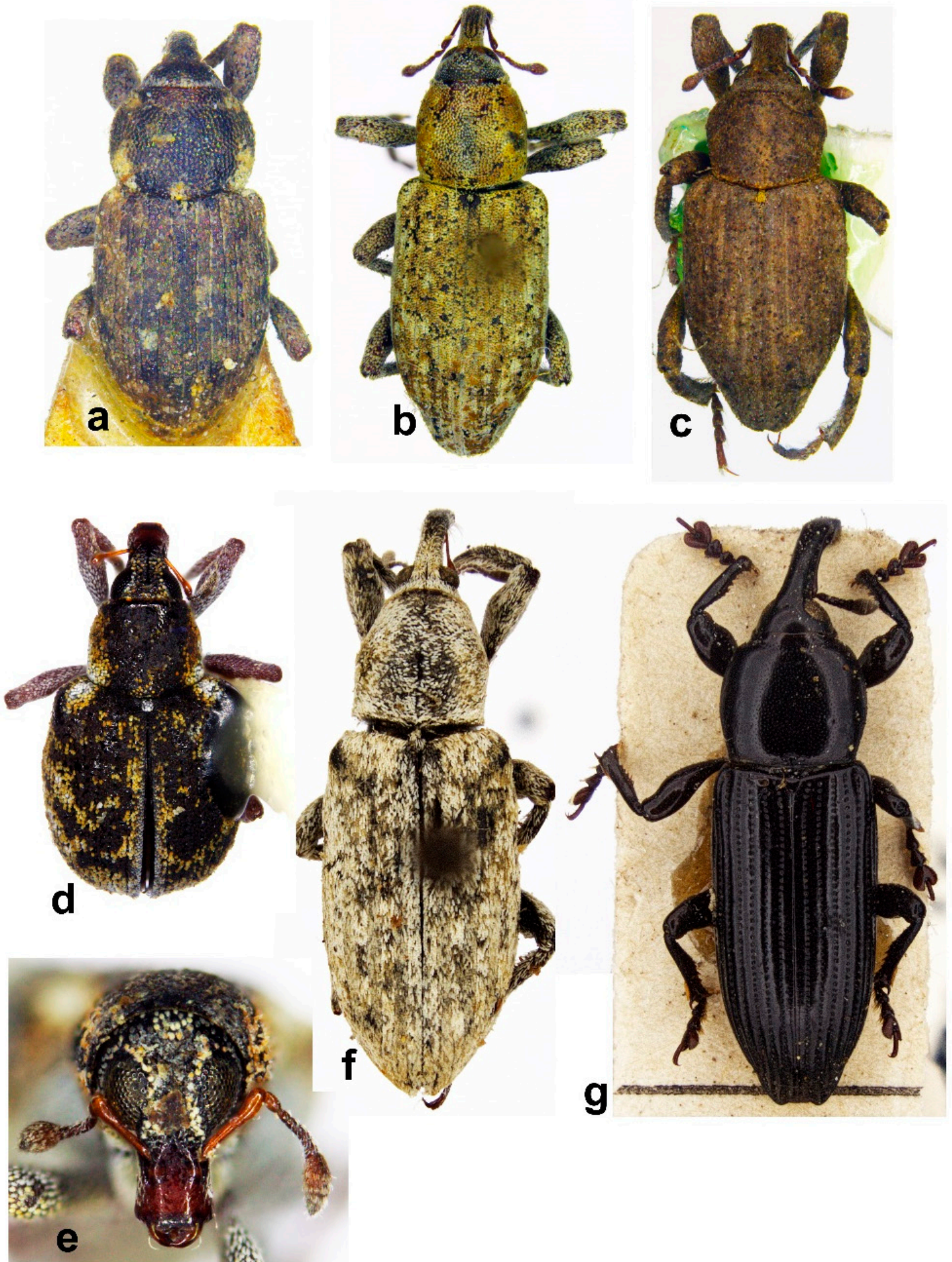

Figure 10. Habitus in dorsal view of (a) Echinocnemus reitteri, female; (b) Icaris sparganii, male; (c) Picia syriaca, male; (d) Stenopelmus rufinasus, female; (e) S. rufinasus, head, female; (f) Arthrostenus fullo, male; (g) Aorus anthracinus, male (not on the same scale). 

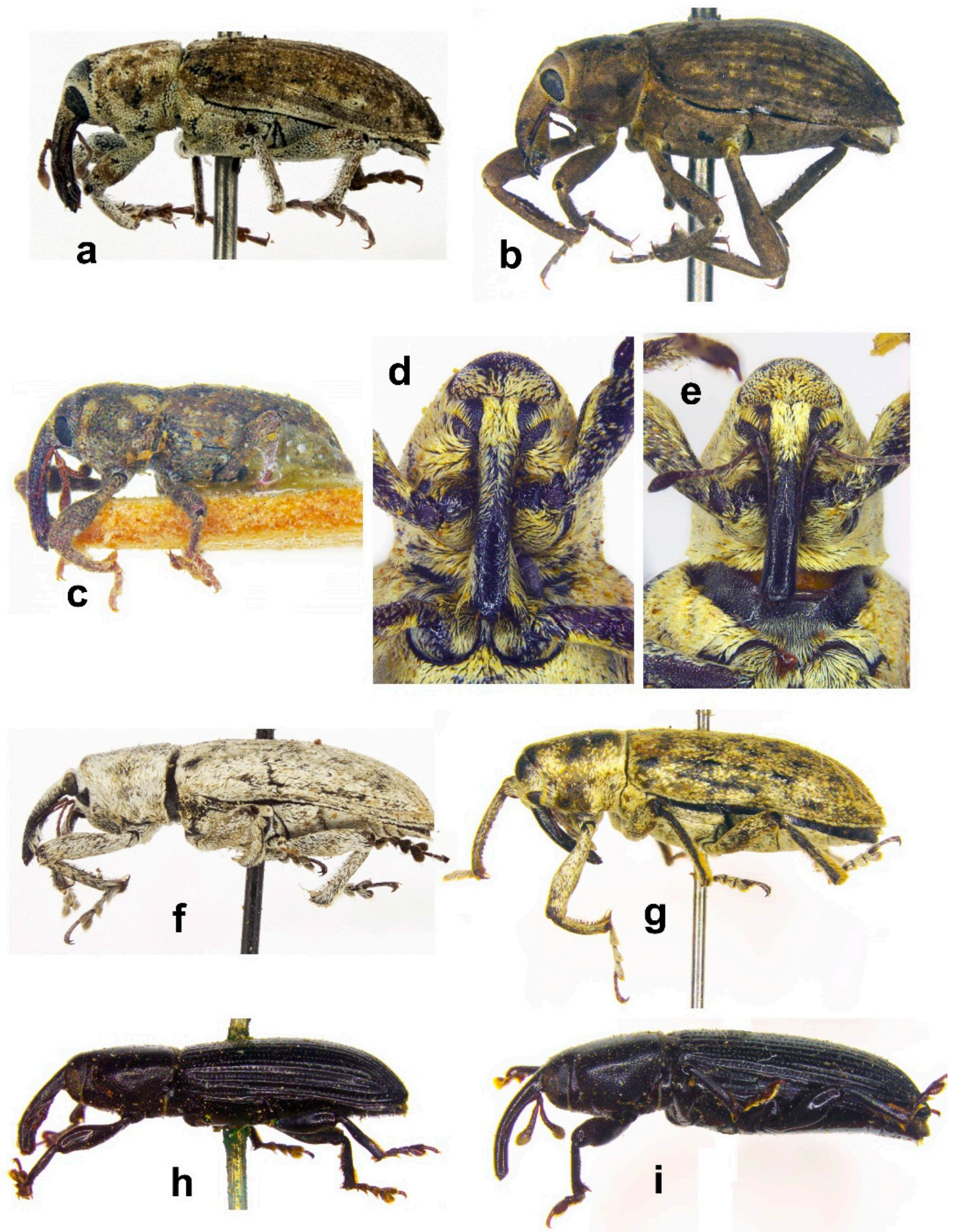

Figure 11. Habitus (a) Icaris sparganii, male, lateral view; (b) Picia syriaca, male, lateral view; (c) Echinocnemus reitteri, female, lateral view; (d) Arthrostenus fullo, head and pronotum, male, ventral view; (e) A. fullo, head and pronotum, female, ventral view; (f) A. fullo, male, lateral view; (g) A. fullo, female, lateral view; (h) Aorus anthracinus, male, lateral view; (i) A. anthracinus, female, lateral view (not on the same scale). 
Picia syriaca (Reitter, 1889) [104]

(Figures $4 \mathrm{~d}, \mathrm{e}, 10 \mathrm{c}, 11 \mathrm{~b}$ and 13a)

Material Examined: 8 exx.

ISRAEL: Central Coastal Plain: Berekhat Ya'ar, 14.v.2003, L. Friedman (1 female), 23.v.2003, A. Freidberg (1 male, 1 female); Netanya, pool, 4.iii.2005, A. Gasith (1 female); Ga'ash, 14.iv.1973, D. Furth (1 male, 3 females); Tel Aviv, Sharona [Sarona], ii.1904, J. Sahlberg (1 male, 1 female, ZSMU, ex collection of K. Daniel).

Distribution: East-Mediterranean (Greece, Cyprus, Turkey, Syria, Israel) $[45,84]$. Described from Israel. In Israel found in the winter vernal pools along the Central Coastal Plain.

Biology: Aquatic. Host plant unknown. The specimens from Berekhat Ya'ar (Figure 4a) in May 2003 were collected together with Icaris sparganii. The larvae of Picia sinuatocollis Faust, 1885 (recorded under its junior synonym alfierii Pic) in Egypt feed on rice roots in rice swamps [87], which might suggest the same or similar habits in P. syriaca. Adults active in February-May.

Notes: Picia syriaca was recorded by Sahlberg [93] as Hydronomus sinuaticollis Faust; he collected 19 specimens in the Sarona German Templer agricultural colony, which is today one of the neighborhoods in the center of the Tel Aviv megapolis. I studied two specimens deposited in ZSMU.

The first specimen of $P$. syriaca I had ever seen was brought to me alive from Berekhat Ya'ar by Prof. Avital Gasith in April 2002. I was fascinated by its swimming abilities-it swam easily and elegantly in a glass jar, where it was photographed by Amikam Shoob, the then photographer of the Department of Zoology, Tel Aviv University (Figure 4d,e). Planning to photograph it swimming the next day, I covered the jar with a lid with a metal mesh window. Next morning, I found that somebody had removed the lid and the weevil had disappeared, proving —alas— that it was able to fly.

Arthrostenus Schoenherr, 1826 [105]

Comprises nine semi-aquatic species in warm and arid parts of the Palaearctic region (East Mediterranean, Caucasus, Middle Asia) [45,91]. Associated with Poaceae, Sparganiaceae, and Typhaceae [91,106].

Arthrostenus fullo Boheman, 1836 [107]

(Figures 10f, 11d-g and 13c)

Material Examined: 22 exx.

ISRAEL: "69" (2 females); Hula Valley: Tel Dan, 27.v.1959 (1 female); Dan, 12.vi.1958 (1 male); Sede Nehemya, 23.v.1957, Y. Palmoni (1 male); Sede Nehemya [Hulioth], 18.v.1956 (1 female), 14.vi.1958 (2 males); Lahavot haBashan [L'havoth Habashan], 7.vi.1958, L. Fishelsohn (1 female), 28.v.1975, Z. Shoham (1 male); Hula, 13.vi.1954, L. Fishelsohn (1 male, 1 female), Y. Palmoni (1 female), 30.v.1956 (2 males, 2 females); 'Enot 'Enan [Malaha], 13.vi.1954, on Phragmites (2 females); Hulata, 10.v.19??, H. Bytinsky-Salz, on Typha (1 male, 1 female), 11.ii.1956 (1 female); Northern Coastal Plain: Shave Ziyyon, 24.viii.1971, Z. Shoham (1 male); Central Coastal Plain: ?Kefar Vitkin, ?summer 1945, H. Nemlokh (1 male).

Distribution: Recorded from South-East Europe (Greece, South of the European part of Russia, Ukraine), Caucasus (Armenia), Middle East (Syria) and Middle Asia (Turkmenistan) [45].

Recorded from Israel by Friedman [4]. In Israel was common in the Hula Valley (until the drainage of the Hula Lake in the 1950s) and in the swamps along the Mediterranean coast, but has not been re-collected since the 1970s. This either suggests a strong decrease in the population size or even an extinction of this species in Israel, mainly due to loss of the appropriate biotope. 
Biology: Semi-aquatic. Develops on Phragmites australis (Cav.) Trin. ex Steud. (Poaceae) [104]. In Israel was collected on Phragmites australis (Figure 2c) and Typha sp. (probably the most common T. domingensis (Pers.) Steud.) (Typhaceaceae) (the last record is somewhat doubtful, probably based on an uncertain identification of the plant). Adults were collected all year round, but predominantly in June-August.

Notes: The male of $A$. fullo possesses a peculiar moustache comprising long woolly setae on its prorostrum, while the female lacks this character (Figure 11d,e).

The specimens collected by Ze'ev Shoham, an amateur moth researcher, were collected in light traps, and these are also the most recent collected specimens. Light trapping in the Hula Valley and the wetlands of the Northern Coastal Plain (e.g., 'En Afeq Nature Reserve, 'En Nimfit Nature Reserve (Figure 4c), 'Akko swamp) might therefore reveal the existence of the remaining population of $A$. fullo.

Tanysphyrini Gistel, 1848 [49]

Stenopelmus Schoenherr, 1835 [108]

A Nearctic genus comprising three aquatic species distributed in USA, Central and South America, one of them introduced occasionally into Europe and Japan and deliberately into South Africa, associated with the water ferns Azolla (Salviniaceae) [45,91]. In Israel, it is represented by a single species, probably introduced occasionally with an ornamental Azolla.

Stenopelmus rufinasus Gyllenhal, 1835 [95]

(Figures 10d,e and 13c)

Material Examined: 2 exx.

Israel: Central Coastal Plain: Berekhat Ya'ar Nature Reserve, 20.vii.2010, 32 $24^{\prime} 39^{\prime \prime} \mathrm{N} 34^{\circ} 45^{\prime} 02^{\prime \prime}$ E, L. Friedman, C. Drees, pitfall trap ( 1 female); Central Negev: Nahal Qarqash, opposite to the entrance to Midreshet Sede Boqer, $30^{\circ} 51^{\prime} 15^{\prime \prime}$ N $34^{\circ} 46^{\prime} 08^{\prime \prime}$ E, 13.iv.2010, L. Friedman, C. Drees, pitfall trap (1 female).

Distribution: Nearctic. It was occasionally introduced with ornamental Azolla in Western Europe, Japan and Israel $[109,110]$ and deliberately introduced into southern Africa for biocontrol of Azolla [91,111]. In Israel collected with pitfall traps only in 2010. The escape of Azolla from an aquatic plants farm into Berekhat Ya'ar in 2010 was recorded by Dufour-Dror [112], and could be the source of a specimen collected there. The reason for the appearance of S. rufinasus in the Central Negev desert, at the bottom of the upper Nahal Qarqash, opposite the entrance to Midreshet Sede Boqer, an extremely dry place lacking any natural or artificial water body, is completely unclear. However, there is a nursery in Midreshet Sede Boqer, coincidentally named Mishtelet Qarqash (Karkash Nursery, https://www.karkash.com/), which could be a sourse of Azolla. It is unclear whether the weevil has become established in Israel or has disappeared.

Biology: Aquatic. Monophagous on Azolla spp. (e.g., Azolla filiculoides, A. caroliniana) (Salviniaceae) [70,91].

Molytinae Schoenherr, 1823 [43]

Amalactini Lacordaire, 1863 [113]

Aorus Schoenherr, 1835 [108]

An Afro-Oriental genus comprising eight species [30,37,114]. The larvae of Aorus were recorded burrowing in the stems of Cyperus and Scirpus (Cyperaceae) and Pennisetum (Poaceae), and adults feeding on grasses [30]. Marshall [114] reported the mass appearance of adults of A. ferrugineus Boheman on ears of rice in Vietnam. In Israel, Aorus is represented by an African species, and is the northernmost point of its distribution. 
Aorus anthracinus Brancsik, 1898 [115]

(Figures 10g, 11h,i and 13c)

Material Examined: 19 exx.

ISRAEL: Hula Valley: Hula [Hulah], 5.vii.1934, F. S. Bodenheimer, in Papyrus (1 female), [Huleh], 12.iii.1946, H. Bytinski-Salz (1 male, 2 females), 10.v.19??, H. Bytinski-Salz, in Papyrus (4 males, 5 females), viii.19??, H. Bytinski-Salz, in Papyrus (4 males, 5 females); ?Central Coastal Plain: Kabara swamp? (1 ex., Berkovitch Collection, Ma'agan Mikha'el).

Distribution: Afrotropical (Senegal, Uganda, Mozambique, Zambia) [114]. In the Palaearctic region recorded only from Israel [37], although not collected since the 1950s, and therefore considered extinct [4]. All specimens in the SMNHTAU come from the warm and humid swamps of the Hula Valley, the northernmost tip of the Rift Valley. I found an unlabeled specimen of A. anthracinus in the private collection of the late Dov Berkovitch in Kibbutz Ma'agan Mikha'el. I was able to talk to Mr Berkovitch a couple of years before he passed, but he was not able to recall collecting this specimen while nevertheless insisting that his collection was mainly from the surroundings of Ma'agan Mikha'el, including the Kabara swamp, recently drained. Therefore, I assume that this specimen might have been collected in the Kabara swamp, indicating its occurrence also in the coastal swamps.

Biology: Most of the specimens were collected on Cyperus papyrus L. (Cyperaceae) (Figure 3d), which is most likely its host. This corresponds well with the knowledge on the other species of Aorus [114]. The 3rd tarsal segment of $A$. anthracinus has wide round lobes, pilose beneath, suggesting it climbs on plants better than it swims, the body is completely glabrous, devoid of any scales or therefore I assume it is semi-aquatic.

Conoderinae Schoenherr, 1833 [116]

This subfamily is distributed worldwide except the polar regions, comprising 7571 species in 940 genera [117].

Ceutorhynchitae Gistel, 1848 [49]

This supertribe is distributed worldwide except for southern part of South America and Antarctica, comprising 1371 species in 175 genera [117]. The study of the Israeli Ceutorhynchitae is still incomplete, but I estimate that there are approximately 100 species. Israeli Ceutorhynchitae are mainly monophagous or narrow-oligophagous, predominantly on species of the plant families Amaranthaceae, Anacardiaceae, Boraginaceae, Brassicaceae, Caryophyllaceae, Chenopodiaceae, Ephedraceae, Fabaceae, Fagaceae, Lamiaceae, Liliaceae, Papaveraceae, Polygonaceae (listed in alphabetical order). Ceutorhynchitae comprise numerous aquatic and semi-aquatic species and genera [117-120]; however, in Israel, only two species of Rhinoncus are found in aquatic habitats.

Phytobiini Gistel, 1848 [49]

This is the largest tribe among Ceutorhynchitae and the most widely distributed, lacking in tropical America [117]. Most of its representatives are aquatic or semi-aquatic [7,121].

Rhinoncus Schoenherr, 1825 [82]

Comprises 36 species in Palaearctic, Nearctic, Afrotropical, Oriental and Australasian regions. Those whose biology is known are associated with Polygonaceae (Persicaria, Polygonum, Rheum, and Rumex) [118].

Rhinoncus pericarpius (Linnaeus, 1758) [122] (Figures 12a,c and 13d)

Material Examined: 11 exx. 
ISRAEL: Golan Heights: Panyas, Upper [Baniass Up.], 5.iv.1978, D. Furth (1 female); Yehudiyya Nature Reserve [Qusbiye], 21.ii.1974, D. Furth (1 female); Carmel Ridge: 'En haShofet, 23.iii.1973, D. Furth (1 female); Central Coastal Plain: Berekhat Ya'ar, 14.v.2003, L. Friedman (1 female); Berekhat Ya'ar, South, 23.v.2003, L. Friedman (1 female); Berekhat Ya'ar, $32^{\circ} 24^{\prime} 39^{\prime \prime} \mathrm{N} 34^{\circ} 45^{\prime} 02^{\prime \prime}$ E 16.iii.2010, L. Friedman, C. Drees, pitfall (3 males, 3 females).

Distribution: Holarctic (excluding North Africa) $[45,118]$. First record for Israel and for the Middle East. In Israel collected rarely and locally on the banks of mountain streams (Panyas, Yehudiyya, 'En haShofet) and Berekhat Ya'ar vernal pond. The localities have little in common, making it unclear which is its preferred microhabitat.

Biology: Presumably semi-aquatic. On Rumex spp., Polygonum spp., Rheum rhabarbarum L. (Polygonaceae) [118]. Host in Israel unknown. Adults active in February-April.

Note: R. pericarpius occurs in Israel at the southernmost border of its distribution. Only five specimens were collected by sweeping during the last 45 years, while six specimens were collected in pitfall traps during one collecting event. I assume that $R$. pericarpius is not as rare as it might appear to be, but is either nocturnal (avoiding high temperatures during the daytime) or lives on low, creeping plants along the water edge, which are difficult to sweep (or both).

Rhinoncus perpendicularis (Reich, 1797) [123] (Figures 12b,d,e and 13d)

Material Examined: 93 exx.

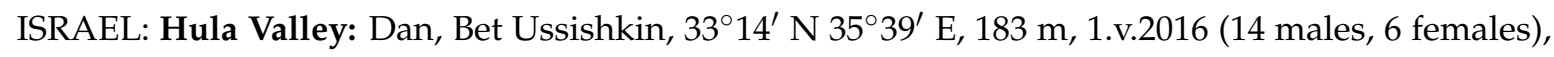
7.v.2017 (2 males); Gonen, 18.vi.1973, D. Furth (3 males); 'Enot ‘Enan, $33^{\circ} 5^{\prime}$ N 35 35 $35^{\prime}$ E, 4.x.2001, L. Friedman ( 1 female); 'Enot ‘Enan, 1.v.2006, L. Friedman (1 male, 3 females), 13.vii.2011, L. Friedman (2 males); Hula Nature Reserve, 13.vii.2011, D. Furth (1 male); Park haYarden, 17.v.2009, L. Friedman (3 males, 2 females); Park haYarden, $32^{\circ} 55^{\prime} \mathrm{N} 35^{\circ} 38^{\prime}$ E, -200m, 19.vii.2009, L. Friedman (8 males, 1 female); Park haYarden, $32^{\circ} 54.5^{\prime}$ N 35 37. $5^{\prime}$ E, -210 m, 19.vii.2011, L. Friedman (1 female); Park haYarden, -200 m, 18:00-21:00, 17.viii.2014, L. Friedman, on Persicaria decipiens (=salicifolia) (22 males, 8 females), 24.viii.2016, L. Friedman, on Persicaria decipiens (6 males, 4 females); Sea of Galilee Area: Gesher Arik, N. Kinneret, 19.vi.2012, L. Friedman (1 male); Bet Zayda Nature Reserve, Nahal Yehudiyya spill, 13.ix.2011, Z. Yanai (1 female); Ma'agan Island, South Kinneret, 23.xi.2009 (1 female); Central Coastal Plain: Meqorot haYarqon, Nufarim Pool, 1.xii.2005, T. Eshkoli (1 male); Southern Coastal Plain: Ashdod Port, 5620, 3.xi.2016, PPIS, on wood from Ukraine, under bark (1 male).

Distribution: Palaearctic, introduced into North America [4,31]. First record for Israel. In Israel it is very common in the Hula Valley, occurs locally also around the Sea of Galilee and along the Coastal Plain, on the banks of any constant water source (streams and ponds), but not in vernal ponds.

Biology: Semi-aquatic. On Persicaria spp., Polygonum spp., occasionally on Rumex spp. [118,120]. In Israel on Persicaria decipiens (R.Br.) K.L. Wilson (Figure 3e), larvae develop in rootstalk knots. The host plant is found in the shallow waters along the shore. Adults active all year round, but mainly in May-September, more active in the evening and early night, when the temperature drops, and then can be easily collected on the host plant. Semi-aquatic. Adults are able to swim. The abdominal sternites, particularly the last abdominal segment, bear longer thin erect hairs (Figure 12e), characteristic of different aquatic weevils, which probably take part in air-breathing of the weevil in the water. Adults probably active all year round. 

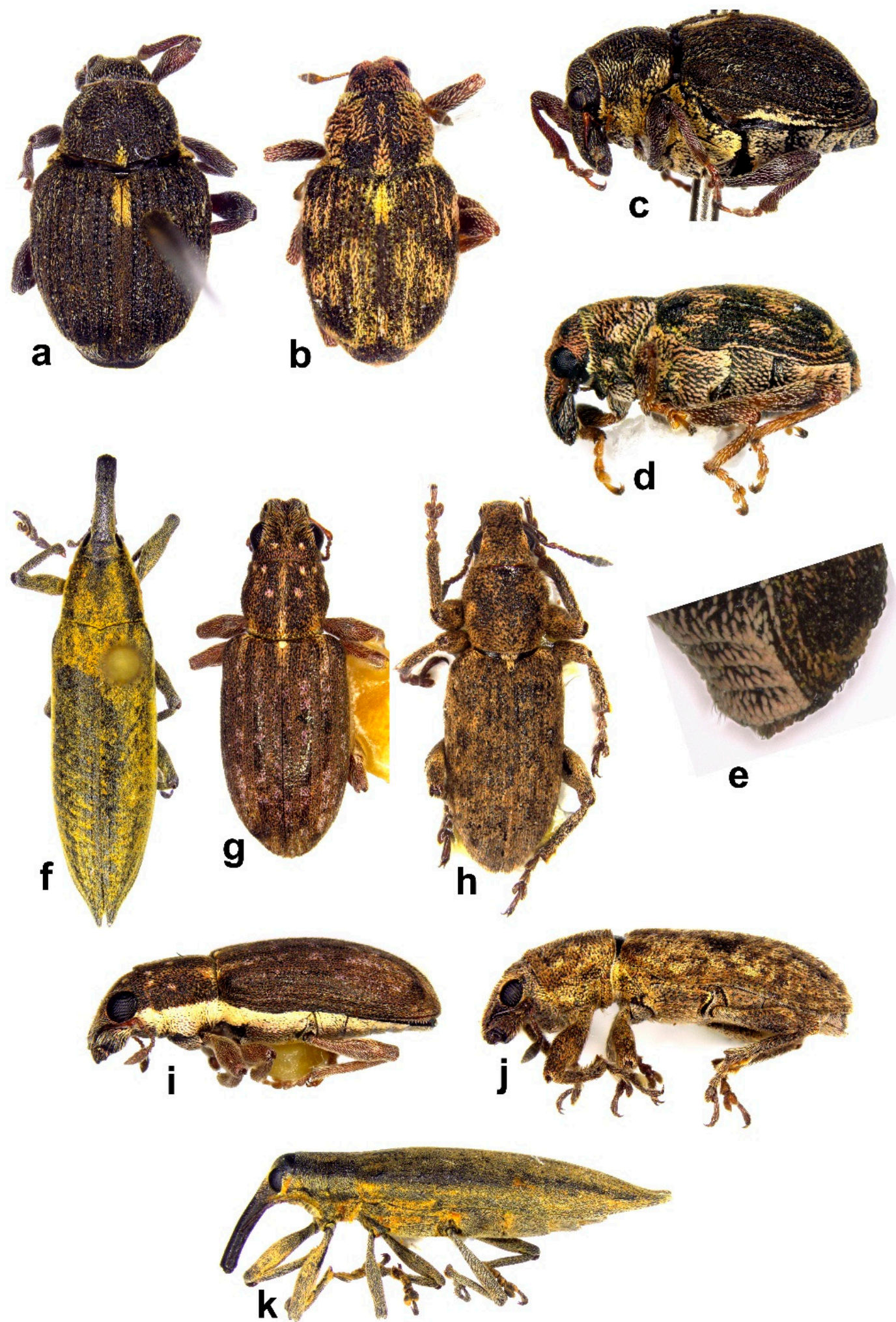

Figure 12. Habitus (a) Rhinoncus pericarpius, male, dorsal view; (b) R. perpendicularis, male, dorsal view; (c) R. pericarpius, male, lateral view; (d) R. perpendicularis, male, lateral view; (e) R. perpendicularis, male, abdominal sternites, lateral view; (f) Lixus iridis, male, dorsal view; (g) Sitona lividipes, male, dorsal view; (h) Tanymecus musculus, male, dorsal view); (i) S. lividipes, male, lateral view; (j) T. musculus, male, lateral view); (k) L. iridis, female, lateral view. 

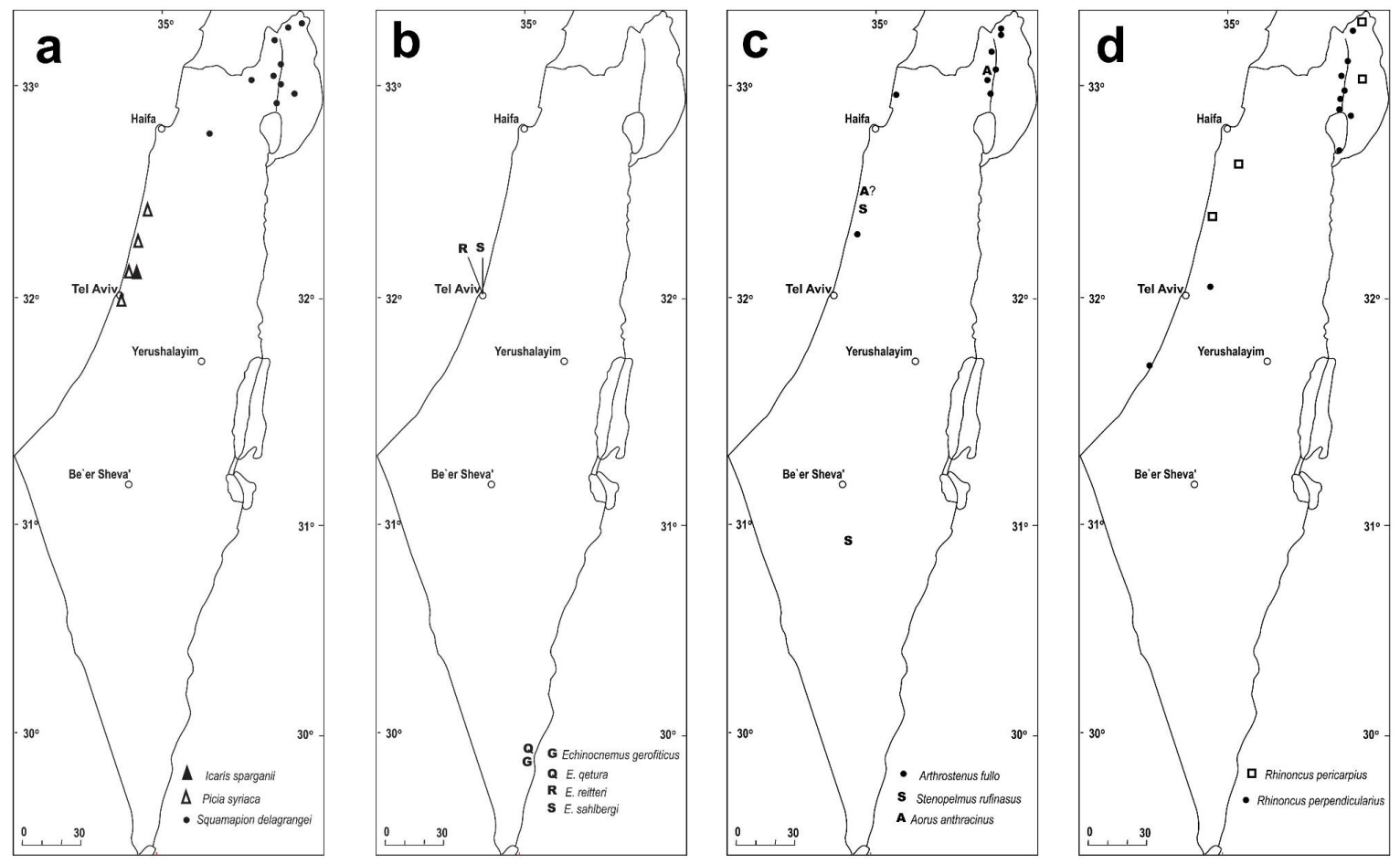

Figure 13. Distributional maps of (a) Icaris sparganii, Picia syriaca, Squamapion delagrangei; (b) Echinocnemus reitteri, E. sahlbergi, E. gerofiticus, E. qetura; (c) Arthrostenus fullo; Stenopelmus rufinasus, Aorus anthracinus; (d) Rhinoncus pericarpius, R. perpendicularis.

Curculioninae Latreille, 1802 [60]

Mecinini Gistel, 1848 [49]

Comprises six genera with ca. 250 species in the Old World, mainly associated with Scrophulariaceae, Plantaginaceae, and Campanulaceae [62]. All six genera are represented in Israel [45].

Gymnetron, Schoenherr, 1825 [82]

This genus comprises ca. 100 species in the world and 33 in the Palaearctic region with four species recorded for Israel [45,62]. In Israel associated with Scrophularia, Verbascum and Veronica (Scrophulariaceae).

Gymnetron niloticum Kirsch, 1881 [124] (Figure 2d,e, Figure 14a,b,e and Figure 15b)

Material Examined: 39 exx.

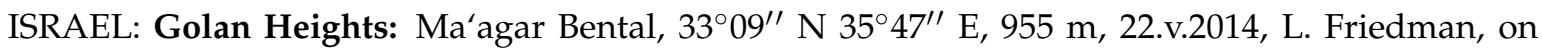
Veronica anagallis-aquatica (1 female); Hula Valley: Park haYarden, $32^{\circ} 55^{\prime} \mathrm{N} 35^{\circ} 38^{\prime}$ E, 2.iii.2010, A. Freidberg (1 female); Carmel Ridge: 'En haShofet, 23.iii.1973, D. Furth (1 female); Samaria: Barqay [Barkai], 9.v.1978, D. Furth (2 males); Nahal Qana Nature Reserve, 26.ii.2014, L. Friedman, on Veronica anagallis-aquatica (6 males, 4 females); Nahal Qana Nature Reserve, 'En Tanur, Turtles' Pond, iv.2018, L. Friedman, on Veronica anagallis-aquatica (12 males, 6 females); Central Coastal Plain: Zikhron Ya'aqov, 1.iv.1997, R. Hoffman (1 female); Sedot Yam, 4.v.1998, M. Fine (1 male); Lehavot Haviva, 14.vi.1977, J. Halperin, on Prunus passardi (1 male, 3 females).

Distribution: South-East Europe, North Africa, Caucasus, Middle East, Middle Asia [45,125]. In Israel single specimens were occasionally collected on the Golan Heights, in the Hula Valley, on and at the foot of the Carmel Ridge and in the Central Coastal Plain. I recently found a large dense population of 
G. niloticum in Nahal Qana (Qana Stream) in the Samarian Hills, on its host plant along the water edge (Figure 2d,e).

Biology: Riparian. On Veronica spp. (Scrophulariaceae) [125]. In Israel monophagous on Veronica anagallis-aquatica L. (Figure 2e). Adults active in February-June.

Gymnetron tibiellum Desbrochers des Loges, 1900 [126]

(Figures 14c,d,f and 15b)

Material Examined: 164 exx.

ISRAEL: Golan Heights: Panyas, $33^{\circ} 14^{\prime} 55^{\prime \prime}$ N $35^{\circ} 41^{\prime} 40^{\prime \prime}$ E, 20.vii.2009, L. Friedman (5 males, 7 females); Ma'agar Bental, 12.v.2014, L. Friedman (1 male, 2 females); Upper Galilee: Ga'ton, 6.ii.2000, L. Friedman (1 male); Hula Valley: Dan, 22.v.2002, L. Friedman, on Veronica anagallis-aquatica (30 exx.), 27.v.2003, L. Friedman, on Veronica anagallis-aquatica (14 males, 21 females), 25.v.2005, L. Friedman (11 males, 19 females), 2.vi.2008, L. Friedman (1 male, 2 females + unsexed 24 exx.); Park haYarden,

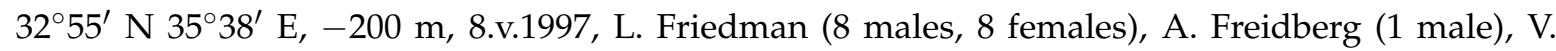
Chikatunov (1 male, 2 females), 17.v.2009, L. Friedman (2 females), 19.vii.2009, L. Friedman (1 female); Samaria: Har Berakha, 'Amassa Springs, 4.iv.2013, L. Friedman (1 female); Carmel Ridge: Nahal Tut, Hagit Forest [Tut Hagit], Y. Hershkovitz (1 male); Foothills of Judea: Park Canada, 29.v.1987, Y. Zvik (1 male).

Distribution: South-east Europe, Caucasus, south-west Asia [45,125]. In Israel very common in the low humid Hula Valley and relatively humid and high northern part of the Golan Heights, occasionally occurs in the highlands of the Upper Galilee, Carmel Ridge, Samarian and Judean Hills. Occurs on banks of streams and ponds.

Biology: Riparian. Monophagous on Veronica anagallis-aquatica L. (Scrophulariaceae) (Figure 2e), first record of the host plant. Adults active in April-July, but mainly in May.

Tychiini C. G. Thomson, 1859 [61]

This tribe is distributed worldwide except Australasia, associated with Aizoaceae, Caryophyllaceae, Fabaceae, Moraceae, Oleaceae, Plumbaginaceae [62].

Tychius Germar, 1817 [65]

Comprises 227 species in the Palaearctic region, with 24 species recorded for Israel, all associated with Fabaceae [45,62].

Tychius bicolor C. N. F. Brisout de Barneville, 1863 [127]

(Figures 14g,i-k and 15c)

Material Examined: 46 exx.

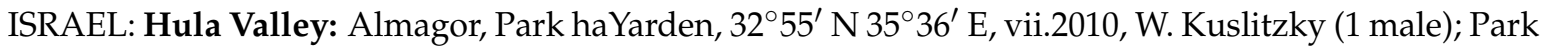
haYarden, 8.v.1997, L. Friedman (7 males, 5 females), A. Freidberg (1 female), V. Chikatunov (1 female); Park haYarden, $32^{\circ} 54.5^{\prime} \mathrm{N} 35^{\circ} 38^{\prime}$ E, $-210 \mathrm{~m}, 14 . i v .2011$, E. Morgulis (2 males); Park haYarden, -200 m, 18:00-21:00, 17.viii.2014, L. Friedman, on Melilotus albus (13 males, 11 females), 24.viii.2016, L. Friedman, on Melilotus albus (1 male); Sea of Galilee Area: Hof Rotem-Shezaf, 3kmS 'En Gev, -200 $\mathrm{m}, 32^{\circ} 46^{\prime} \mathrm{N} 35^{\circ} 38.3^{\prime}$ E, A. Freidberg (1 male, 1 female); Northern Coastal Plain: 'En Nimfit Nature Reserve, Migdalit haNehalim Pond, 15.iii.2018, L. Friedman, on Melilotus (1 female); Southern Coastal Plain: Palmahim, vi.1961, Katznelson (1 male, 1 female).

Distribution: Mediterranean $[45,128]$. In Israel occurs mainly in the Hula Valley, but also around the Sea of Galilee and along the Coastal Plain, at least in the past reaching its southern part. On the banks 
of Nehar haYarden (=Jordan River) and its tributaries (Figures $1 \mathrm{f}$ and $2 \mathrm{c}$ ) and in the coastal swamps (Figure 4c). T. bicolor occurs in Israel within its normal range of distribution.

Biology: Riparian. On Melilotus officinalis (L.) Pall., M. segetalis (Brot.) Ser. (=leiosperma Pomel.), Astragalus monspessulanus L. (Fabaceae) [128]. In Israel on Melilotus albus Medik. ex Desr. Adults active in March-August.

Tychius meliloti Stephens, 1831 [129]

(Figures 14h,l-n and 15c)

Material Examined: 107 exx.

ISRAEL: Hula Valley: Nahal Senir Nature Reserve, 21.viii.2012, L. Friedman (1 male); Park haYarden, 8.v.1997, L. Friedman (13 males, 1 female), A. Freidberg (1 male); Park haYarden, -200 m, 18:00-21:00, 17.viii.2014, L. Friedman, on Melilotus albus (34 males, 43 females); 24.viii.2016, L. Friedman, on Melilotus albus (6 males, 1 female); Sea of Galilee Area: Gesher Arik, HaYarden, 17.viii.2014, L. Friedman (3 males, 3 females); 'En Gev, 10 kmN, 8.v.1997, L. Friedman (1 female).

Distribution: Palaearctic, introduced in Afrotropical and Nearctic regions [45]. Was recorded from Israel by Caldara $[97,128]$, but omitted by Alonso-Zarazaga et al. [45]. Here it is returned to the weevil list of Israel. In Israel occurs only in the Hula Valley (common) and around the Sea of Galilee (rare), being at its southernmost border of distribution. Occurs on its host plant on the banks of Nahar haYarden (= Jordan River) and its tributaries (Figures 1f and 2c).

Biology: Riparian. Melilotus altissimus Thuil., M. officinalis (L.) Pall., M. albus Medik. (Fabaceae) [128]. In Israel on Melilotus albus Medik. ex Desr. Adults active in May-August.

Entiminae Schoenherr, 1823 [43]

Entiminae comprises about 1370 genera with above 12,000 species, distributed worldwide, including sub-Antarctic regions [130]. Larvae usually develop in soil, on the plant roots, adults feed on green parts of plants. Entiminae are mostly polyphagous or wide-oligophagous, associated with dicotyledons, monocotyledons, gymnosperms and even ferns, but an enormous number of species are associated with Fabaceae [130].

Sitonini Gistel, 1848 [49]

This tribe is distributed in Holarctic realm, South Africa, Madagascar and south-east Asia, associated with Fabaceae and Mimosaceae [37,131]. Twenty-three species in four genera are recorded for Israel [132].

Sitona Germar, 1817 [65]

Sixteen species are recorded from Israel in this genus, all associated with wild or cultivated Fabaceae [132]. 

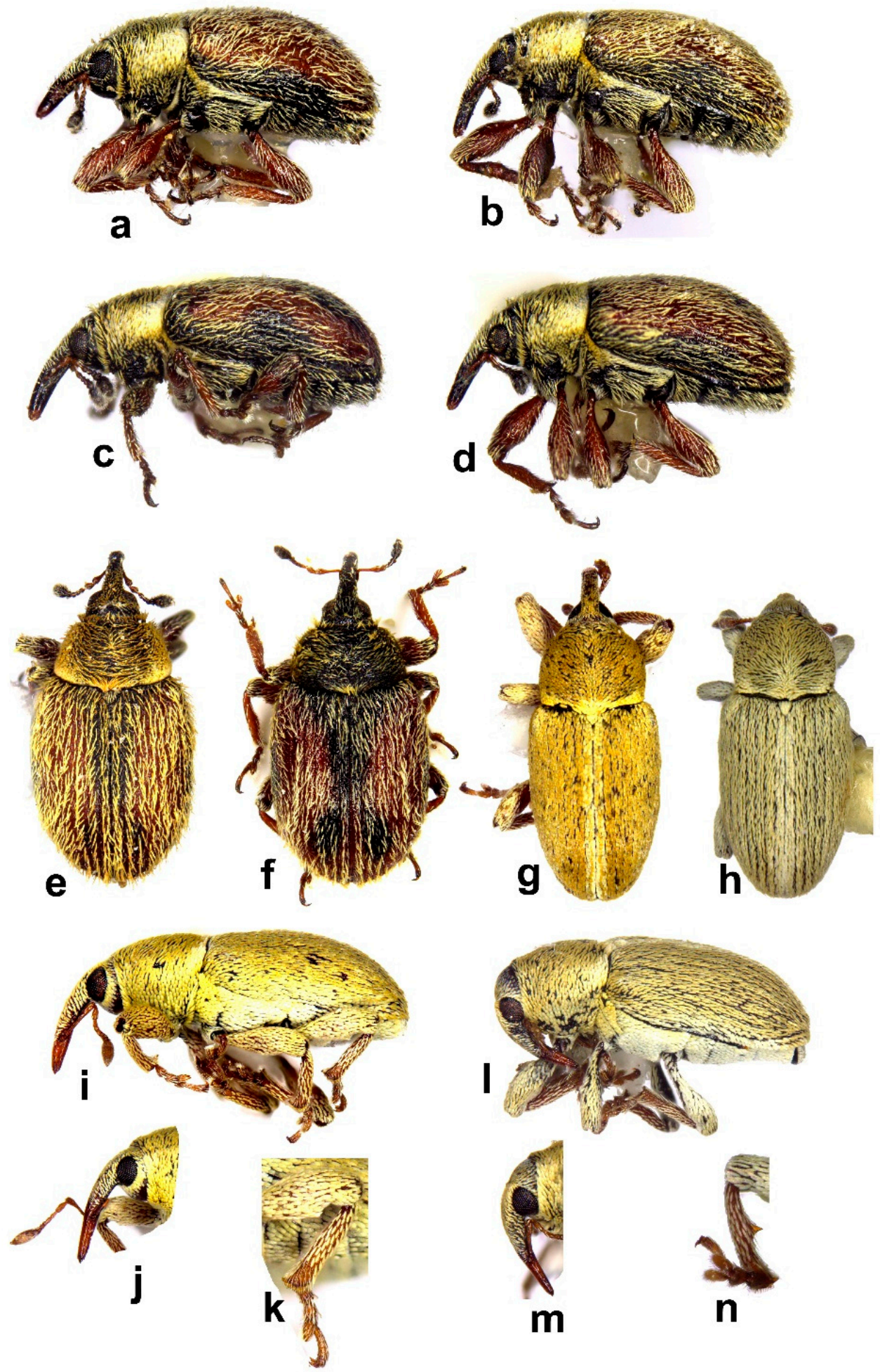

Figure 14. Habitus (a) Gymnetron niloticum, male, lateral view; (b) G. niloticum, female, lateral view; (c) Gymnetron tibiellum, male, lateral view; (d) G. tibiellum, female, lateral view; (e) G. niloticum, male, dorsal view; (f) G. tibiellum, male, dorsal view; (g) Tychius bicolor, male, dorsal view; (h) T. meliloti, male, dorsal view; (i) T. bicolor, male, lateral view; (j) T. bicolor, female, lateral view; (k) T. bicolor, hind leg, male; (1) T. meliloti, male, lateral view; (m) T. meliloti, female, lateral view; (n) T. meliloti, fore tibia, male (not on the same scale). 

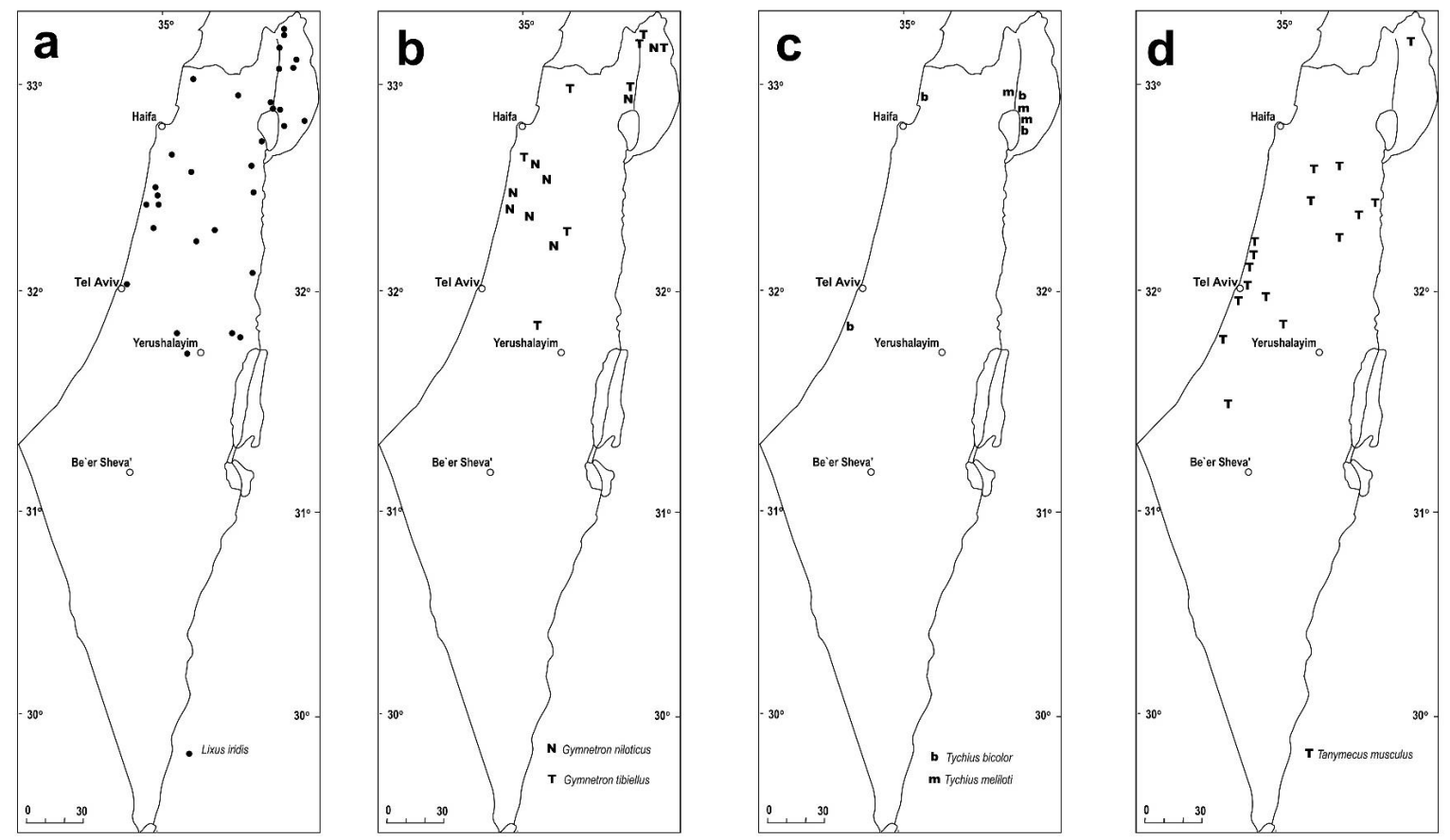

Figure 15. Distributional maps of (a) Lixus iridis; (b) Gymnetron niloticum, G. tibiellum; (c) Tychius bicolor, T. meliloti; (d) Tanymecus musculus.

Sitona lividipes Fåhraeus, 1840 [133]

(Figure 12g,i)

Material Examined: 108 exx.

ISRAEL: Hermon: Har Hermon, 1600 m, 20.v.1997, L. Friedman (1 female), 12.vi.2003, A. Freidberg (1 male); Nabi Hazuri, $33^{\circ} 15^{\prime \prime}$ N $35^{\circ} 44^{\prime \prime}$ E, 18.x.2009, L. Friedman (1 male); Golan Heights: Panyas [Baniass Up.], 8.iv.1978, D. Furth (1 female); Panyas [Banias], 25.v.1982, J. Halperin, on Salix (3 exx.); Panyas, 16.v.2003, V. Kravchenko, light trap (1 female); Panyas Hydrometric Station, 4.iii.2001, L. Friedman (2 males; 1 male); Berekhat Ram [Birket Ram], 27.iv.1978, D. Furth (1 female); El-Rom, 15.vi.2002, V. Kravchenko, light trap (1 female); Merom Golan, Bental Reservoir, $33^{\circ} 08^{\prime \prime} \mathrm{N} 35^{\circ} 47^{\prime \prime} \mathrm{E}$, 30.iv.2006, L. Friedman (1 male), 7.v.2006, L. Friedman (1 female); Ma'agar Bental, $33^{\circ} 08^{\prime \prime} \mathrm{N} 35^{\circ} 47^{\prime \prime}$ E, 7.v.2007, L. Friedman (1 male), 1.vi.2008, L. Friedman (1 female); Qazrin, 4.v.1999, L. Friedman (2 males), 21.v.2002, L. Friedman (1 female); Yehudiya Forest Nature Reserve [Qusbiye], 17.xi.1973, D. Furth (1 female), 28.iv.1974, D. Furth (1 male), 4.v.1979, D. Furth (1 male); Hula Valley: Tel Dan, 20.vii.1983, Y. Zvik (1 male); Nahal Senir, 24.v.1999, L. Friedman (1 male; 2 females); Sede Nehemya [Huliot], 20.v.1968 (3 males, 3 females); Amir, 5.iv.1978, D. Furth (1 male); Shamir, 5.vi.1984, J. Halperin, on Fraxinus syriacus (2 females); Hula, 5.vi.1974, D. Furth (1 male, 2 females); Gadot, $25 \mathrm{~km}$ N Tiberias, 8.vi.1971, S. Bet-Aharon (1 male); Mahanayim, 17.xi.1974, D. Furth (1 male); Upper Galilee: Nahal Keziv, 1.i.1999, M. Finkel (1 female); 'En Ya'aqov, 12.vi.2006, I. Shtirberg (1 female); Har Meron, 1100, $32^{\circ} 59^{\prime \prime}$ N $35^{\circ} 25^{\prime \prime}$ E, 22.xi.2006, L. Friedman (1 male; 2 females), A. Freidberg (1 female); Har Meron [Mt. Meron], 12.vii.2002, V. Kravchenko, light trap (1 male); Har Meron, 2006, H. Tsegai (1 male); Nahal 'Ammud [N. Amud], 30.iv.1978, D. Furth (2 males); Lower Galilee: Nazeret [Nazareth], 30.ix.1982, Q. Argaman (1 male); Carmel Ridge: Nahal Oren, 17.xi.1997, V. Chikatunov, T. Pavliček (1 male), 15.xii.1997, V. Chikatunov, T. Pavliček (1 male); Nahal Tut [N. Tut], 4.v.1978, D. Furth (1 female); Jordan Valley: Biq'at Bet Zayda [Btecha], 18.x.1971, A. Goldstein (1 female); Park haYarden, 17.v.2009, L. Friedman (2 males, 1 female); Kursi, 15.xii.1972, D. Furth (3 males); Ashdot Ya'aqov [Ashdot Yaacov], 27.vii.1972, A. Goldstein (1 male); Yizre'el Valley: ‘En Harod [Ein Charod], 9.x.1948, H. Bytinski-Salz 
(1 male, 1 female); Tel Yosef, 9.xii.1939, on Trifolium (1 male); Central Coastal Plain: Ma'agan Mikha'el, 4.v.1998, A. Freidberg (1 male, 2 females); Binyamina, 25.i.1997, R. Hoffman (1 male); Hadera, 16.xi.1973, D. Furth (2 males), 28.iv.1979, D. Furth (1 male); Berekhat Ya'ar, 14.v.2003, L. Friedman (2 males, 2 females), 28.iv.2004, L. Friedman (1 female), A. Freidberg (1 male); Ramat haSharon, $32^{\circ} 08^{\prime \prime} \mathrm{N} 34^{\circ} 50^{\prime \prime}$ E, 5.v.2007, D. Gerling, Malaise trap (1 male); Rosh ha'Ayin, 24.iii.1973, D. Furth (1 female); Southern Coastal Plain: Bet Dagan [Bet Dagon], 2.ii.1957, on Trifolium (1 male; 1 female), 21.xi.1957, on Trifolium (1 female); Bet Dagan, 26.xii.1956, on Trifolium (1 female; 1 male), 8.ii.1957, on Trifolium (1 female), 21.ii.1957, on Vicia (1 female); Yavne, 27.iv.1986, Q. Argaman (1 male, 1 female); Gan Shelomo [Kvuzat Shiler], 2.v.1958, E. Rivnay, on Medicago (2 female); Giv'at Brenner, xii.1959, Perez, Div. Plant. Prot. Dept. Agr. Israel, on Trifolium (12 exx.), 7.i.1951, H. Bytinski-Salz, on alfalfa (4 exx.); Gedera, 26.xi.1973, D. Furth (1 male, 1 female); Re'em Junction [Masmia], 16.i.1957, on Trifolium (2 male), 18.v.1957, on Trifolium (1 male; 1 female).

Distribution: Mediterranean [45]. In Israel occurs throughout the Mediterranean part of the country, very common.

Biology: This weevil also occurs in areas far from water sources, both temporary and permanent, although it is mostly common in humid ravines, on the banks of brooks, streams, and ponds, and comprises a considerable component in any riparian biotope. On Medicago spp. and Trifolium spp. (Fabaceae) [132]. Adults found all year round.

Tanymecini Lacordaire, 1863 [113]

Tanymecini are distributed worldwide, particularly in Neotropical region [37]. In Israel represented by three species (Friedman, unpublished data).

Tanymecus Germar, 1817 [65]

The genus is distributed in Holarctic, Neotropical, and Afrotropical regions [37], in Palaearctic region comprises 34 species [45]. Polyphagous, larvae live in soil on roots of different plants [120].

Tanymecus (Geomecus) musculus Fåhraeus, 1840 [133]

(Figures 12h,j and 15d)

Material examined: 166 exx.

ISRAEL: Golan Heights: Merom Golan, Ma'agar Bental = Bental Reservoir, $33^{\circ} 08^{\prime \prime} \mathrm{N} 35^{\circ} 47^{\prime \prime} \mathrm{E}$, 12.vi.2000, V. Chikatunov (6 exx.), 1.vi.2004, I. Zonstein (4 exx.), 25.v.2005, L. Friedman (35 exx.), 30.iv.2006, L. Friedman (2 exx.), 9.v.2006, L. Friedman (4 exx.), M. Meir (1 ex.), 7.v.2007, M. Orlova (1 ex.), K. Levi \& T. Huges Games (1 ex.), L. Younger \& E. Kauffmann (1 ex.), A Hahn \& O. Yelinek (1 ex.), 1.vi.2008, C. Bilu (1 ex.), S. Cohen (1 ex.), V. Liberman (1 ex.), W. Mansour (1 ex.), O. Pearlstein (1 ex.), 11.v.2010, L. Friedman (5 exx.), 11.v.2011, G. Dekel \& I. Gran (1 exx.), 14.v.2012, L. Friedman (11 ex.), on Eleocharis palustris (2 exx.), 7.v.2013, L. Friedman (12 exx.), A. Bespalko (1 ex.), R. Folkman (1 ex.), D. Tarhov (1 ex.), 12.v.2014, L. Friedman (8 exx.), 22.v.2014, L. Friedman (1 ex.), 11.v.2015, L. Friedman, on Eleocharis palustris (12 exx.); Jordan Valley: Ma'oz Hayyim, 4.vi.1971, Z. Shoham (1 ex.); Yizre'el Valley: 'Afula [Afoolah], 28.iii.1942, Bylinski-Salz (1 ex.); Newé Ya'ar, spring, on fields of legums, Y. Palmoni (3 exx.); Samaria: Ma'ale Gilboa', 8.vii.1982, Q. Argaman (1 ex.); Me 'Ammi, 2.iv.1985, on cotton, I. Susman (1 ex.); Nahal Tirza [W. Faria], 21.iii.1978, D. Furth (1 ex.); Central Coastal Plain: Netanya, 9.iii.1978, D. Furth (1 ex.); Ga'ash, 24.iv.1974, D. Furth, (1 ex.), 10.iii.1976, F. Kaplan (1 ex.), 3.iv.2011, D. Kestin (1 ex.); Ga'ash Pool Nature Reserve, 7.v.2015, L. Friedman, on Eleocharis palustris (12 exx.); Herzliyya, swamp, 32 $10.3^{\prime \prime}$ N $34^{\circ} 49.4^{\prime \prime}$ E, 27.vi.2008, A. Freidberg (3 exx.); Tel Aviv, 10.v.2013, A. Shlagman (1 ex.); Southern Coastal Plain: Miqwe Yisrael, 20.iii.1945, Bylinski-Salz (1 ex.); Holot Nizzanim Nature Reserve, Roberts' Pool, 10.iv.2018, L. Friedman \& N. Dorchin, on Eleocharis palustris (30 exx.); Judean Foothills: Shoham, 31.iii.2006, W. Kuslitzky (1 ex.); Park Canada [Deir-Ayoub], 
20.iii.1939, wheat plot, J. H. Brair (2 exx.); Northern Negev: Bitronot Ruhama, Nahal Hazav, $31^{\circ} 32^{\prime \prime} \mathrm{N}$ $34^{\circ} 42^{\prime \prime}$ E, 5.iv.2005, L. Friedman (1 ex.).

Distribution: Syria, Israel, Iraq, Saudi Arabia, Egypt $[45,64]$. In Israel occurs throughout the country, except the desert areas, in swamps and on the banks of springs and vernal ponds, corresponding to the distribution of the host plant (Figure 4f,h).

Biology: Semi-aquatic or riparian. Feeds exceptionally on Eleocharis palustris (L.) Roem. \& Schult. (Cyperaceae) (Figure 4h). There is a clear correspondence between the occurence of the plant and the adult weevils, although it is unclear whether the larvae also prefer E. palustris. First host record. Adults active in March-July, but they are commonly found on the host plant only in March-April, later they occur under stones or in soil, at least during the daytime, when numerous pairs are in copula.

Lixinae Schoenherr, 1823 [43]

This subfamily comprises approximately 1500 species in 90 genera, cosmopolitan, with major diversity in the Palaearctic and Afrotropical regions [134]. Around 100 species in Israel, mostly with no special hygrohillous affinities.

Lixini Schoenherr, 1823 [43]

Comprises 13 genera with 236 species in the Palaearctic region [45].

Lixus Fabricius, 1801 [135]

The genus comprises 175 species in the Palaearctic region [45]. Thirteen species are recorded for Israel [45], although there are at least ten additional species (Friedman, unpublished data). Mostly associated with Asteraceae, Amaranthaceae, Apiaceae, Brassicaceae, and Chenopodiaceae. Most of these occur in Mediterranean, steppe or desert habitats and are not associated with water.

Lixus (Eulixus) iridis Olivier, 1807 [136]

(Figures 12f,k and 15a)

Material Examined: 64 exx.

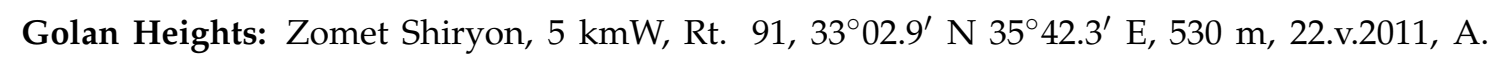
Freidberg (1 male); Nahal Qazrin, 4.v.1999, Y. Zamri (1 female), 25.v.2005, M. Cohen, O. Cohen, P. Yaniv (1 male); Susita, 15.iv.1982, Y. Nussbaum (1 male); Khispin, 28.x.1983, Y. Nussbaum (1 female); Hula Valley: Tel Dan [Tel el Kadi], 18.v.19??, H. Bytinski-Salz (1 female); Nahal Dan, 21.vii.1983, Y. Zvik (1 male); Nahal Hazbani, 23.v.1988, Y. Zvik (2 females); 'Amir, 8.iii.1946, H. Bytinski-Salz (1 male, 1 female); Hula, 23.vi.1952, J. Wahrman (1 female); Hula [Huleh], 1.v.1953, Kornhaus (1 female); Park haYarden, $32^{\circ} 54.5^{\prime} \mathrm{N} 35^{\circ} 37.5^{\prime} \mathrm{E},-210 \mathrm{~m}$, 14.iv.2011, E. Morgulis (1 female), 24.viii.2014, 18:00-21:00, L. Friedman (2 males, 4 females); Sea of Galilee Area: Gesher Arik, HaYarden, 17.viii.2014, L. Friedman (1 male); Nahal Samakh, 1.vii.1979 (1 female); Deganya A, 25.iii.1940, Y. Palmoni (1 female); Upper Galilee: Nahal Keziv, 12.v.1997, R. Hoffman (1 male, 1 female); Nahal ‘Ammud, 3.iii.1984, E. Shney-Dor (1 female); Mahanayyim, 6.x.1974, F. Kaplan (1 female); Lower Galilee: Nahal Keini, Megido, 30.iv.1993, Y. Zvik (2 males, 2 females); Nahal Tavor, 26.iii.2001, L. Friedman (1 male, 1 female); Carmel Ridge: 'En haShofet, 25.vi.2003, Y. Hershkovitz (1 male), A. Mozer (1 male); 'En haShofet, Irish Bridge, 16.vi.2004, A. Gasith, Y. Hershkovitz (1 male, 2 females), 16.vi.2004, A. Gasith (1 female); Central Coastal Plain: Binyamina [Benjamina], 16.iii.19??, H. Bytinski-Salz (1 male); Binyamina [Benjaminah], 6.iii.1924, on Asphodelus (1 male); Ahu Binyamina, 3.viii.1996, R. Hoffman (1 male); Nahal Barqan, 1.iii.1997, R. Hoffman (1 female); Hadera, 10.v.1939, Y. Palmoni (1 male); Berekhat Ramadan [Birquat Ramadan], 13.iii.1940, H. Bytinski-Salz (2 females); Tel Aviv, 12.viii.2003, N. Perlmutter (1 male); Samaria: Upper Nahal Tirza [Up. W. Faria], 28.iv.1976, M. Kaplan (1 female); Nahal Tirza [W. Faria], ii-iii.1973, D. Furth (1 male, 3 females), 2.iii.1973, D. Furth (1 male); Nahal Qana, 'Ein-el-Juze, 23.x.2016, L. Friedman, on Mentha longifolia (2 females); Judean Hills: ‘En Hemed [Aqua Bella], 29.iii.1954, J. Wahrman (1 male), 
24.iv.1961, J. Wahrman (1 female), 26.v.1961, Ritte (1 male); Yerushalayim [Jerusalem], 20.iv.1957, Ginsburg (1 male); Jordan Valley: Sede Eliyyahu, 6.iv.1961, D. Gerling, on plants (1 male); 'Enot Peza'el, -70 m, 23.v.2016, L. Friedman (1 male); Dead Sea Area: 'Ein Duyuq, 28.v.1971 (1 ex.), 7.v.1972 (1 ex.), 8.vi.1976 (1 female); Yeriho [Jericho], 18.iv.1982, Q. Argaman (1 female).

Distribution: West Palaearctic (Europe, North Africa, Caucasus, Middle East, Middle Asia) [45]. First record for Israel. In Israel found in humid biotopes: on the banks of streams, swamps, and ponds, in deep shady ravines. All specimens that I collected personally, or those whose collectors I was able to interview or to trace their collecting sites, which comprise the majority of the examined specimens, were collected on water plants above the water or as close as possible to the water.

Biology: Riparian. On Anthriscus silvestris L., Peucedanum palustre (L.) Moench, Angelica, Berula, Chaerophyllum, Cicuta, Conium, Heracleum, Levisticum, Oenanthe, Selinum, Sium, Pastinaca (Apiaceae) [137]. Larvae develop in stem [138,139]. In Israel the host remains unknown despite the relative commonness of the species. Adults are active in April-August.

\section{Discussion}

Israel is, on the one hand, a small country situated on the southern arid margin of the Palaearctic region; while on the other hand constituting a crossroads between Europe, Asia, and Africa [140]. This unique geographical position strongly affects its faunistic composition. Forty-one hygrophilous species are recorded here from Israel, including two fossil species. Among the extant 39 species, ten are aquatic, five are semi-aquatic, and 20 species are riparian. While three species, Bagous libanicus, B. septemcostatus and B. ruber, are geophilous, not necessarily associated either with water or wet habitats, they are also listed here as being part of the predominantly aquatic genus Bagous and as being active in wet soil in the winter only.

The extant hygrophilous weevil fauna of Israel (excluding the fossil species) is distinctly Palaearctic, comprising 36 Palaearctic, one Holarctic, one Afrotropical, and one introduced Nearctic species. Half of the Palaearctic species (16) have a fairly wide distribution throughout the Palaearctic region (three wide Palaearctic, six west Palaearctic and seven circum-Mediterranean), and half are restricted to the arid warm areas of the Mediterranean, Near East, and Middle Asia. Most of these species occur at the southernmost point of their distribution. The only Afrotropical species, Aorus anthracinus, is, in contrast, at its northernmost distributional point, and is probably a relic from the distant epoch when the Jordan Valley was still connected directly to the rest of the Rift Valley (its African part) by a chain of freshwater or brackish water bodies, presenting a vector of introduction of tropical species from sub-Saharan Africa, similar to the introduction of numerous plant and animal species into Israel $[10,14,16,140,141]$. The Nearctic Stenopelmus rufinasus appeared in 2010 in two completely different places in Israel. It is unclear whether this was a single invasional event or the species was established in Israel - no additional specimens have been collected since. Two species are probably endemic: Bagous lyali is an endemic of the Hula swamp and Echinocnemus sahlbergi is an endemic of the Central Coastal Plain. Both these endemic species are either extinct or very rare and have not been re-collected for many years. Bagous libanicus, described from a single specimen from Lebanon, is widely distributed throughout the less arid and more temperate parts of Israel, being to date an endemic of the Levant. I assume that it is widely distributed also in Syria and maybe also reaches Turkey, but this can only be proven following additional collecting efforts (sifting and collecting in pitfall traps).

Most Israeli hygrophilous weevils have a restricted distribution within the country, which is, of course, prescribed by their association with water sources. Many occur only in the humid upper Jordan Valley (Hula Valley (Figure 3a-d) and the Sea of Galilee Area) and/or in the Northern and Central Coastal Plain, where small areas of the primeval wetlands still exist. However, there are some species restricted to a single locality, such as Bagous bagdatensis, B. lyali, and Aorus anthracinus, known 
only from the Hula swamp; Bagous validus, restricted to the Berekhat Ya'ar winter pool (Figure 4a); and Icaris sparganii, which occurs only in the small $\left(38.5 \mathrm{~m}^{2}\right)$ Ga' ash winter pool (Figure $\left.4 \mathrm{f}\right)$.

The riparian weevil species in Israel can be roughly divided into those associated only with their riparian host plants (Nanophyiinae, Gymnetron spp., Tanymecus musculus); and those restricted to the riparian belt by the abiotic factors (humidity, temperature, etc.), while their host plants have a wider distribution (Squamapion delagrangei, Tychius spp., Lixus iridis, Sitona lividipes).

Most of the riparian species are common and appear in large numbers on their host plants, at least in some localities, whereas the aquatic and semi-aquatic weevils are comparatively rarely collected, usually as singletons or in short series. This does not necessarily mean, however, that they are rare. Many of these species are probably nocturnal, with diurnal collecting revealing individual specimens only. This is probably the case, for example, with Bagous bagdatensis and Rhinoncus pericarpius, collected several times in pitfalls, probably at night. B. validus and I. sparganii were predominantly collected in the evening. However, most of the localities in which aquatic weevils occur are nature reserves (e.g., Hula, Berekhat Ya'ar, Ga'ash, 'En Afeq), in which all activities are forbidden at night and I was therefore unable to validate my speculation. The collecting at night on the banks of the Jordan River near where it flows into the Sea of Galilee (Park haYarden) resulted in mass collecting of Rhinoncus perpendicularius, Squamapion delagrangei, Tychius bicolor, and T. meliloti, but no other hygrophilous weevils were found.

Compared to the Palaearctic fauna, the Israeli fauna is poor in aquatic species, which can be explained by the aridity of the climate. Many of the aquatic and semi-aquatic taxa widely distributed and common in the Palaearctic are lacking in Israel, e.g., erirhinin genera Grypus Germar, Notaris Germar, Tanysphyrus Germar, Thryogenes Bedel, Tournotaris Alonso-Zarazaga \& Lyal [7,45]. The conoderin tribe Phytobiini, richest in the hygrophilous taxa, commonly represented in the West Palaearctic by the genera Eubrychius C. G. Thomson, Neophytobius Wagner, Pelenomus C. G. Thomson, Phytobius Schoenherr, Rhinoncus Schoenherr, and Tapinotus Schoenherr [7,45], is represented in Israel solely by Rhinoncus, with two species, both quite restricted in their distribution. The predominantly aquatic species-rich genus Bagous with ca. 300 described species [2], is represented in Israel by ten species. This number is probably higher than might be expected in an arid country like Israel, but it is remarkable that, of these ten species, three are geophilous, not associated with wetlands, and two are semi-aquatic.

The degradation and loss of the wetland biotopes as a consequence of human activity distinctly threaten the hygrophilous weevils. Five of them have already reached the red line of endangerment: Aorus anthracinus, Arthrostenus fullo, and Echinocnemus reitteri; and the endemic Bagous lyali and Echinocnemus sahlbergi have become either extinct or extremely rare as a result of drainage of the Hula swamp and extermination of the wetland habitats throughout the Coastal Plain. Additional efforts are required to confirm their status. Because the Hula Nature Reserve, which includes the remnants of the Hula swamp, is overly protected, this makes insect collecting there very difficult. I nonetheless do not give up hope of re-discovering these species in the Hula, being inspired by the rediscovery of the Hula painted frog Latonia nigriventer (Mendelssohn and Steinitz) (Amphibia: Alytidae) endemic to the Hula Valley, which had not been collected since 1955, was declared as extinct in 1996, but was since occasionally re-discovered in 2011 [15,74].

Additional hygrophilous weevil species might also occur in Israel. The genus Echinocnemus has two additional representatives in Egypt [45,88], inhabiting biotopes resembling those of the Coastal Plain of Israel. Grypus equiseti Fabricius is a widely-distributed Palaearctic species, associated with Equisetum spp. (Pteridophyta: Equisetaceae). Two species of Equisetum occur in Israel: E. telmateia Ehrh. in the northern Hula Valley, on the banks of Nahal Senir, Nahal Dan, and Nahal Qoren (Figure 16a-c); and E. ramosissimum Desf. in the Hula Valley, Upper Galilee, Coastal Plain, and Samarian Hills (where it is severely grazed by goats and sheep), on the banks of the streams (Figure 16d,e). Numerous unidentified aquatic weevils were observed in Saluqiyya Springs ('Eden Springs) near Qazrin, Golan Heights, in May 2017 (Liron Goren, pers. comm.); unfortunately, I have been unable to date to check this interesting record. 

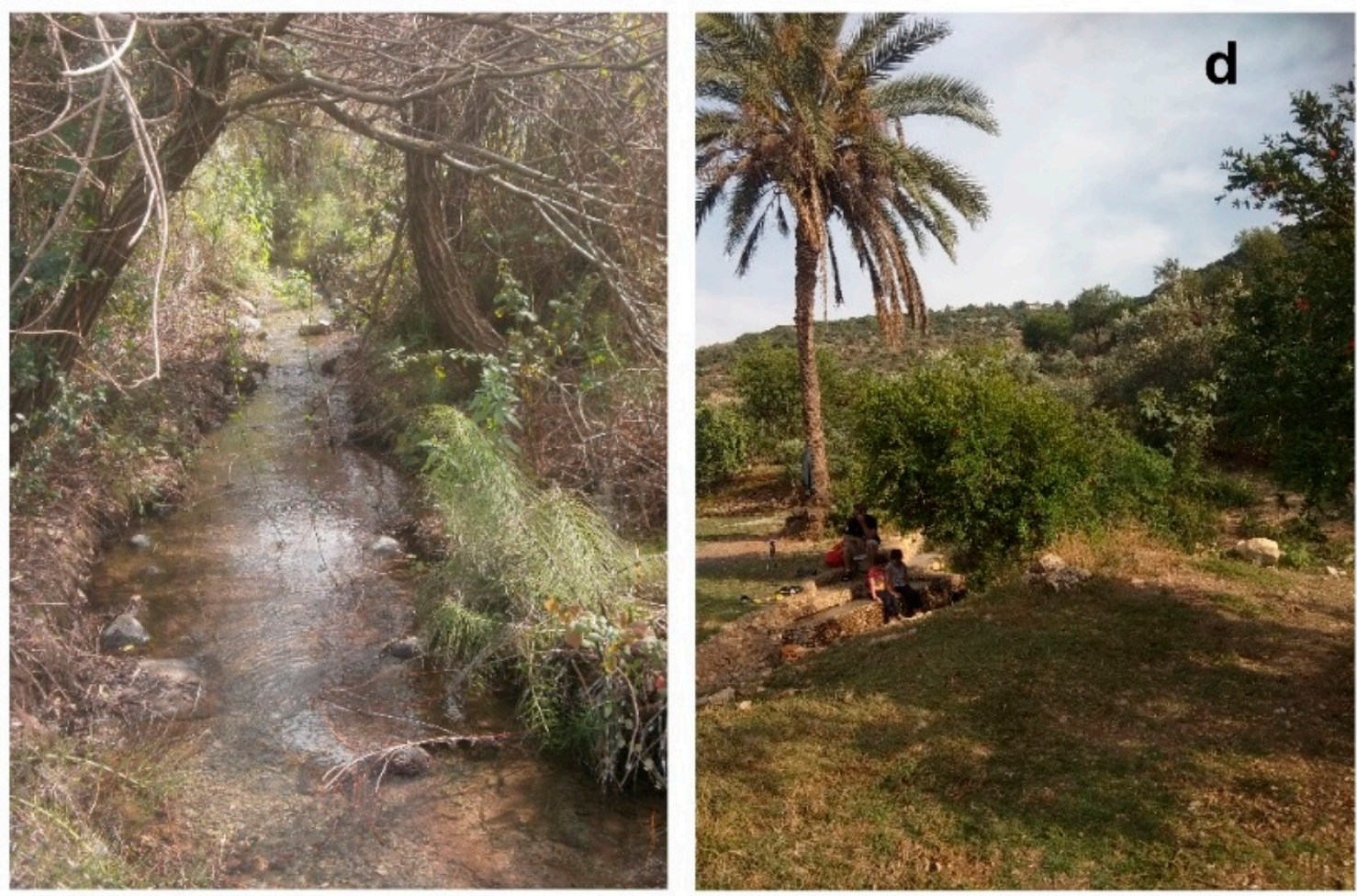

\section{a}

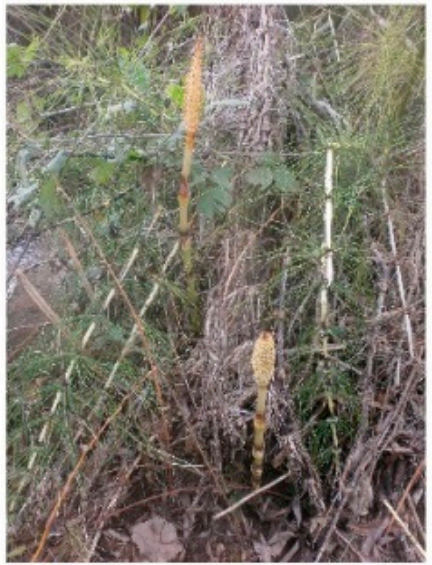

b

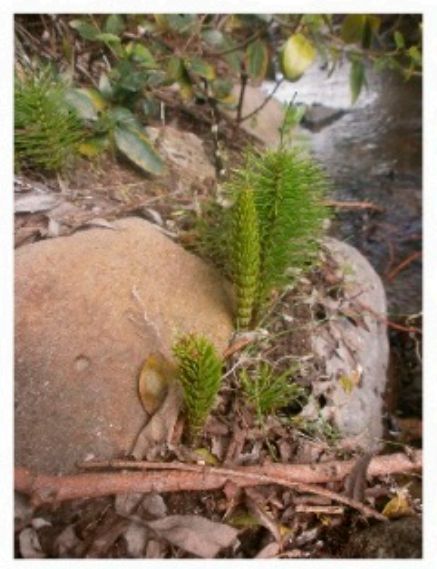

C

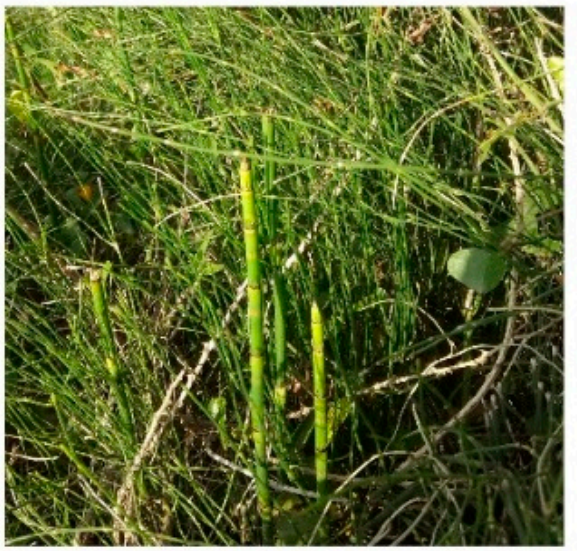

e

Figure 16. (a) Nahal Senir Nature Reserve, Equisetum telmateia on banks of Nahal Senir; (b,c) same place, Equisetum telmateia; (d) Nahal Qana, 'Ein-el-Basa, Equisetum ramosissimum growing in a thicket of Ephedra sp., Rubus sanctus and Smilax aspera; (e) same place, Equisetum ramosissimum. 


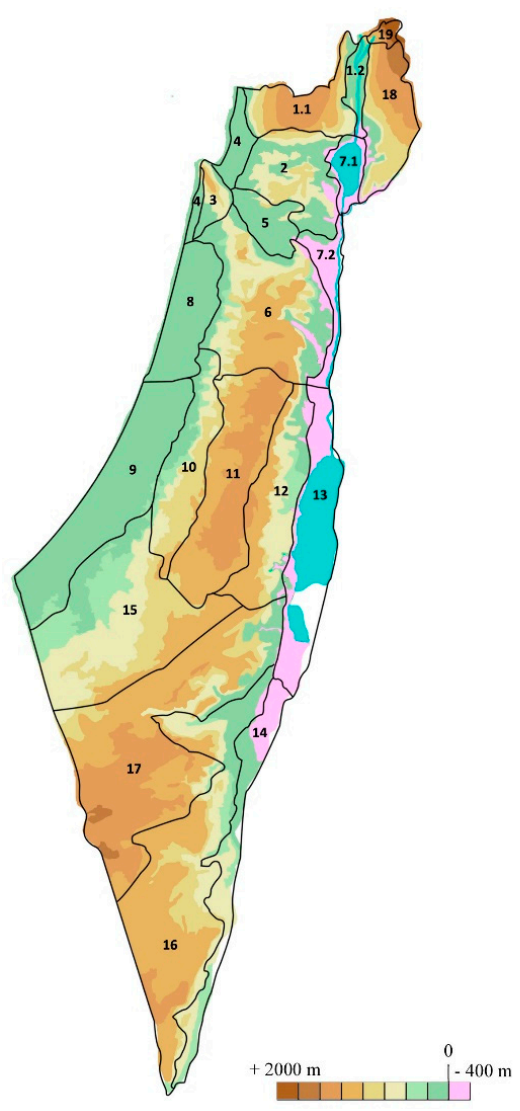

Figure 17. Zoogeographical map of Israel.

Names of the geographic regions of Israel (Figure 17).

1. Upper Galilee

1.1. Upper Galilee Hills

1.2. Hula Valley

2. Lower Galilee

3. Karmel (Carmel) Ridge

4. Northern Coastal Plain

5. Yizre'el (Jezreel) Valley

6. Shomeron (Samaria)

7. Jordan Valley \& Southern Golan

7.1. Sea of Galilee Area

7.2. Jordan Valley

8. Central Coastal Plain

9. Southern Coastal Plain

10. Judean Foothills

11. Judean Hills

12. Judean Desert

13. Dead Sea area

14. 'Arava Valley

15. Northern Negev

16. Southern Negev

17. Central Negev

18. Golan Heights

19. Mount Hermon 
Funding: This research received no external funding.

Acknowledgments: I cordially thank Netta Dorchin (SMNHTAU, Israel) for the administrative and financial support of my research. I thank Amnon Freidberg, Avital Gasith, Menahem Goren, Danny Simon, Vladimir Chikatunov, Vasiliy, Kravchenko, Yaron Hershkovitz, Liron Goren, David Furth, Ittai Renan, Michael Mostovski, Sergei Zonstein, Tania Novoselsky, Moshe Gershon, Armin Ionescu, and Tirza Stern (SMNHTAU, Israel), Amos Sabah, Yifat Artzi, Talya Oron, Ohad Mas, Yariv Malihi, Dana Milstein, Michael Blekher, Natan Banosevitch, Rami Yosefi, Moshe Mintz, Eldad Hazan, Erez Baruchi, Hagay Shlomo, and Margareta Walczak (Israel Nature Protection Authority), and Efi Naim (Agmon haHula, JNF), for miscellaneous help over the years; David Furth (SMNHTAU, Israel) and Zohar Yanai (School of Zoology, Tel Aviv University, Israel), and three anonymous reviewers for reviewing the early draft of the manuscript and for their essential comments on the manuscript; Naomi Paz (School of Zoology, Tel Aviv University, Israel), for editing the manuscript and working hard to improve my English; Avi Shmida (The Hebrew University of Jerusalem, Israel) and Yuval Sapir (Tel Aviv University, Israel), for identification and location of plants; Sharon Berkovitch and her late father Dov Berkovitch (Ma'agan Mikha'el, Israel), for allowing me to work in his private collection of insects; Amikam Shoob (School of Zoology, Tel Aviv University, Israel) and Noam Avitzel (Karkur, Israel), for the use of their photographs; Lourdes Chamorro, (USNM, Washington, USA) for taking pictures of the unique specimen of Bagous septemcostatus; Enzo Colonnelli (Rome, Italy), Roberto Caldara (Milano, Italy), Boris Korotyaev (ZIN, St. Petersburg, Russia), Roman Borovec (Czech University of Life Sciences Prague, Czech Republic and Jozef Cunev (Nitra, Slovakia) for their help in identification of specimens, sending literature, and sharing data; and Michael Balke (ZSMU, Nunich, Germany) for lending me important material. I am particularly grateful to Lev Karnibad (Munich, Germany) for the financial support of my collecting trips.

Conflicts of Interest: The author declares no conflicts of interest.

\section{References}

1. Oberprieler, R.G.; Marvaldi, A.E.; Anderson, R.S. Weevils, weevils, weevils everywhere. Zootaxa 2007, 1668, 491-520.

2. Caldara, R.; O'Brien, C.W.; Meregalli, M. A phylogenetic analysis of the aquatic weevil tribe Bagoini (Coleoptera: Curculionidae) based on morphological characters of adults. Zootaxa 2017, 4287, 1-63. [CrossRef]

3. Egorov, A.B.; Korotyaev, B.A. Review of the weevil tribe Emphyastini (Coleoptera, Curculionidae), habitants on supralittoral of the Sea of Japan, Ochotian and Behring seas. Proc. Zool. Inst. Acad. Sci. USSR 1976, 77, 43-55. (In Russian)

4. Friedman, A.L.L. Review of the biodiversity and zoogeographical patterns of the weevils (Coleoptera, Curculionoidea) in Israel. ZooKeys 2009, 31, 133-148. [CrossRef]

5. Kuschel, G. The foreign Curculionoidea established in New Zealand (Insecta: Coleoptera). N. Z. J. Sci. 1972, 15, 273-289.

6. Oevering, P.; Pitman, A.J. Characteristics of attack of coastal timbers by Pselactus spadix (Herbst) (Col.: Curc.: Cossoninae) and an investigation of its life history. Holzforschung 2002, 56, 335-359. [CrossRef]

7. Caldara, R.; O'Brien, C.W. Curculionidae: Aquatic weevils of China (Coleoptera). In Water Beetles of China; Jäch, M.A., Ji, L., Eds.; Zoologisch-Botanische Gesellschaft in Österreich and Wiener Coleopterologenverein: Wien, Austria, 1995; pp. 389-408.

8. Survey of Israel. Israel Touring Map (1:250,000) and List of Settlements (English Version); State of Israel, Ministry of Labor, 2 Sheets; Survey of Israel: Tel Aviv, Israel, 2009.

9. Israel Meterological Services, Ministry of Transport (IMS). 2018. Available online: http:/ /www.ims.gov.il/ IMS/CLIMATE/LongTermRain/ (accessed on 16 May 2018).

10. Goren, M.; Ortal, R. Biogeography, diversity and conservation of the inland water fish communities in Israel. Biol. Conserv. 1999, 89, 1-9. [CrossRef]

11. Por, D. An outline of the Zoogeography of the Levant. Zool. Scr. 1975, 4, 5-11. [CrossRef]

12. Shmida, A.; Aronson, J.A. Sudanian elements in the flora of Israel. Ann. Mo. Bot. Gard. 1986, 73, 1-28. [CrossRef]

13. Waisel, Y.; Liphschitz, N. Water Plants in Israel; Nature Conservation Authority: Tel Aviv, Israel, $1973 ;$ p. 82. (In Hebrew)

14. Waisel, Y.; Cohen, Y.; Pollak, G. Ecology of the Vegetation of Israel; Tel Aviv University. Sifriat Poalim: Tel Aviv, Israel, 1982; p. 462. (In Hebrew)

15. Biton, R.; Geffen, E.; Vences, M.; Cohen, O.; Bailon, S.; Rabinovich, R.; Malka, Y.; Oron, T.; Boistel, R.; Brumfeld, V.; et al. The rediscovered Hula painted frog is a living fossil. Nat. Commun. 2013, 4. [CrossRef] [PubMed] 
16. Dumont, H.J. Odonata of the Levant. Fauna Palaestina: Insecta V; The Israel Academy of Sciences and Humanities: Jerusalem, Israel, 1991; p. 300.

17. Furth, D.G. The Huleh and its lost aquatic leaf beetle. Atala 1976, 4, 4-9.

18. Dimentman, C.; Bromley, H.J.; Por, F.D. Lake Hula. Reconstruction of the Fauna and Hydrobiology of a Lost Lake; The Israel Academy of Sciences and Humanities: Jerusalem, Israel; Keter Press Enterprises: Jerusalem, Israel, 1992; p. 196.

19. Hambright, K.D.; Zohary, T. Lakes Hula and Agmon: Destruction and creation of wetland ecosystems in northern Israel. Wetl. Ecol. Manag. 1998, 6, 83-89. [CrossRef]

20. Karmon, Y.; Livne, M. The Hula Valley and its vicinity. Ariel 1990, 75-76, 1-192.

21. Freidberg, A. Life in the Dead Sea. Isr. J. Ent. 1981, 15, 101-102.

22. Ortal, R.; Gabai, S.; Frankenberg, E. National Report on the Implementation of the RAMSAR Convention on Wetlands. Israel. National Reports to Be Submitted to the 10th Meeting of the Conference of the Contracting Parties, Republic of Korea, 28 October-4 November 2008; p. 37. Available online: http: / / www.sviva.gov.il/InfoServices/ReservoirInfo/DocLib2/Publications/P0401-P0500/P0473.pdf (accessed on 20 May 2018).

23. Gasith, A. Conservation and management of the coastal streams of Israel: An assessment of stream status and prospect for rehabilitation. In River Conservation and Management; Boon, P.J., Calow, P., Petts, G.E., Eds.; John Wiley \& Sons Ltd.: New York, NY, USA, 1992; pp. 51-63.

24. Levin, N.; Lahav, H.; Ramon, U.; Heller, A.; Nizry, G.; Tsoar, A. Landscape continuity analysis: A new approach to conservation planning in Israel. Landsc. Urban Plan. 2007, 79, 53-64. [CrossRef]

25. Levin, N.; Elron, E.; Gasith, A. Decline of wetland ecosystems in the coastal plain of Israel during the 20th century: Implications for wetland conservation and management. Landsc. Urban Plan. 2009, 92, 220-232. [CrossRef]

26. Furth, D.G. Aquatic entomofauna of a Dead Sea oasis. Hydrobiologia 1983, 102, 3-25. [CrossRef]

27. Botosaneanu, L.; Gasith, A. Contributions taxonomiques et ecologiques a la connaissance des trichopteres (Insecta) d'Israel. Isr. J. Zool. 1971, 20, 89-129.

28. Bromley, H.J. A note on the Plecoptera of Israel. Isr. J. Ent. 1988, 22, 1-12.

29. Demoulin, G. Contribution à l'étude des Ephéméroptères d'Israel. Introduction et I. Heptageniidae. Bull. Inst. R. Sci. Nat. Belg. 1973, 49, 1-19.

30. Lyal, C.H.C. 3.7.7. Molytinae Schoenherr, 1823. pp. 529-570. In Handbook of Zoology. Arthropoda: Insecta; Coleoptera, Beetles. Vol. 3. Morphology and Systematics (Phytophaga); Leschen, R.A.B., Beutel, R.G., Kristensen, N.P., Beutel, R.G., Eds.; Walter de Gruyter: Berlin, Germany; Boston, MA, USA, 2014; Volume 3 , p. 675.

31. Sartori, M. Mayflies from Israel (Insecta; Ephemeroptera) I. Heptageniidae, Ephemerellidae, Leptophlebiidae \& Palingeniidae. Rev. Suisse Zool. 1992, 99, 835-858.

32. Hebauer, F. The Hydrophiloidea of Israel and the Sinai (Coleoptera, Hydrophiloidea). Zool. Middle East 1994, 10, 73-137. [CrossRef]

33. Jäch, M.A.; Ortal, R. The large water beetles of Israel-On the verge of extinction. Soc. Prot. Nat. (Israel) 1988, 6, 37-49.

34. Wewalka, G. Die Arten der Gattung Scarodytes aus Griechenland und eine neue Art dieser Gattung aus Israel (Dytiscidae, Col.). Kol. Rundsch. 1977, 53, 137-144.

35. Wewalka, G. Systematic and faunistic notes on Noteridae and Dytiscidae of the Near East (Coleoptera). Kol. Rundsch. 1989, 59, 143-152.

36. Caldara, R.; O'Brien, C.W. Systematics and evolution of Weevils of the genus Bagous. VI. Taxonomic treatment of the species of the Western Palearctic Region (Col. Curculionidae). Mem. Soc. Ent. It. 1998, 76, 131-347.

37. Alonso-Zarazaga, M.A.; Lyal, C.H.C. A World Catalogue of Families and Genera of Curculionoidea (Insecta: Coleoptera) (Excepting Scolytidae and Platypodidae); Entomopraxis, S.C.P.: Barcelona, Spain, 1999; p. 315.

38. Danin, A.; Fragman-Sapir, O. Flora of Israel Online. 2017. Available online: http://flora.org.il/en/plants (accessed on 12 June 2018).

39. Theodor, O. Diptera Pupipara. Fauna Palaestina. Insecta I; The Israel Academy of Sciences and Humanities: Jerusalem, Israel, 1975; p. 170. 
40. Ionescu, A.; Eyer, P.-A. Notes on Cataglyphis Foerster, 1850 of the bicolor species-group in Israel, with description of a new species (Hymenoptera: Formicidae). Isr. J. Ent. 2016, 46, 109-131.

41. Caldara, R. Curculionidae: Bagoinae, pp. 172-176. In Catalogue of Palaearctic Coleoptera; Löbl, I., Smetana, A., Eds.; Brill: Leiden, The Netherlands, 2013; Volume 8, p. 700.

42. Billberg, G.J. Enumeratio Insectorum in Museo Gust. Joh. Billberg; Typis Gadelianis: Stockholm, Sweden, 1820; p. 138.

43. Schoenherr, C.J. Curculionides. [Tabula synoptica familiae Curculionidum]. Isis Oken 1823, 13, 1132-1146.

44. Alonso-Zarazaga, M.A.; Wanat, M. 3.6.3. Apioninae Schoenherr, 1823. pp. 395-415. In Handbook of Zoology. Arthropoda: Insecta; Coleoptera, Beetles. Vol. 3. Morphology and Systematics (Phytophaga); Leschen, R.A.B., Beutel, R.G., Kristensen, N.P., Beutel, R.G., Eds.; Walter de Gruyter: Berlin, Germany; Boston, MA, USA, 2014; p. 675.

45. Alonso-Zarazaga, M.A.; Barrios, H.; Borovec, R.; Bouchard, P.; Caldara, R.; Colonnelli, E.; Gültekin, L.; Hlaváč, P.; Korotyaev, B.; Lyal, C.H.C.; et al. Cooperative catalogue of Palaearctic Coleoptera Curculionoidea. Monogr. Electrón. Soc. Entomol. Aragon. 2017, 8, 1-729.

46. Friedman, A.L.L.; Freidberg, A. The Apionidae of Israel and the Sinai Peninsula (Coleoptera: Curculionoidea). Isr. J. Ent. 2007, 37, 55-180.

47. Wencker, J.A. Apionides, tribu des curculionides. L'Abeille 1864, 1, 109-270.

48. Desbrochers des Loges, J. Espèces inédites de curculionides de l'Ancien-Monde IV. [Cont.]. Le Frelon 1895, 4, $81-96$.

49. Gistel, J.N.F.X. Naturgeschichte des Thierreichs. Für Höhere Schulen Bearbeitet Durch Johannes Gistel. Mit Einem Atlas von 32 Tafeln (Darstellend 617 illuminirte Figuren) und Mehreren dem Texte Eingedruckten Xylographien; Hoffmann'sche Verlags-Buchhandlung: Stuttgart, Germany, 1848; p. 216.

50. Alonso-Zarazaga, M.A. Revision of the supraspecific taxa in the Palaearctic Apionidae Schoenherr, 1823 (1. Introduction and subfamily Nanophyinae. Fragm. Ent. Roma 1989, 21, 205-262.

51. Alonso-Zarazaga, M.A. 3.6.4. Nanophyinae Gistel, 1848. pp. 416-423. In Handbook of Zoology. Arthropoda: Insecta; Coleoptera, Beetles. Vol. 3. Morphology and Systematics (Phytophaga); Leschen, R.A.B., Beutel, R.G., Kristensen, N.P., Beutel, R.G., Eds.; Walter de Gruyter: Berlin, Germany; Boston, MA, USA, 2014; p. 675.

52. Des Gozis, M. Notes et remarques pour le futur catalogue de la faune gallo-rhénane (2e série). Rev. Ent. 1885, 4, 116-132.

53. Reitter, E. Fauna Germanica. In Die Käfer des Deutsches Reiches. Nach der Analytische Methode Bearbeitet; V. Band; K. G. Lutz: Stuttgart, Germany, 1916; p. 343.

54. Costa, A. Nuovi studii sulla entomologia della Calabria Ulteriore. Atti Della Accad. Sci. Fis. Nat. Napoli 1863, 1, 1-80.

55. Tournier, H. De quelques nouveaux coléoptères d'Europe et d'Algérie. Ann. Soc. Ent. Fr. 1868, 7, 561-570.

56. Giordani-Soika, A. Risultati scientifici delle spedizioni entomologiche di S.A.S. il Principe Alessandro della Torre e Tasso nel Bacino del Mediterraneo. I. Le specie mediterranee del genere Corimalia (Col. Curc.). Publ. Mus. Ent. Pietro Rossi 1937, 2, 1-29.

57. Pic, M. Coléoptères nouveaux. Misc. Ent. 1897, 5, 26-29.

58. Boheman, C.H. [new taxa]. In Genera et Species Curculionidum, cum Synonymia Hujus Familiae. Species Novae aut Hactenus Minus Cognitae, Descriptionibus a Dom. L. Gyllenhal, C. H. Boheman, O. J. Fahraeus et Entomologis Aliis Illustratae; Tomus octavus.-Pars secunda. Supplementum Continens; Parisiis: Roret; Schoenherr, C.J., Ed.; Flescher: Lipsiae, Germany, 1845; pp. 1-504.

59. Gyllenhal, L. [new taxa]. In Genera et Species Curculionidum, cum Synonymia Hujus Familiae. Species Novae aut Hactenus Minus Cognitae, Descriptionibus a Dom. Leonardo Gyllenhal, C. H. Boheman, et Entomologis Aliis Illustratae; Tomus quartus.-Pars secunda; Parisiis: Roret; Schoenherr, C.J., Ed.; Flescher: Lipsiae, Germany, 1838; pp. 601-1124.

60. Latreille, P.A. Histoire Naturelle, Générale et Particulière, des Crustacés et des Insectes. Ouvrage Faisant Suite aux Oeuvres de Leclerc de Buffon, et Partie du Cours Complet D’histoire Naturelle Rédigé Par C. S. Sonnini, Membre de Plusieurs Sociétés Savantes; Tome troisième; F. Dufart: Paris, France, 1802; p. 467.

61. Thomson, C.G. Skandinaviens Coleoptera, Synoptiskt Bearbetade; Berlingska Bocktryckeriet: Lund, Sweden, $1859 ;$ p. 290. 
62. Caldara, R.; Franz, N.M.; Oberprieler, R.G. 3.7.10. Curculioninae Laterille, 1802. pp. 589-628. In Handbook of Zoology. Arthropoda: Insecta; Coleoptera, Beetles. Vol. 3. Morphology and Systematics (Phytophaga); Leschen, R.A.B., Beutel, R.G., Kristensen, N.P., Beutel, R.G., Eds.; Walter de Gruyter: Berlin, Germany; Boston, MA, USA, 2014; p. 675.

63. Sprick, P. Suitability of an insect group for the Habitats Directive of the EU: The weevil subfamily Bagoinae (Col., Curculionidae). Contributions to the Ecology of Phytophagous Beetles VII. Snudebiller 2001, 2, 7-40.

64. Bodenheimer, F.S. Prodromus Faunae Palestinae. Essai sur les élements zoogéographiques et historiques du sud-ouest du sous-régne paléarctique. Mém. Inst. Egypte 1937, 33, 1-286.

65. Germar, E.F. Miscellen und Correspondenz-Nachrichten. Mag. Ent. 1817, 2, 339-341.

66. Dejean, P.F.M.A. Catalogue de la Collection de Coléoptères de M. le Baron Dejean; Crevot: Paris, France, 1821.

67. Schilsky, J. Die Käfer Europa's. Nach der Natur beschrieben von Dr. H.C. Kuster und Dr. G. Kraatz. Heft 44; Bauer und Raspe (E. Küster): Nürnberg, Germany, 1907; p. 100.

68. Pic, M. Descriptions d'un Bryaxis et de plusieurs malacodermes ou rhyncophores. L'Échange Rev. Linn. 1904, 20, 49-51.

69. Gyllenhal, L. [new taxa]. In Genera et Species Curculionidum, Cum Synonymia Hujus Familiae. Species Novae Aut Hactenus Minus Cognitae, Descriptionibus a Dom. Leonardo Gyllenhal, C. H. Boheman, et Entomologis Aliis Illustratae; Tomus tertius.-Pars secunda; Parisiis: Roret; Schönherr, C.J., Ed.; Flescher: Lipsiae, Germany, 1836; pp. 506-858.

70. Dieckmann, L. Beiträge zur Insektenfauna der DDR: Coleoptera-Curculionidae (Tanymecinae, Leptopiinae, Cleoninae, Tanyrhynchinae, Cosonina, Raymondionyminae, Bagoinae, Tanysphyrinae). Beitr. Entomol. 1983, 33, 257-381.

71. Cunev, J. Nové a zaujívané nálezy chrobákov (Coleoptera) nadčel’ade Curculionoidea na území Slovenska. Entomofauna Carpathica 2013, 25, 1-14.

72. Blecher, M.; Blecher, I. Changes in vegetation in Nahal Boqeq: Is it due to the aqua pollution? Ecol. Vesviva 2011, 4, 255-256. (In Hebrew)

73. Fåhraeus, O.I. [new taxa]. In Genera et Species Curculionidum, Cum Synonymia Hujus Familiae. Species Novae Aut Hactenus Minus Cognitae, Descriptionibus a Dom. Leonardo Gyllenhal, C. H. Boheman, O. J. Fåhraeus, et Entomologis Aliis Illustratae; Tomus octavus._Pars secunda. Supplementum Continens; Parisiis: Roret; Schoenherr, C.J., Ed.; Flescher: Lipsiae, Germany, 1845; p. 504.

74. Bina Perl, R.G.; Gafny, S.; Malka, Y.; Renan, S.; Woodhams, D.C.; Rollins-Smith, L.; Pask, J.D.; Bletz, M.C.; Geffen, E.; Vences, M. Natural history and conservation of the rediscovered Hula painted frog, Latonia nigriventer. Cont. Zool. 2017, 86, 11-37.

75. Tournier, H. Matériaux pour servir à la monographie de la tribe des Erirrhinides de la familie des Curculionides (Coléoptères). Ann. Soc. Ent. Belg. 1874, 17, 63-116.

76. Chevrolat, L.A.A. Description de coléoptères nouveaux d'Algérie. Rev. Mag. Zool. Pure Appl. 1860, 12, 509-511.

77. Roesler, U. In Memoriam Dozent Dr. Stanislaw Blezsynski. Ent. Nachr. 1971, 18, 33-36.

78. Reitter, E. Neue Coleopteren aus Europa, den angrenzenden Ländern und Sibirien, mit Bemerkungen über bekannte Arten. Neunter Teil. Deutsch. Ent. Zeit. 1890, 10, 145-164.

79. Herbst, J.F.W. Natursystem Aller Bekannten in- und Ausländischen Insekten, Als Eine Fortsetzung der von Büffonschen Naturgeschichte; Der Käfer Sechster Theil; Joachim Pauli: Berlin, Germany, 1795; p. 520.

80. Rosenhauer, W.G. Beiträge zur Insekten-Fauna Europas, Erstes Bändchen; Enthält die Beschreibung von Sechzig Neuen Käfern aus Bayern, Tyrol, Ungarn, etc., Sowie die Käfer Tyrols, Nach Dem Ergebnisse von Vier Reisen Zusammengestellt; Theodor Blaesing: Erlangen, Germany, 1847; p. 159.

81. Schilsky, J. Die Käfer Europa's. Nach der Natur Beschrieben von Dr. H.C. Küster und Dr. G. Kraatz. Heft 47; Bauer und Raspe (E. Küster): Nürnberg, Germany, 1911; p. 100.

82. Schoenherr, C.J. Continuatio tabulae synopticae familiae curculionidum. Isis Oken 1825, 5, 581-588.

83. Schoenherr, C.J. Genera et Species Curculionidum, Cum Synonymia Hujus Familiae. Species Novae aut Hactenus Minus Cognitae, Descriptionibus a Dom. L. Gyllenhal, C. H. Boheman, O. J. Fåhraeus et Entomologis Aliis Illustratae; Tomus septimus. Pars secunda. Supplementum Continens; Parisiis: Roret; Flescher: Lipsiae, Germany, 1843; p. 461.

84. Caldara, R. A taxonomic revision of the weevil genus Picia Tournier, 1895 (Coleoptera: Curculionoidea: Erirhinidae). Zootaxa 2008, 1959, 39-57. 
85. Grachev, V.G. Family Curculionidae Latreille, 1802. pp. 196-198. In Plant-Arthropod Interactions in the Early Angiosperm History: Evidence from the Cretaceous of Israel; Part II. Fossil Insects in the Cretaceous Mangrove Facies of Southern Negev, Israel; pp. 189-224; Anisyutkin, L.N., Grachev, V.G., Ponomarenko, A.G., Rasnitsyn, A.P., Vršanský, P., Krassilov, V., Rasnitsyn, A., Eds.; Pensoft Publishers: Sofia, Bulgaria; Brill: Leiden, The Netherlands, 2008; p. 229.

86. Krassilov, V.; Silantieva, N.; Lewy, Z. Part I. Traumas on Fossil Leaves from the Cretaceous of Israel, pp. 1-187. In Plant-Arthropod Interactions in the Early Angiosperm History: Evidence from the Cretaceous of Israel; Krassilov, V., Rasnitsyn, A., Eds.; Pensoft Publishers: Sofia, Bulgaria; Brill: Leiden, The Netherlands, 2008.

87. Rabinovich, R.; Hanan, H.; Schudack, M.; Schudack, U.; Ashckenazi-Polivoda, S.; Rogolsky, G. A late Cretaceous elasmosaurid of the Tethys Sea margins (southern Negev, Israel), and its palaeogeographic reconstruction. Neth. J. Geosci. 2015, 94, 73-86.

88. Alfieri, A. The Coleoptera of Egypt. Mém. Soc. Ent. Egypte 1976, 5, 1-362.

89. Korotyaev, B.A. Family Curculionidae. pp. 145-149. In Key to Harmful and Useful Insects and Mites on Grain Plants in the USSR; Kopaneva, L.M., Ed.; Kolos: Leningrad, Russia, 1980. (In Russian)

90. Marshall, G.A.K. On the West African species of Echinocnemus Schoen. (Col., Curculionidae). Ann. Mag. Nat. Hist. 1950, 3, 765-774. [CrossRef]

91. Oberprieler, R. 3.7.1. Brachycerinae Billberg, 1820. pp. 424-451. In Handbook of Zoology. Arthropoda: Insecta; Coleoptera, Beetles. Vol. 3. Morphology and Systematics (Phytophaga); Leschen, R.A.B., Beutel, R.G., Kristensen, N.P., Beutel, R.G., Eds.; Walter de Gruyter: Berlin, Germany; Boston, MA, USA, 2014.

92. Singh, J.; Dhaliwal, G.S. Rice root weevil problem in India-An overview. Ind. J. Ent. 1990, 52, $217-222$.

93. Sahlberg, J.R. Coleoptera mediterranea orientalia, quae in Aegypto, Palaestina, Syria, Caramania atque in Anatolia occidentali anno 1904 collegerunt John Sahlberg et Unio Saalas. Öfversigt Fin. Vetensk-Soc. Förhandlingar (A) 1913, 55, 1-281.

94. Schilsky, J. Die Käfer Europa's. Nach der Natur Beschrieben von Dr. H.C. Kuster und Dr. G. Kraatz. Heft 44; Bauer und Raspe (E. Küster): Nürnberg, Germany, 1907; p. 100.

95. Gyllenhal, L. [new taxa]. In Genera et Species Curculionidum, Cum Synonymia Hujus Familiae. Species Novae Aut Hactenus Minus Cognitae, Descriptionibus a Dom. Leonardo Gyllenhal, C. H. Boheman, et Entomologis Aliis Illustratae; Tomus tertius-Pars prima. [1836]; Parisiis: Roret; Schoenherr, C.J., Ed.; Flescher: Lipsiae, Germany, 1835; p. 505.

96. Miller, L. Neue Käfer aus Kindermann's Vorräthen. Wien. Ent. Monatsch. 1861, 5, 201-209.

97. Caldara, R. Curculionidae: Curculioninae, pp. 117-172. In Catalogue of Palaearctic Coleoptera; Löbl, I., Smetana, A., Eds.; Brill: Leiden, The Netherlands, 2013; Volume 8, p. 700.

98. Zumpt, F. Revision der Genera Notaris Germ., Lepidonotaris m., Thryogenes Bed., Grypus Germ., Icaris Tourn. und Picianus m. (Col. Curc.). Col. Cent. 1929, 3, 213-239.

99. Faust, J. Die europäischen und asiatischen Arten der Gattungen Erirhinus, Notaris, Icaris, Dorytomus. Bull. Soc. Impériale Nat. Moscou 1882, 57, 113-188.

100. Benedikt, S.; Borovec, R.; Fremuth, J.; Kratky, J.; Schoen, K.; Skuhrovec, J.; Tryzna, M. Annotated checklist of weevils (Coleoptera: Curculionoidea excepting Scolytinae and Platypodinae) of the Czech Republic and Slovakia. Klapalekiana 2010, 46, 1-363.

101. Dieckmann, L. Beiträge zur Insektenfauna der DDR: Coleoptera-Curculionidae (Erirhinae). Beitr. Entomol. 1986, 36, 119-181.

102. Tournier, H. [Rectification]. Bull. Soc. Ent. Fr. 1895, 63.

103. David'yan, G.E. Interactive Agricultural Ecological Atlas of Russia and Neighboring Countries. Economic Plants and their Diseases, Pests and Weeds. Hydronomus sinuaticollis Faust-Rice Water Weevil. 2009. Available online: http://www.agroatlas.ru/en/content/pests/Hydronomus_sinuaticollis/index.html (accessed on 11 June 2018).

104. Reitter, E. Coleopterologische Ergebnisse der im Jahre 1886 und 1887 in Transcaspien von Dr. G. Radde, Dr. A. Walter und A. Konchin ausgeführten Expedition. Verh. Naturforschenden Vereines Brünn 1889, 27, 95-133.

105. Schoenherr, C.J. Curculionidum Dispositio Methodica Cum Generum Characteribus, Descriptionibus Atque Observationibus Variis, Seu Prodromus ad Synonymiae Insectorum, Partem IV; Fridericum Fleischer: Lipsiae, Germany, 1826; p. 338.

106. Isaev, A.Y. Opredelitel Zhukov Srednego Povolzhia. Part 3. Polyphaga-Phytophaga; Vector-S: Ulyanovsk, Russia, 2007; p. 256. (In Russian) 
107. Boheman, C.H. [new taxa]. In Genera et Species Curculionidum, Cum Synonymia Hujus Familiae. Species Novae Aut Hactenus Minus Cognitae, Descriptionibus a Dom. Leonardo Gyllenhal, C. H. Boheman, et Entomologis Aliis Illustratae; Tomus tertius._-Pars secunda; Parisiis: Roret; Schoenherr, C.J., Ed.; Flescher: Lipsiae, Germany, 1836; Volume 4, 505p.

108. Schoenherr, C.J. Genera et Species Curculionidum, Cum Synonymia Hujus Familiae. Species Novae Aut Hactenus Minus Cognitae, Descriptionibus a Dom. Leonardo Gyllenhal, C. H. Boheman et Entomologis Aliis Illustratae; Tomus tertius. Pars prima [1836]; Parisiis: Roret; Flescher: Lipsiae, Germany, 1835; p. 505.

109. Caldara, R. Erirhinidae. In Catalogue of Palaearctic Coleoptera; Löbl, I., Smetana, A., Eds.; Apollo Books: Stenstrup, Denmark, 2011; Volume 7, pp. 192-198.

110. Friedman, A.L.L. The first record of the Azolla frond weevil Stenopelmus rufinasus (Curculionidae: Brachycerinae: Tanysphyrini) in Israel. Isr. J. Ent. 2017, 47, 103-106.

111. Hill, M.P.; McConnachie, A.J. Azolla filiculoides Lamarck (Azollaceae). In Biological Control of Tropical Weeds Using Arthropods; Muniappan, R., Reddy, G.V.P., Raman, A., Eds.; Cambridge University Press: Cambridge, UK, 2009; pp. 74-87.

112. Dufour-Dror, J.-M. Invasive Aquatic Plants. Kalanit. 2014. Available online: http://www.kalanit.org.il/ ?p= 279 (accessed on 15 October 2017). (In Hebrew)

113. Lacordaire, J.T. Histoire Naturelle des Insectes. Genera des Coléoptères ou Exposé Méthodique et Critique de tous les Genres Proposés Jusqu'ici Dans cet Ordre D'insectes; Tome Sixième; Roret: Paris, France, 1863; p. 637.

114. Marshall, G.A.K. On the genus Aorus, Schh. (Coleoptera, Curculionidæ). Ann. Mag. Nat. Hist. 1919, 4, $338-343$. [CrossRef]

115. Brancsik, K. Coleoptera africana nova. Trencsén Természettud. Egylet Évkönyve 1989, 19-20, 108-131.

116. Schoenherr, C.J. Genera et Species Curculionidum, Cum Synonymia Hujus Familiae. Species Novae Aut Hactenus Minus Cognitae, Descriptionibus a Dom. Leonardo Gyllenhal, C. H. Boheman et Entomologis Aliis Illustratae; Tomus primus._Pars prima; Parisiis: Roret, Kenya, 1833; p. 381.

117. Prena, J.; Colonnelli, E.; Hespenheid, H.A. 3.7.9. Conoderinae Schoenherr, 1823. pp. 577-589. In Handbook of Zoology. Arthropoda: Insecta; Coleoptera, Beetles. Vol. 3. Morphology and Systematics (Phytophaga); Leschen, R.A.B., Beutel, R.G., Kristensen, N.P., Beutel, R.G., Eds.; Walter de Gruyter: Berlin, Germany; Boston, MA, USA, 2014; p. 675.

118. Colonnelli, E. Catalogue of Ceutorhynchinae of the World, with a Key to Genera (Insecta: Coleoptera: Curculionidae); Argania Edito: Barcelona, Spain, 2004; p. 124.

119. Korotyaev, B.A. A review of the weevil genus Rhinoncomimus Wagner (Coleoptera: Curculionidae: Ceutorhynchinae). Ent. Abh. 2006, 63, 99-122.

120. Rheinheimer, J.; Hassler, M. Die Rüsselkäfer Baden-Württembergs; Verlag Regionalkultur: Ubstadt-Weiher, Germany, 2010; p. 944.

121. Colonnelli, E. Checklist of Phytobiini of the world, with a key to the genera and description of a new species from South Africa (Coleoptera, Curculionidae, Ceutorhynchinae). Fragm. Ent. 1986, 19, 155-168.

122. Linnaeus, C. Systema Naturae per Regna Tria Naturae, Secundum Classes, Ordines, Genera, Species, Cum Caracteribus, Differentiis, Synonymis; Laurentii Salvii: Holmiae, Sweden, 1758; p. 824.

123. Reich, G.C. Mantissae Insectorum Iconibus Illustratae Species Novas Aut Nondum Depictas Exhibentis; Felsecker: Norimbergae, Germany, 1797; p. 16.

124. Kirsch, T.F.W. Neue oder seltene Rüsselkäfer-Arten aus dem Gebiete des Mittelmeerbeckens. Ent. Monatsbl. 1881, 2, 3-16. [CrossRef]

125. Caldara, R. Revisione delle specie paleartiche del genere Gymnetron (Insecta, Coleoptera: Curculionidae). Aldrovandia 2008, 4, 27-104.

126. Desbrochers des Loges, J. Espèces inédites de curculionides de l'Ancien Monde. VI. Le Frelon 1900, 8, 1-16.

127. Brisout de Barneville, C.N.F. Méthode dichotomique appliquée aux Tychius de France et description de quelques espèces nouvelles des genres Tychius et Miccotrogus. Ann. Soc. Ent. Fr. 1863, 2, 756-780.

128. Caldara, R. Revisione tassonomica delle specie paleartiche del genere Tychius Germar (Coleoptera Curculionidae). Mem. Soc. Ital. Sci. Nat. Mus. Civ. Stor. Nat. Milano 1990, 25, 51-218.

129. Stephens, J.F. Illustrations of British Entomology; or, a Synopsis of Indigenous Insects: Containing Their Generic and Specific Distinctions; with an Account of Their Metamorphoses, Times of Appearance, Localities, Food, and Economy, as Far as Practicable. Mandibulata; Baldwin, Cradock: London, UK, 1831; p. 413. 
130. Marvaldi, A.E.; Lanteri, A.A.; Guadalupe del Rio, M.; Oberprieler, R.G. 3.7.5. Entiminae Schoenherr, 1823. pp. 529-570. In Handbook of Zoology. Arthropoda: Insecta; Coleoptera, Beetles. Vol. 3. Morphology and Systematics (Phytophaga); Leschen, R.A.B., Beutel, R.G., Kristensen, N.P., Beutel, R.G., Eds.; Walter de Gruyter: Berlin, Germany; Boston, MA, USA, 2014.

131. Velázquez de Castro, A.J.; Alonso Zarazaga, M.A.; Outerelo, R. Systematics of Sitonini (Col.: Curculionidae: Entiminae) with a hypothesis on evolution of feeding habits. Syst. Ent. 2007, 32, 212-331. [CrossRef]

132. Velázquez de Castro, A.J.; Friedman, A.L.L.; Borovec, R. Sitonini (Curculionidae: Entiminae) of Israel. Isr. J. Ent. 2010, 40, 71-108.

133. Fåhraeus, O.I. [new taxa]. In Genera et Species Curculionidum, Cum Synonymia Hujus Familiae; Species Novae Aut Hactenus Minus Cognitae, Descriptionibus a Dom. L. Gyllenhal, C. H. Boheman, O. J. Fåhraeus et Entomologis Aliis Illustratae; Tomus sextus. Pars prima; Parisiis: Roret; Schoenherr, C.J., Ed.; Flescher: Lipsiae, Germany, 1840; p. 474.

134. Meregalli, M. 3.7.6. Lixinae Schoenherr, 1823. pp. 523-529. In Handbook of Zoology. Arthropoda: Insecta; Coleoptera, Beetles. Vol. 3. Morphology and Systematics (Phytophaga); Leschen, R.A.B., Beutel, R.G., Kristensen, N.P., Beutel, R.G., Eds.; Walter de Gruyter: Berlin, Germany; Boston, MA, USA, 2014.

135. Fabricius, J.C. Systema Eleutheratorum Secundum Ordines, Genera, Species: Adiectis Synonimis, Locis, Observationibus, Descriptionibus; Impensis Bibliopolii Academici Novi: Kiel, Germany, 1801; p. 687.

136. Olivier, A.G. Entomologie, ou Histoire Naturelle des Insectes, Avec Leurs Caractères Génériques et Spécifiques, Leur Description, Leur Synonymie, et Leur Figure Enluminée. Coléoptères; Tome cinquième; Desray: Paris, France, 1807; p. 612.

137. Scherf, H. Die Entwicklungsstadien der mitteleuropäischen Curculioniden (Morphologie, Bionomie, Ökologie) [Morphology, bionomy and ecology of developmental stages of Central European Curculionids]. Abh. Senckenberg. Nat. Ges. 1964, 506, 1-335.

138. Volovnik, S.V. On the oviposition of weevils of the genus Lixus (Coleoptera, Curculionidae). Zool. Zhurnal 1994, 73, 49-54, (In Russian, Translated in Ent. Rev. 1995, 74, 115-120).

139. Volovnik, S.V. On Distribution and Ecology of Some Species of Cleonines (Coleoptera, Curculionidae): IV. Genus Lixus F., Subgenus Eulixus Reitt. Entomol. Obozr. 2007, 86, 521-529, (In Russian, Translated in Ent. Rev. 2008, 87, 840-847). [CrossRef]

140. Furth, D.G. Israel, a great biogeographic crossroads. Discovery 1975, 11, 2-13.

141. Bytinski-Salz, H. The Ethiopian element in the insect fauna of Israel. In Proceedings of the XI International Congress of Entomology, Vienna, Austria, 17-25 August 1960. 